\title{
AVALIAÇÃO FÍSICO-QUÍMICA, NUTRICIONAL E BIOLÓGICA DAS SILAGENS ÁCIDA, BIOLÓGICA E ENZIMÁTICA ELABORADAS COM DESCARTE E RESÍDUO DO BENEFICIAMENTO DA TILÁPIA DO NILO (Oreochromis niloticus)
}

\section{RICARDO BORGHESI}

Dissertação apresentada à Escola Superior de Agricultura "Luiz de Queiroz", Universidade de São Paulo, para obtenção do título de Mestre em Ciências, Área de Concentração: Ciência e Tecnologia de Alimentos.

P I R A C I C A B A

Estado de São Paulo - Brasil

Julho - 2004 


\title{
AVALIAÇÃO FÍSICO-QUÍMICA, NUTRICIONAL E BIOLÓGICA DAS SILAGENS ÁCIDA, BIOLÓGICA E ENZIMÁTICA ELABORADAS COM DESCARTE E RESÍDUO DO BENEFICIAMENTO DA TILÁPIA DO NILO (Oreochromis niloticus)
}

\section{RICARDO BORGHESI}

Zootecnista

Orientador: Prof ${ }^{\mathrm{a}}$. Dri ${ }^{\mathrm{a}}$. MARÍLIA OETTERER

\begin{abstract}
Dissertação apresentada à Escola Superior de Agricultura "Luiz de Queiroz", Universidade de São Paulo, para obtenção do título de Mestre em Ciências, Área de Concentração: Ciência e Tecnologia de Alimentos.
\end{abstract}

P I R A C I C A B A

Estado de São Paulo - Brasil

Julho - 2004 
Dados Internacionais de Catalogação na Publicação (CIP) DIVISÃO DE BIBLIOTECA E DOCUMENTAÇÃO - ESALQ/USP

\section{Borghesi, Ricardo}

Avaliação físico-química, nutricional e biológica das silagens ácida, biológica e enzimática elaboradas com descarte e resíduo do beneficiamento da Tilápia do Nilo (Oreochromis niloticus)

$96 \mathrm{p}$.

Dissertação (mestrado) - - Escola Superior de Agricultura Luiz de Queiroz, 2004. Bibliografia.

1. Aminoácidos 2. Avaliação nutricional para animal 3. Resíduos para animais 4. Tilápia-do-Nilo I. Título

CDD 664.94

"Permitida a cópia total ou parcial deste documento, desde que citada a fonte - O autor" 
Aos meu pais, João Carlos e Maria Helena, pela educação, confiança e estímulos constantes em todos os momentos da minha vida e à minha noiva Ana Clara pelo apoio, carinho e dedicação em todos esses anos que estamos juntos

"Aos meus avós José Severino Filho (in memorian) e Luiza Fornazzari Borghesi (in memorian)" 


\section{AGRADECIMENTOS}

A Deus, por sempre estar ao meu lado me protegendo e orientando;

Aos meus pais, pelo grande exemplo de vida, pela educação e apoio nas horas mais difíceis;

À minha noiva Ana Clara, que soube compreender, tolerar, amar e me apoiar nos momentos mais difíceis;

À Prof ${ }^{\mathrm{a}} \operatorname{Dr}^{\mathrm{a}}$ Marília Oetterer, pela orientação e amizade, tornando possível a elaboração deste trabalho;

A Fundação de Amparo à Pesquisa do Estado de São Paulo, pelo auxílio pesquisa que tornou possível a realização desta pesquisa;

À CAPES, pela bolsa concedida;

À minha prima, Márcia Regina Severino Bertarelli, pela amizade e pela disposição em ajudar sempre que necessário;

A todos do Laboratório de Pescado, Ivani, Roberta e Juliana, pela paciência e ajuda na condução do trabalho;

Aos professores Drs. José Eurico Possebon Cyrino, Marisa Aparecida Bismara Regitano d'Arce, Margarida Maria Barros Ferreira Lima e Carmen Josefina Contreras, pelas sugestões e auxílio nas correções;

Ao amigo, Leandro Portz, pela ajuda nas análises estatísticas, amizade sincera e pelo incentivo nos momentos mais difíceis;

Aos amigos Aelson Aloir Santana Brum e Lia Ferraz de Arruda, pela amizade e pelo apoio nos momentos de dificuldade;

Ao Prof. Dr. Luiz Edivaldo Pezzato, UNESP-Botucatu, por permitir o uso do laboratório para a realização do experimento; 
A todo pessoal do Laboratório AquaNutri, UNESP-Botucatu, Dario, Hamilton, Alexandre, Giovani, Jeisson, pelo auxílio na condução do trabalho;

À equipe da $\mathrm{CBO}$, na pessoa de Oneida Vasconcelos Vieira, pela condução das análises químicas;

À secretária da pós-graduação, Regina Lúcia Mello Lourenço, pela ajuda na condução dos procedimentos burocráticos do mestrado;

Um agradecimento sincero a todas as pessoas que, direta ou indiretamente contribuíram para a realização deste trabalho. 


\section{SUMÁRIO}

Página

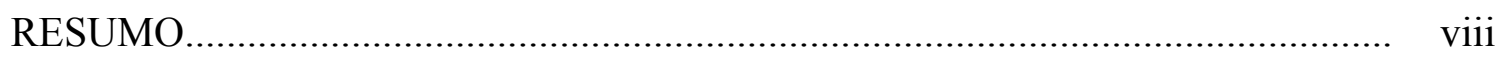

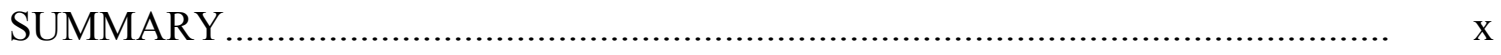

1 INTRODUÇÃO

2 REVISÃO DE LITERATURA.................................................................... 4

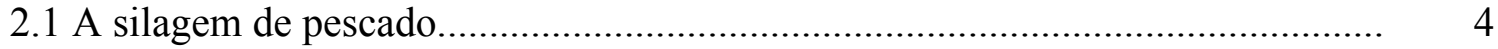

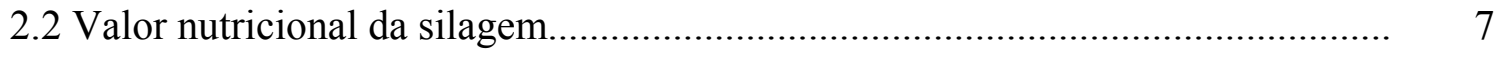

2.3 Alimentação de aves e suínos.................................................................. 9

2.4 Alimentação de organismos aquáticos....................................................... 11

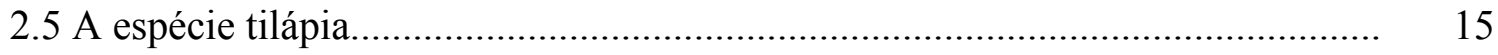

2.6 Digestibilidade, com especial referência a proteína e aminoácido...................... 16

3 CARACTERIZAÇÃO FÍSICO-QUÍMICA E NUTRICIONAL DE SILAGENS DE TILÁPIA DO NILO (Oreochromis niloticus)................................................. 20

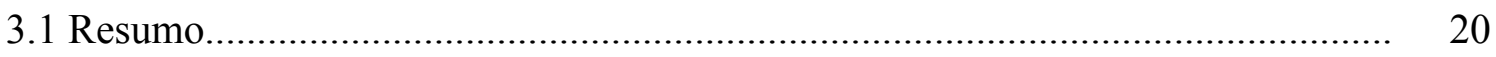

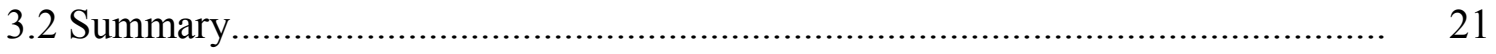

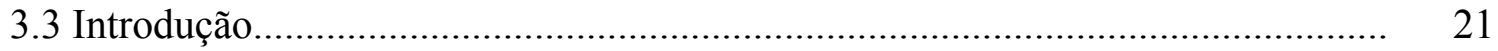

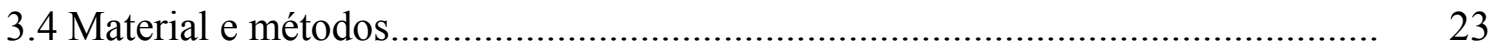

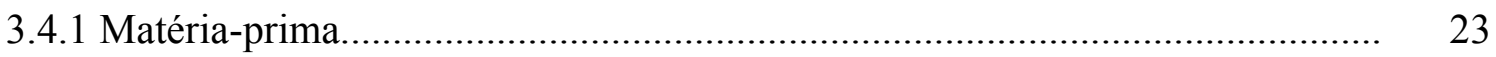

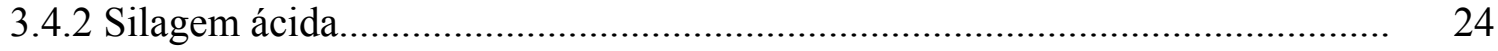

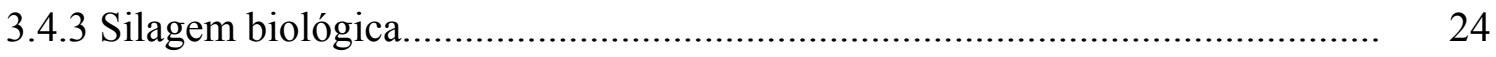

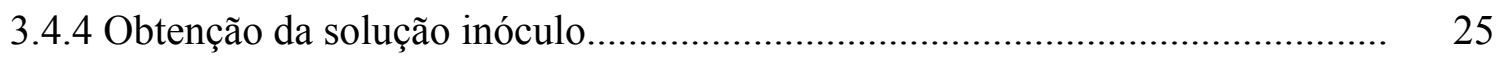

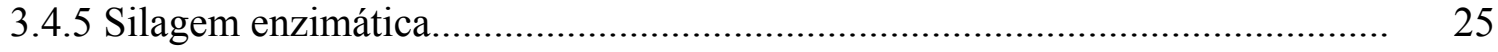

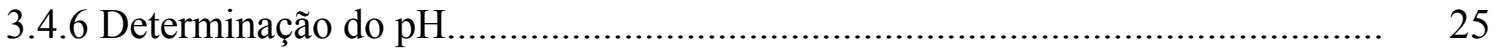


3.4.7 Análises químicas.................................................................................. 27

3.4.8 Análise dos aminoácidos............................................................................... 27

3.4.9 Determinação do escore químico de aminoácidos essenciais.............................. 27

3.4.10 Análise dos ácidos graxos..................................................................... 28

3.4.11 Análises estatísticas................................................................................ 28

3.5 Resultados e discussão............................................................................. 28

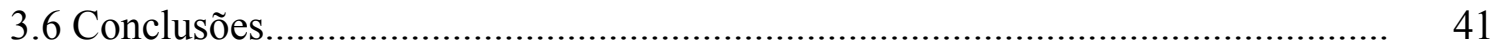

3.7 Referências Bibliográficas.......................................................................... 41

4 COEFICIENTE DE DIGESTIBILIDADE APARENTE DA ENERGIA E DOS NUTRIENTES DAS SILAGENS ÁCIDA, BIOLÓGICA E ENZIMÁTICA PELA TILÁPIA DO NILO (Oreochromis niloticus)......................................................... 51

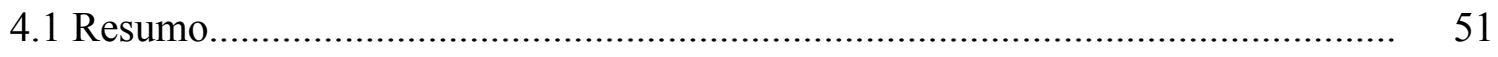

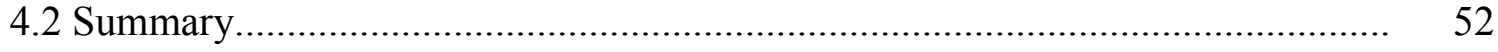

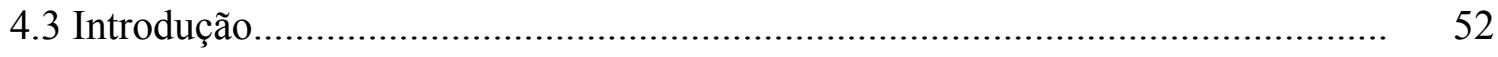

4.4 Material e métodos............................................................................... 55

4.4.1 Matéria-prima........................................................................................ 55

4.4.2 Silagem ácida.................................................................................. 55

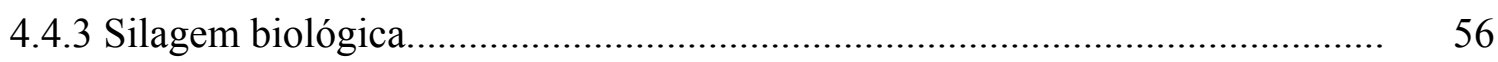

4.4.4 Obtenção da solução inóculo......................................................................... 56

4.4.5 Silagem enzimática.............................................................................. 56

4.4.6 Análises químicas.................................................................................. 57

4.4.7 Análise dos aminoácidos............................................................................ 57

4.4.8 Determinação do coeficiente de digestibilidade aparente.................................. 57

4.5 Resultados e discussão................................................................................ 60

4.6 Conclusões.............................................................................................

4.7 Referências Bibliográficas........................................................................... 71

5 CONCLUSÕES GERAIS ......................................................................... 79

REFERÊNCIAS BIBLIOGRÁFICAS................................................................... 81 


\title{
AVALIAÇÃO FÍSICO-QUÍMICA, NUTRICIONAL E BIOLÓGICA DAS SILAGENS ÁCIDA, BIOLÓGICA E ENZIMÁTICA ELABORADAS COM DESCARTE E RESÍDUO DO BENEFICIAMENTO DA TILÁPIA DO NILO
}

(Oreochromis niloticus)

\author{
Autor: RICARDO BORGHESI \\ Orientadora: Prof ${ }^{\mathrm{a}}$. Dr ${ }^{\mathrm{a}}$. MARÍLIA OETTERER
}

\section{RESUMO}

No Brasil e no mundo, a indústria relacionada à pesca gera grande quantidade de resíduo de alto valor biológico. Este material residual, devido a falta de um destino adequado, é considerado um problema sob o ponto de vista ambiental, de sanidade e de eficiência de produção. Com os objetivos de minimizar os problemas ambientais e melhorar a eficiência de produção da indústria do pescado, procedeu-se a elaboração e a caracterização físico-química e nutricional da silagem ácida (SA), silagem biológica (SB) e silagem enzimática (SE), utilizando como matéria-prima os descartes da piscicultura e o resíduo do beneficiamento da tilápia do Nilo (Oreochromis niloticus) (Experimento 1). As silagens SA, SB e SE apresentaram os valores (base na matéria seca) de: 25,$21 ; 34,58$ e 25,01 g/100g para a matéria seca, 54,25; 33,00 e 54,50 g/100g para a proteína bruta, 12,$45 ; 12,25$ e $12,17 \mathrm{~g} / 100 \mathrm{~g}$ para lipídios, 8,03; 7,33 e 8,58 g/100g para o cálcio e 4,71;2,86 e 4,85 g/100g para o fósforo, respectivamente. Entre os aminoácidos essenciais (AAE), a leucina $(3,50 ; 2,41$ e 3,31 g/100g para SA, SB e SE, respectivamente) e a lisina $(3,33 ; 2,41$ e 3,22 g/100g para SA, SB e SE, respectivamente) apresentaram-se em maior concentração. Com base no escore químico, todas as silagens 
apresentaram deficiência em triptofano, quando comparadas às exigências em AAE para a tilápia do Nilo, de acordo com o NRC (1993). Contudo, considerando-se como aminoácidos limitantes apenas os que estiverem 30\% abaixo das exigências mínimas para peixes, em geral, esses produtos não são deficientes em nenhum AAE. Em um segundo experimento, avaliou-se biologicamente as silagens elaboradas no experimento 1, através da determinação do coeficiente de digestibilidade aparente (CDA) da energia, nutrientes e aminoácidos. Foram encontrados valores de CDA de: 92,01; 89,09 e 93,66\% para proteína bruta, 86,$39 ; 84,53$ e $89,09 \%$ para energia bruta, 82,$52 ; 78,98$ e $82,96 \%$ para matéria seca, 81,$72 ; 73,99$ e $80,27 \%$ para cálcio e 77,$86 ; 79,21$ e $81,46 \%$ para o fósforo na SA, SB e SE, respectivamente. O CDA médio dos aminoácidos foi de: 91,83; 90,76 e $94,61 \%$ para SA, SB e SE, respectivamente. Os resultados obtidos para SA e SE foram, de maneira geral próximos e melhores que os obtidos para SB. Recomenda-se, com base nos resultados desta pesquisa, o uso da SA pela facilidade na sua elaboração. 


\title{
PHYSICAL-CHEMICAL, NUTRITIONAL AND BIOLOGICAL EVALUATION OF ACID, BIOLOGICAL AND ENZYMATIC SILAGE MADE FROM TRASH FISH AND FISH WASTE FROM THE PROCESSING OF NILE TILAPIA
}

(Oreochromis niloticus)

\author{
Author: RICARDO BORGHESI \\ Adviser: Prof ${ }^{\mathrm{a}}$. Dra ${ }^{\mathrm{a}}$. MARÍLIA OETTERER
}

\section{SUMMARY}

In Brazil and around the world, the fish-related industry produces a great amount of waster of high biological value. Due to the lack an adequate use, this residual material is considered a problem from the sanitary, environmental and production efficiency perspectives. With the objective of minimizing environmental problems and increasing fish production efficiency, the elaboration and the physical-chemical and nutritional characterization of the acid silage (AS), biological silage (BS) and enzymatic silage (ES) was performed with the use of trash fish and Nile tilapia (Oreochromis niloticus) processing waste (Experiment 1). The AS, BS, and ES values (dry matter basis) found were, respectively, 25.21; 34.58 and $25.01 \mathrm{~g} .100 \mathrm{~g}^{-1}$ of dry matter, 54.25; 33.00 and 54.50 g. $100 \mathrm{~g}^{-1}$ of crude protein, $12.45 ; 12.25$ and 12.17 g. $100 \mathrm{~g}^{-1}$ of lipids; $8.03,7.33$ and 8.58 g. $100 \mathrm{~g}^{-1}$ of calcium and $4.71 ; 2.86$ and $4.85 \mathrm{~g} .100 \mathrm{~g}^{-1}$ of phosphor. In

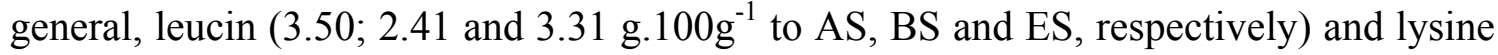
$\left(3.33 ; 2.41\right.$ and $3.22 \mathrm{~g} .100 \mathrm{~g}^{-1}$ to AS, BS and ES, respectively) were the essential amino acids (EAA) with the highest concentrations. According to their chemical score, all silages were tryptophan-deficient when compared to the EAA requirements for Nile 
tilapia according to the NRC (1993). However, considering that amino acids are only a limitation when less than $30 \%$ of the minimal requirements for fish in general, these products are not deficient in any EAA. In a second experiment, the silage produced in Experiment 1 was biologically evaluated by the determination of the apparent digestibility coefficient (ADC) for energy, nutrients and amino acids. The ADC values found were: crude protein, 92.01; 89.09 and 93.66\%; crude energy, 86.39; 84.53 and $89.09 \%$; dry matter, 82.52; 78.98 and 82.96\%; calcium, 81.72; 73.99 and 80.27\%; phosphor, 77.86; 79.21 and $81.46 \%$ of AS, BS and ES, respectively. The average amino acids ADC was $91.83 ; 90.76$ and $94.61 \%$ of AS, BS and ES, respectively. Based on the results of the experiments, we may conclude that all prepared silages are potentially viable for the use in balanced fish diets. It is recommended, the use of AS for the easiness in its elaboration. 


\section{INTRODUÇÃO}

Todos os anos milhares de toneladas de resíduo são produzidas e descartadas pelas unidades beneficiadoras de pescado; estas devido a pela falta de um destino adequado para este material, despejam-no no ambiente, gerando um sério problema de poluição ambiental.

Além do material residual que é descartado pela indústria, existe também aquele que é perdido mesmo antes de chegar às plantas processadoras devido ao manejo, transporte e armazenamento inadequados praticados durante e após a captura (Zahar et al., 2002).

A geração de subprodutos na indústria de alimentos, através da bioconversão, representa fonte potencial de rações e alimentos. No entanto, a procura por métodos e técnicas eficientes para o aproveitamento do resíduo é recente, não havendo no passado, preocupação com a eficiência na utilização deste, aceitando-se que as perdas, que podem superar a $60 \%$ do total capturado e/ou produzido, eram inevitáveis durante o processamento (Morais \& Martins, 1981).

Portanto, devido a valorização emergente do aproveitamento do resíduo do setor pesqueiro marinho e da piscicultura gerada pelas necessidades de gerenciamento ambiental, busca do desenvolvimento sustentável, redução de custos de produção do pescado brasileiro a ser ofertado para a comercialização e industrialização e ainda, o aumento dos benefícios da agroindústria do pescado cultivado, faz-se necessário o desenvolvimento de tecnologias que tenham o objetivo de aproveitar este material, rico em proteína e lipídios com conseqüente inserção deste na cadeia produtiva do pescado (Oetterer, 2002). 
Os resíduos do processamento industrial e os descartes são principalmente utilizados para a produção de farinha de pescado, que apesar de ser considerada uma fonte completa de nutrientes, exige altos investimentos para a sua fabricação e apresenta problemas com odor e efluentes (Disney et al., 1977; Kompiang, 1981).

Uma forma de minimizar os problemas ambientais gerados pela grande quantidade de resíduo de pescado é transformá-lo em um produto que possa ser incorporado, como ingrediente, em rações animais (Ristic et al., 2002). Uma alternativa viável seria destinar o resíduo para a fabricação da silagem de pescado, por ser um produto de fácil elaboração e que não exige alto investimento. O produto final é estável, com boa qualidade nutritiva e características antimicrobianas, podendo, portanto, ser de grande utilidade para a alimentação animal (Berenz, 1994).

O aproveitamento do resíduo deve ser imediato; assim que é escoado das mesas processadoras, deve-se separar as partes sólidas, homogeneizar e tratá-las com a mistura de ácidos escolhida (Oetterer, 2002). Este procedimento é de extrema importância, pois as condições da matéria-prima utilizada para a elaboração da silagem, estão diretamente relacionadas com a qualidade do produto final (FAO, 2003a).

A principal característica das rações para a aqüicultura é o elevado teor protéico; a maior participação de fontes de proteína eleva o custo total da ração. A farinha de peixe tem sido, durante anos, a fonte protéica de origem animal mais utilizada em dietas balanceadas para peixes, sendo considerada indispensável para a obtenção de um crescimento adequado, devido ao teor e qualidade da sua proteína, além de atuar como palatabilizante. (Furuya, 2000; Furuya et al., 2001; Vidotti, 2001).

Para New \& Csavas (1995), havendo o aumento da demanda por alimentos aquáticos, o preço da farinha de peixe poderá se elevar muito, e ao mesmo tempo o fornecimento declinar. Portanto, em função do alto custo e possível escassez no mercado mundial, diversas pesquisas vêm sendo realizadas na busca por um substituto adequado para a farinha de peixe, quanto aos aspectos nutricionais e de custo (Chong et al., 2002; Fontaínha-Fernandes et al., 1999; Guzmán \& Viana, 1998; Portz, 2001a, 2001b; Stone et al., 2000). 
Para se avaliar corretamente o potencial de um ingrediente para ser utilizado em uma ração balanceada, além de sua composição química, é de fundamental importância que se determine sua digestibilidade, já que um ingrediente pode apresentar altos níveis de um nutriente e este ser pouco absorvido (Furuya, 2000).

Muitos autores acreditam que a silagem tenha elevado potencial para a utilização na aqüicultura, devido a semelhança desta com a matéria-prima, fornecendo proteínas de boa qualidade, alta digestibilidade e com baixo custo (Fagbenro \& Jauncey, 1995a; Heras et al., 1994; Honczaryk \& Maeda, 1998; Vidotti, 2001; Vidotti et al., 2003).

De acordo com Morales-Ulloa (1994) e Valério (1994), a silagem de pescado não deve ser vista como um produto competidor com a farinha de peixe, mas sim como mais uma alternativa na utilização das fontes disponíveis.

Com o aumento do número de indústrias beneficiadoras de tilápias, o resíduo, gerado com esta atividade, tornou-se um sério problema para os produtores. Em muitos casos, o processo de ensilagem poderia ser uma solução, pois a obtenção da silagem é simples e de baixo custo, além de agregar valor ao produto, baixando os custos de produção (Morales-Ulloa, 1994; Valério, 1994; Vidotti, 2001).

Os efeitos desta iniciativa ambiental e econômica, poderão ser observadas no futuro, com a geração de empregos diretos e indiretos, como também o aumento da produtividade da agroindústria, pois nosso país convive passivamente com a crise ambiental, provocada também pela poluição dos resíduos de pescado, que são destinados diariamente aos lixões nas grandes cidades, a custos elevados para a sociedade, isto quando não são jogados diretamente no ambiente aquático, de onde foram capturados (Espíndola Filho, 1999). 


\section{REVISÃO DE LITERATURA}

\subsection{A silagem de pescado}

A ensilagem de resíduos de pescado é uma técnica antiga de preservação da matéria orgânica (Hammoumi et al., 1998). A metodologia para preservação do resíduo de pescado foi adaptada por Edin na década de 30, a partir de um método patenteado por Virtanen na década de 20, que utilizava os ácidos sulfúrico e clorídrico para preservação de forragens (Raa \& Gilberg, 1982).

Desde a década de 40, a silagem tem sido produzida em muitos países, como Canadá, Inglaterra, Noruega e Alemanha, mas foi, preferencialmente, na Dinamarca, Polônia e Noruega que o processamento da silagem prosseguiu em escala comercial (Sales, 1995).

A preservação do material ensilado é dada pela redução do $\mathrm{pH}$, através da adição de ácidos orgânicos e/ou minerais (silagem ácida), pela adição de microrganismos produtores de ácido lático (silagem biológica) ou combinação dos dois métodos. Além de prevenir contra a ação microbiana e não atrair insetos, o abaixamento do $\mathrm{pH}$ propicia a ação das enzimas naturalmente presentes no pescado e/ou adicionadas (silagem enzimática) que são responsáveis pela hidrólise protéica (Kompiang, 1981; Nunes, 1999; Rivero \& Viana, 1996; Tatterson \& Windsor, 1974; Vizcarra-Magaña et al., 1999; Zahar et al., 2002).

O processo de ensilagem apresenta muitas vantagens sobre a produção da farinha de peixe, pois a tecnologia é relativamente simples, o equipamento essencial é de baixo custo e a escala de produção é variável. O produto final é estável, apresenta-se com consistência semi-líquida e possui bom valor nutricional, podendo ser usado como 
ingrediente em rações animais (Coello et al., 2000; Espíndola Filho, 1999; Jackson et al., 1984a; Martin \& Bemister, 1994; Oetterer, 1994; Ottati, 1990; Tatterson \& Windsor, 1974).

Kompiang (1981), aponta as seguintes vantagens para a produção de silagem sobre a produção de farinha de pescado: tecnologia simples, independe de escala, não necessita de grande capital, apresenta reduzidos problemas com odor e efluentes, independe do clima, pode ser produzida a bordo dos barcos, o processo é rápido em regiões de clima tropical e o produto pode ser utilizado no local. No entanto as desvantagens também são consideradas pelo autor: é um produto volumoso, de difícil transporte e estocagem e em alguns casos, devido ao alto teor de gordura dos peixes, o produto final pode ser inferior.

A liquefação que ocorre durante o processo de ensilagem é o resultado da hidrólise enzimática. Presume-se também que a autólise em silagens preparadas com o pescado inteiro ocorre, principalmente, devido as enzimas das vísceras que são distribuídas pela massa do peixe após a moagem. A liquefação da silagem é marcadamente favorecida em meio ácido e em temperaturas acima da média ambiente (Oetterer, 1994).

Avaliando o efeito do pré-aquecimento e da adição de ácidos fosfórico e cítrico na qualidade bioquímica de silagens químicas de pescado, Guzmán \& Viana (1998) e Viana et al. (1996, 1999), notaram que a mistura de ácido cítrico e fosfórico oferece uma boa alternativa para elaborar silagem, a partir do resíduo pesqueiro. E ainda, o aquecimento prévio ao processamento da silagem aumenta a conservação do produto.

A mistura do ácido sulfúrico com ácido fórmico ou com o ácido fosfórico na proporção de $3: 1$, ambos a 3,5\% (v/p), mostrou ser eficiente na produção da silagem química. Esta possibilidade de substituição do ácido fórmico pelo ácido fosfórico é interessante pois permite a diminuição no custo de produção desta silagem (Espíndola Filho, 1999).

A fermentação microbiana pode ocorrer no pescado, desde que haja uma fonte de carboidratos adicionada à biomassa. Assim, as bactérias produtoras de ácido lático propiciarão a preservação através da produção de ácido lático e conseqüente 
abaixamento do $\mathrm{pH}$ (Oetterer, 1994), inibindo o crescimento de bactérias como Staphylococcus, Escherichia, Serratia, Enterobacter, Citrosacter, Achromobacter e Pseudomonas (Dapkevicius et al., 2000; Samuels et al., 1991; Wyk \& Hydenryck, 1985). Além da acidez, acredita-se que a habilidade de certas bactérias ácido láticas em produzir compostos antibacterianos, chamados bacteriocinas, colaboram na inibição do crescimento de microrganismos patogênicos (Borrensen, 1990; Lindgren \& Pleje, 1983).

Zahar et al. (2002), estudaram o efeito da temperatura, anaerobiose e agitação da massa, na produção de silagens biológicas, utilizando como fonte de carboidrato o melaço de cana. Os autores concluíram que a fermentação natural é acelerada, se conduzida em temperatura ambiente $\left(25 \pm 2^{\circ} \mathrm{C}\right)$, recipientes fechados e com agitação diária da massa.

Foram preparadas por Vidotti et al. (2003), silagens biológicas e ácidas, a partir de diferentes matérias-primas. Os autores concluíram que além de serem viáveis, os processos utilizados para a preservação do resíduo de pescado, mantêm a qualidade protéica dos produtos.

Valério (1994) elaborou silagens enzimáticas a partir do resíduo do processamento de sardinhas, como alternativa ao processo tradicional, e concluiu que o uso das enzimas protease e pepsina, produziram silagens com composição semelhante à da matéria-prima.

Berenz (1994), preparou silagens biológicas utilizando 5\% de iogurte e 10\% de melaço de cana, obtendo um produto com 63,32\% de umidade e 18,46\% de proteína bruta (base úmida). $\mathrm{O}$ autor testou o produto obtido na alimentação de frangos de corte e concluiu que a silagem é uma fonte protéico-energética, possível de ser utilizada em rações, sem perda do desempenho e da qualidade da carcaça.

De acordo com vários autores (Goddard \& Al-Yahyai, 2001; Kompiang, 1981; Morales-Ulloa, 1994; Morales-Ulloa \& Oetterer, 1995, 1997; Valério, 1994), a silagem produzida com uma mistura de ácidos fórmico e propiônico, na proporção de 1:1 e adição de 1,5 a 3,0\% (v/p) em relação à massa é recomendada, e o produto obtido é estável e livre de microrganismos patógenos. 


\subsection{Valor nutricional da silagem}

Apesar das alterações nas estruturas física e química do peixe, o valor nutricional da silagem é semelhante ao material que the deu origem, variando, consideravelmente, com o tipo de matéria-prima empregada, particularmente quanto ao teor de lipídios (Disney et al., 1977; Haard et al., 1985; Kompiang 1981).

Durante o armazenamento prolongado, grande número de aminoácidos livres está presente na silagem devido a atividade das enzimas endógenas. A hidrólise prolongada, no entanto, pode resultar numa redução do valor nutricional da silagem (Viana et al.,1999). Para evitar a hidrólise excessiva durante estocagem prolongada, as enzimas presentes no pescado podem ser inativadas pelo aquecimento da matéria-prima por 5 minutos, a $60^{\circ} \mathrm{C}$, antes da ensilagem, resultando na redução de $15 \%$ no nível de aminoácidos livres, após 90 dias, quando comparada com uma silagem que não foi aquecida (Viana et al., 1996).

De acordo com Oetterer (1999) e Raa \& Njaa (1989), o valor nutricional da silagem está na digestibilidade protéica elevada, que deve ser preservada evitando-se estocagem prolongada e, portanto, hidrólise excessiva.

Vários autores (Goddard \& Al-Yahyai, 2001; Stone et al., 1989; Stone \& Hardy, 1986; Viana et al., 1996, 1999), citam que limitando-se a hidrólise protéica, o valor nutricional do produto final do processo de ensilagem é superior, quando comparado a um material excessivamente hidrolisado, já que os peptídeos de cadeia curta são melhor absorvidos que os aminoácidos livres.

Segundo Espe et al. (1989), uma explicação provável para a redução do valor nutricional, pode ser o fato dos aminoácidos livres serem rapidamente desviados da síntese protéica e entrarem na rota catabólica. Os mesmos autores citam que os aminoácidos livres estão mais disponíveis para serem utilizados como fonte de energia do que as proteínas intactas.

Os aminoácidos livres, em presença de hidroxilas provenientes do açúcar, entram na reação de Maillard, resultando em diminuição do valor nutricional da silagem (Fagbenro, 1994; Fagbenro \& Jauncey, 1998; Johnson et al., 1985). 
De acordo com Stone \& Hardy (1986), altos níveis de aminoácidos livres na dieta interferem no mecanismo de absorção de aminoácidos e peptídeos de cadeia curta. Os peptídeos de cadeia curta quando absorvidos reduzem as flutuações no nível de aminoácidos no plasma e retornam disponíveis para a síntese protéica por períodos mais longos do que os aminoácidos livres.

Outro fator importante na deterioração da qualidade das silagens armazenadas por longos períodos, é o processo de oxidação lipídica, resultando em alterações de sabor, cor, textura, valor nutricional e produção de componentes tóxicos (Sales, 1995).

Kompiang (1981), destaca que a eficiência de conversão se torna baixa e o valor nutricional é também afetado, negativamente, com o aumento do tempo de armazenamento. Para o autor há uma relação direta do escurecimento provocado por reações dos lipídios com a perda do valor nutritivo.

Disney et al. (1977), citam que as mudanças que ocorrem com os lipídios durante o armazenamento da silagem são o aumento do conteúdo de ácidos graxos livres, indicando hidrólise de glicerídeos e alterações oxidativas que levam ao escurecimento. Sales (1995), relata que quando as proteínas são expostas a lipídios peroxidados, uma considerável porção destes complexa-se com proteínas através de associações e/ou ligações de hidrogênio, causando perda do valor nutritivo.

A oxidação de lipídios pode causar a formação de peróxidos, que podem complexar as proteínas, através de ligações físicas e covalentes (Nelson \& Cox, 2000). Ligações covalentes entre produtos oxidados e proteínas podem destruir aminoácidos como triptofano, oxidar a metionina e ligar a lisina a outros compostos tornando estes aminoácidos indisponíveis (Nelson \& Cox, 2000).

Tocher et al. (1997), demonstraram que silagens preparadas utilizando tecidos que compõem o sistema nervoso de peixes são ricos em fosfolipídios e triglicerídeos dependendo da espécie e do tecido (olho, cérebro). Todos continham altos níveis de docosahexaenóico e alta proporção de docosahexaenóico : eicosapentaenóico.

De acordo com Sales (1995) e Dapkevicius et al. (2000), a formação de aminas biogênicas pode também ser um problema, se a silagem de pescado for produzida a partir de uma matéria-prima alterada com altos níveis de aminoácidos livres. 
Espíndola Filho et al. (1998) procederam ao processamento de silagem de resíduos de peixes, camarões e bivalves, e obtiveram um concentrado protéico-mineral para ser utilizado em rações animais, contendo 10\% de umidade, 50\% de proteína, 8\% de lipídios e $20 \%$ de cinza, sendo desta, $5 \%$ de cálcio, $2 \%$ de fósforo e outros minerais em menores proporções.

\subsection{Alimentação de aves e suínos}

O produto final do processo de ensilagem pode ser considerado como uma importante fonte alternativa de proteína na alimentação animal, principalmente em situações nas quais a produção da farinha de peixe não é possível e/ou o custo desta fonte protéica é muito alto (Disney et al., 1977; Hussain \& Offer, 1987).

Em escala comercial, a silagem de pescado é produzida na Polônia e Dinamarca desde os anos 60 e utilizada na alimentação de aves e suínos, incorporada a rações como complemento protéico e compondo rações destinadas a "pets" e uso na piscicultura (Oetterer, 2002).

A produção de ração aumenta ano após ano, e novas fontes protéicas são necessárias, especialmente em países onde proteínas de origem animal são poucas para suprir as necessidades. Os resíduos sólidos das indústrias de alimento são uma interessante fonte protéica para ser incorporada na formulação de rações, representando um ingrediente com alto teor protéico (Hammoumi et al., 1998).

A idéia de utilizar a silagem de pescado na alimentação animal, como ingrediente protéico em rações, deve-se ao fato desta apresentar composição semelhante à da matéria-prima, alta digestibilidade e presença integral dos aminoácidos constituintes do pescado (Oetterer, 2002).

Johnson et al. (1985), avaliando o valor nutricional de dois tipos de silagem para galinhas, constataram que a incorporação do produto final da silagem em dietas balanceadas não causou diminuição no crescimento e nem diferenças no sabor da carne, quando comparada a aves alimentadas com dietas a base de farinha de soja e farinha de peixe. 
Hammoumi et al. (1998) formularam dietas a base de ensilado de pescado incorporado com farelo de trigo e cevada e compararam com uma dieta comercial (controle) para frangos de corte. Os autores concluíram que todas as dietas testadas propiciaram similar ganho de peso das aves, indicando que a silagem de pescado tem um grande potencial para ser utilizada em dietas para frangos de corte.

De acordo com Raa \& Gilberg (1982) o fator limitante para a inclusão da silagem em dietas para aves e suínos é a fração lipídica desta. Segundo estes autores para evitar problemas de "off flavor", o teor de óleo de pescado não deve exceder a $1 \%$ com base na matéria seca da dieta.

Green et al. (1988), avaliaram a estabilidade do óleo de peixe e o valor nutricional da silagem de peixe no crescimento de suínos. Foram utilizados animais resultantes do cruzamento Landrace x (Landrace x Large White) na faixa de 25 a $55 \mathrm{~kg}$ e quatro dietas isoprotéicas e isoenergéticas, com suplementação mineral, e com 0 (controle a base de farelo de soja e milho), 50, 100 e $150 \mathrm{~g}$ de silagem $/ \mathrm{kg}$. Os autores constataram que os animais alimentados com dietas que continham silagem de peixe cresceram mais rápido, sendo a quantidade de $100 \mathrm{~g}$ de silagem $/ \mathrm{kg}$ de matéria seca a que proporcionou o melhor desempenho (conversão alimentar igual a 1,96). Não foram observadas diferenças na composição da carcaça.

Com o propósito de determinar as contribuições da silagem de peixe no desempenho de leitões de 8 a $12 \mathrm{~kg}$ de peso vivo, Batterham et al. (1980), utilizaram seis níveis de silagem, $0,3,6,9,12,15 \%$ em substituição ao milho e ao farelo de soja. Os autores verificaram que o ganho de peso diário e a conversão alimentar aumentaram, linearmente, com o aumento do nível de silagem na ração, tendo sido observada uma exigência estimada de $6 \%$ para ganho de peso diário e conversão alimentar respectivamente, não tendo sido verificado efeito dos níveis de silagem no consumo de ração.

Green (1984), realizando trabalho com suínos, com o propósito de determinar o nível de silagem de peixe mais adequado para rações contendo $13 \%$ de proteína bruta para a fase de terminação de suínos, verificou que não houve diferença significativa $(P>0,05)$ entre os tratamentos, com suplementação de 5 e $10 \%$ de silagem de peixe, para 
o ganho de peso médio e nível de uréia no soro sangüíneo dos animais. Porém, para a conversão alimentar, foi verificada diferença significativa $(\mathrm{P}<0,05)$ entre os tratamentos, indicando uma melhora nutricional quando os animais eram tratados com rações com adição de $5 \%$ de silagem na base protéica. O mesmo autor constatou que a suplementação de silagem de peixe, com níveis acima de $10 \%$, nas rações a base de milho e farelo de soja, contendo $14 \%$ de proteína bruta, utilizadas em leitões, não ofereceram melhorias nos resultados de ganho de peso e conversão alimentar.

Sales (1995) com o objetivo de determinar o melhor nível de inclusão de silagem na dieta de suínos nas fases de crescimento e terminação, utilizou dietas com 0 (dieta controle a base de farelo de soja e milho), 5, 10 e 15\% de silagem. Os resultados demonstraram que o nível ideal de complementação com a silagem para a obtenção de maior valor nutricional foram as dietas contendo $5 \%$ de silagem de pescado para os suínos nas fases de crescimento e terminação.

\subsection{Alimentação de organismos aquáticos}

A elaboração de silagens a partir de resíduos da comercialização ou do processamento do pescado, visando sua utilização como ingrediente em rações para a aqüicultura, tem sido, nos últimos tempos, amplamente estudada. Muitos autores acreditam que devido à semelhança desta fonte protéica com a matéria-prima, a silagem tenha elevado potencial para a utilização na aqüicultura. Outros se apóiam no baixo custo, principalmente quando comparada à farinha de peixe (Das et al., 1993; Disney et al., 1977; Fagbenro, 1994; Fagbenro et al., 1994, Fagbenro \& Jauncey, 1995a, 1995b; Fagbenro \& Bello-Olusoji, 1997; Goddard \& Al-Yahyai, 2001; Neethiselvan et al, 2001; Vidotti et al., 2003).

Maia et al. (1998), abordam uma outra forma de utilização da silagem de peixe em rações para a aqüicultura. Estes autores caracterizaram a fração lipídica de silagens de resíduos de tilápia e concluíram que o óleo obtido do processo de silagem constitui-se numa fonte de lipídios de alta qualidade e baixo custo. 
Honczaryk \& Maeda (1998), avaliaram o crescimento do pirarucu (Arapaimas gigas), peixe carnívoro de grande importância na região amazônica, com dietas à base de silagem biológica, elaborada com resíduos da filetagem da piramutaba (Brachyplatystoma vaillantii). As dietas à base de ensilado proporcionaram bom crescimento e melhores características de carcaça quando comparadas com dietas à base de peixe picado.

Ximenes Carneiro (1991), alimentou alevinos de tambaqui (Colossoma macropomum) com dietas à base de silagem biológica de tilápia e conclui que é viável sua utilização como alternativa às farinhas de carne e ossos e de peixe. A composição dos peixes alimentados com ração à base de ensilado apresentou maiores níveis de cálcio e fósforo.

Goddard \& Al-Yahyai (2001), testando a digestibilidade da silagem ácida de sardinha e da farinha de peixe na alimentação da tilápia do Nilo (Oreochromis niloticus) não encontraram diferenças significativas entre os ingredientes testados, mostrando o potencial do uso da silagem de pescado como substituto parcial da farinha de peixe.

Estudando o uso da silagem de pescado na alimentação do salmão (Salmo salar), Jackson et al. (1984b), não encontraram diferenças significativas no crescimento, consumo alimentar e conversão alimentar, entre as dietas que continham a silagem e a dieta comercial, utilizada como dieta controle.

Dietas contendo silagens biológicas de tilápia, parcialmente desidratadas através da mistura com farelo de soja, com as farinhas de vísceras, de pena hidrolisada ou carne e ossos, foram avaliadas na alimentação da tilápia do Nilo (Oreochromis niloticus) e comparadas com uma dieta controle contendo a farinha de peixe e o farelo de soja como principais fontes protéicas. Nenhuma diferença foi encontrada no crescimento, digestibilidade, conteúdo de hemoglobina e hematócritos, conversão alimentar e taxa de eficiência protéica (Fagbenro, 1994).

Fagbenro \& Jauncey (1995b), estudaram o valor nutricional de dietas contendo a silagem biológica de tilápia parcialmente desidratada com diversos subprodutos, na alimentação do bagre africano (Clarias gariepinus). Os autores encontraram coeficientes de digestibilidade aparente para a proteína bruta entre 79,4 e 87,2\%. 
Fagbenro \& Jauncey (1998), utilizaram dietas úmidas para a tilápia do Nilo (Oreochromis niloticus), compostas de silagem biológica de tilápia misturada com diferentes ingredientes protéicos (farinha de vísceras ou farelo de soja e farinha de penas hidrolisadas ou farinha de peixe). Estes autores encontraram valores elevados para os coeficientes de digestibilidade aparente da proteína (entre 83,5 e 86,6\%), da energia bruta (entre 80,6 e $84,8 \%$ ) e matéria seca (entre 82,4 e $85,9 \%$ ).

Com o objetivo de estudar a utilização de silagens de peixe parcialmente desidratadas, como fontes alternativas de proteína na alimentação do pacu (Piaractus mesopotamicus), Vidotti (2001), encontrou valores de digestibilidade protéica e retenção protéica maiores que os obtidos por uma dieta controle, que continha a farinha de peixe como principal fonte protéica, indicando o potencial da silagem como substituto parcial da farinha de peixe em dietas para o pacu.

Hossain et al. (1997), determinaram o coeficiente de digestibilidade aparente de várias fontes protéicas de origem animal e vegetal para a carpa indiana (Labeo rohita). Este estudo mostrou que as silagens ácidas de pescado marinho, produzidas com ácido fórmico ou sulfúrico e parcialmente desidratadas com farinha de trigo, apresentaram os melhores coeficientes de digestibilidade aparente da proteína bruta (88,08 e 85,11\%, para as silagens com ácido fórmico e com ácido sulfúrico, respectivamente), concluindo que, do ponto de vista da digestibilidade, a silagem de pescado pode ser eficientemente utilizada como fonte protéica para alimentação da carpa indiana.

Estudando o coeficiente de digestibilidade aparente da proteína e dos aminoácidos essenciais da silagem biológica composta de cabeças de camarão, destinadas a alimentação do bagre africano (Clarias gariepinus), Fagbenro \& BelloOlusoji (1997), concluíram, baseados nos resultado deste parâmetro, que a silagem biológica se apresenta como uma boa alternativa de ingrediente protéico para esta espécie.

Utilizando diferentes aglutinantes em dietas úmidas para a tilápia do Nilo, contendo 50\% de silagem biológica de tilápia, Fagbenro \& Jauncey (1995a), obtiveram 
altos valores de digestibilidade para a proteína, lipídios e matéria seca, com exceção da dieta que continha o aglutinante goma-guar.

Segundo Gonçalves et al. (1989), para as enguias (Anguilla sp.), de grande importância em toda a Europa, o custo com alimentação representa cerca de $50 \%$. Portanto, a formulação de uma dieta econômica e nutritiva é de grande necessidade. Sendo assim, estes autores estudaram o uso da silagem na formulação de dietas para as enguias e constataram que as dietas contendo silagem proporcionaram melhor conversão alimentar e melhor ganho de peso, além de serem mais atrativas em relação à dieta controle, constituída de farinha de peixe e de carne como fontes protéicas.

Para o abalone (Haliotis fulgens), o alimento natural é uma microalga. Nos Estados Unidos, esta microalga é usada como o principal alimento para esta espécie. Dietas comerciais são produzidas somente no Japão e Nova Zelândia, mas o alto custo as torna inconvenientes. Dessa forma, o desenvolvimento de dietas artificiais é necessário, preferencialmente com um baixo custo. Com base nisto, Viana et al. (1994), Viana et al., 1996; Guzmán \& Viana, 1998; Viana et al., 1999, avaliaram a utilização da silagem ácida como um alimento alternativo. $\mathrm{O}$ uso da silagem ácida de pescado é uma fonte protéica alternativa de baixo custo para dietas de abalone, tornando seu cultivo economicamente viável e proporcionando maior crescimento quando comparado com a microalga natural.

Fagbenro et al. (1994), estudando o valor nutricional de dietas contendo silagem biológica de pescado parcialmente desidratadas pela adição de farelo de soja, resíduo de aves ou farinha de carne e ossos, constataram que não houve diferenças significativas nos parâmetros de desempenho e de utilização da proteína quando comparadas à dieta composta por farinha de peixe. $\mathrm{O}$ experimento mostrou que estas dietas, principalmente a composta por silagem e farelo de soja, podem ser utilizadas na alimentação de tilápias, Oreochromis niloticus (onívora) e bagre Africano Clarias gariepinus (carnívoro), sem que o desempenho, a utilização da proteína e a composição da carcaça sejam afetados.

Heras et al. (1994), relataram que salmões (Salmo salar) alimentados com silagem ácida, preparada com resíduos de dogfish (Squalus acanthias), apresentaram 
bom ganho de peso, conversão alimentar e taxa de eficiência protéica, quando comparadas a uma dieta controle contendo como principal fonte protéica a farinha de arenque. A análise sensorial dos filés não demonstrou diferenças significativas no sabor da carne.

Avaliando o uso de dietas a base de ensilado biológico de pescado no desempenho do Etroplus suratensis, Neethiselvan et al. (2001), não observaram diferenças quando comparadas com dietas a base de farinha de peixe.

Trutas arco-íris (Onchorynchus mykiss) tiveram maior ganho de peso, taxa de eficiência protéica e digestibilidade aparente, quando foram alimentadas com silagens ácidas, nas quais a autólise durou de 3 a 7 dias, do que quando alimentadas com silagens ácidas obtidas após autólise de 42 dias (Stone et al., 1989).

\subsection{A espécie tilápia}

As tilápias são ciclídeos originários do continente africano e apresentam produção concentrada principalmente em regiões de clima tropical e subtropical (Popma \& Masser, 1999; El-Sayed, 1999). São reconhecidas mais de 70 espécies de tilápias, sendo três os principais gêneros de importância comercial: Oreochromis spp., Sarotherodon spp. e Tilapia spp. (Kubitza, 2000; Popma \& Lovshin, 1996).

Destes três gêneros, o de maior destaque na aqüicultura mundial é o gênero Oreochromis spp. (Kubitza, 2000; Popma \& Masser,1999). As espécies de tilápias foram introduzidas fora do continente africano na década de 30, expandindo-se rapidamente pelo sudeste asiático e sul do Pacífico, Europa e sul dos Estados Unidos (Hildsorf, 1995).

Atualmente, as tilápias constituem a segunda espécie de peixes mais produzidos no mundo, com uma produção estimada em 1265780 toneladas em 2000 (FAO, 2003b).

Introduzida no Brasil em 1971, a tilápia do Nilo (Oreochromis niloticus) (Mainardes-Pinto et al., 1989), apresentou produção de 35000 toneladas em 1998, sendo assim, a espécie de pescado de água doce mais cultivada no Brasil (BRASIL, 2002). 
A tilápia é considerada uma das espécies mais promissoras para a aqüicultura devido a sua rusticidade, rápido crescimento e pelo hábito alimentar onívoro, consumindo ração logo após o início da alimentação exógena (Lovshin, 1998; Lovshin \& Cyrino, 1998; Furuya, 2000).

A carne da tilápia possui boas características organolépticas. De acordo com Chambers IV \& Robel (1993), este peixe apresenta a carne sem espinhos intramusculares, de cor branca, textura firme, aspecto fibroso e suculento e sabor apreciável. Tem um rendimento em filé de, aproximadamente, $33 \%$ e a comercialização é feita quando os espécimens atingem de 350 a 1000 gramas, dependendo da sua utilização (Tachibana, 2002).

As tilápias têm a característica de utilizar eficientemente alimentos de origem vegetal (Wohlfarth \& Hulata, 1981), devido a adaptações morfológicas e fisiológicas, tais como, dentes faringeanos, $\mathrm{pH}$ estomacal ácido (abaixo de 2) e intestino longo (ao menos seis vezes o tamanho do peixe) (Maina et al., 2002; Popma \& Masser,1999).

A tilápia pode resistir a um teor de até $0,5 \mathrm{mg} / \mathrm{L}$ de oxigênio dissolvido na água (Tachibana, 2002); o pH da água pode variar de 5 a 10 e tolera águas salobras e altas concentrações de amônia (Popma \& Masser, 1999). Apresenta ainda conforto térmico entre 27 e $32^{\circ} \mathrm{C}$ (Kubitza, 2000).

$\mathrm{Na}$ produção de tilápias é preconizado o cultivo somente de machos (monossexo), para evitar perdas de produtividade (Furuya, 2000), já que as fêmeas podem apresentar uma taxa de crescimento até cinco vezes menor, dependendo do manejo adotado. Para a obtenção de populações monossexo, é empregado o método de reversão sexual das larvas, fazendo-se uso de rações contendo hormônios masculinizantes (Varadaraj et al., 1994).

\subsection{Digestibilidade, com referência especial a proteína e aminoácido}

A digestibilidade é descrita como a fração do nutriente ou energia do alimento consumido que é digerido e absorvido e que, portanto, não é excretado nas fezes (NRC, 1993; De Silva \& Anderson, 1995). 
De acordo com Furuya (2001) e Furuya et al. (2001) a determinação da digestibilidade tem sido uma das principais ferramentas para a avaliação da qualidade de uma dieta ou ingrediente, indicando seu valor nutricional, e permitindo a obtenção dos níveis de nutrientes não digeridos que irão compor grande parte dos resíduos acumulados no meio aquático.

Se os alimentos para os peixes forem bem avaliados quanto à sua digestibilidade, teremos rações econômicas do ponto de vista de aproveitamento de nutrientes e ecologicamente corretas do ponto de vista ambiental, pois hoje existe uma forte preocupação, pelas autoridades governamentais, a respeito da preservação dos mananciais, onde a atividade da aqüicultura está envolvida diretamente (Portz, 2001b).

O valor nutricional de um alimento deve não somente ser baseado na sua composição química, mas também na quantidade de nutrientes ou energia que o peixe pode absorver e conseqüentemente utilizar, uma vez que um alimento pode apresentar elevado conteúdo de um nutriente de pouca importância biológica (NRC, 1993; Higuera, 1987; Furuya, 2000).

As diversas fontes protéicas disponíveis no mercado para formulação das rações não possuem os mesmos valores nutricionais e níveis de aminoácidos exigidos pelos peixes, tanto quantitativamente quanto qualitativamente (Cyrino, 2000). Visto isso, a avaliação de um ingrediente protéico deve ser feita com base na composição e principalmente na digestibilidade dos aminoácidos nele presentes (Portz, 2001b).

O conhecimento da digestibilidade de um nutriente é de suma importância para a condução de pesquisas sobre exigências nutricionais, avaliação do potencial de um ingrediente para inclusão em uma dieta, desenvolvimento de dietas de baixo custo e também de dietas que minimizem o impacto ambiental, devido a descarga de nutrientes não absorvidos, principalmente nitrogênio e fósforo nos efluentes (Allan et al., 2000; Vandenberg \& De La Noüe, 2001; Chong et al., 2002; Sales \& Britz, 2003)

Segundo Furuya (2000), ainda que existam diversos trabalhos com o objetivo de determinar a digestibilidade protéica, existem poucas referências sobre a digestibilidade dos aminoácidos dos principais ingredientes utilizados. $\mathrm{O}$ mesmo autor cita que a digestibilidade dos aminoácidos tem grande variação entre as diferentes 
espécies e ingredientes, não sendo adequada a utilização do valor de proteína digestível para estimar os valores de aminoácidos digestíveis, pois existem diferenças entre a digestibilidade dos aminoácidos.

De Silva et al. (2000), citam que um ingrediente protéico de alta digestibilidade não necessariamente apresenta uma alta disponibilidade de aminoácidos. Embora exista certa relação entre os valores da digestibilidade aparente da proteína e dos aminoácidos, a obtenção do coeficiente de digestibilidade individual dos aminoácidos é importante, pois ele é variável para alguns aminoácidos essenciais (Hossain \& Jauncey, 1989).

A eficiência de utilização de um nutriente pode variar em função do ingrediente ou fonte utilizada, do nível de inclusão do nutriente, do processo empregado para a confecção da dieta, da interação entre os nutrientes (Portz, 2001a) e da eficiência de utilização entre as espécies, devido às distintas características morfológicas e fisiológicas (Andrigueto et al, 1982).

Os coeficientes de digestibilidade dos nutrientes de um ingrediente ou de uma dieta são obtidos com base em medidas feitas através da coleta das fezes dos peixes, sendo seu resultado dependente das condições e metodologias utilizadas (Portz, 2001a).

A maioria dos estudos de digestibilidade com peixes é conduzida pelo método indireto, onde um marcador, que pode estar naturalmente na dieta (interno) ou introduzido em pequenas porções no alimento (externo), é utilizado para determinação da digestibilidade aparente (Storebakken et al.,1998; De Silva \& Anderson, 1995). Entre os marcadores externos, o mais utilizado e aceito nos estudos de digestibilidade é o óxido de cromo III $\left(\mathrm{Cr}_{2} \mathrm{O}_{3}\right)$ (Austreng, 1978; Vandenberg \& De La Noüe, 2001).

O marcador ideal deve ser indigestível e não absorvível, não interferir na fisiologia da digestão do animal, ter a mesma velocidade de passagem pelo sistema digestório que o resto do alimento e não deve ser tóxico (De Silva \& Anderson, 1995).

Há diversos métodos de coleta de fezes. Estas podem ser coletadas em câmaras metabólicas (Smith et al. 1980), por pipetagem direta ou peneiras acopladas no fundo dos tanques (Alliot et al., 1978; Windell et al.,1978; Spyridakis et al., 1989), por filtragem contínua (Choubert et al., 1982), por dissecação (Austreng, 1978; Hajen et al., 
1993b), por sucção anal (Windell et al., 1978; Hajen et al., 1993a) e por compressão (Hajen et al., 1993a).

Todos os métodos utilizados para determinar a digestibilidade em peixes estão sujeitos a erros (De Silva \& Anderson, 1995) devido a perdas por lixiviação e solubilidade dos componentes (Bureau et al., 1999, Hajen et al., 1993b). Portanto, o que deve ser feito durante um estudo de digestibilidade, independente do método empregado é, minimizar as possíveis perdas de nutrientes que irão ocorrer durante o experimento (Allan et al., 2000; Storebakken et al., 1998; Spyridakis et al., 1989, De Silva et al.,2000; Portz, 2001a). 


\section{CARACTERIZAÇÃO FÍSICO-QUÍMICA E NUTRICIONAL DE SILAGENS DE TILÁPIA DO NILO (Oreochromis niloticus) = PHYSICAL-CHEMICAL AND NUTRITIONAL CHARACTERIZATION OF SILAGES OF NILE TILÁPIA (Oreochromis niloticus)}

\subsection{Resumo}

Este estudo teve por objetivo a elaboração e a caracterização físico-química e nutricional da silagem ácida (SA), silagem biológica (SB) e silagem enzimática (SE), produzidas a partir de descartes da piscicultura e resíduos do beneficiamento da tilápia do Nilo (Oreochromis niloticus). Com exceção do teor de lipídios, que não apresentou diferença entre os tratamentos, todos os demais parâmetros analisados apresentaram diferenças significativas $(\mathrm{P}<0,01)$. SA, SB e SE apresentaram, respectivamente: 25,21; 34,58 e $25,01 \mathrm{~g} / 100 \mathrm{~g}$ de matéria seca, 54,$25 ; 33,00$ e $54,50 \mathrm{~g} / 100 \mathrm{~g}$ de proteína bruta, 12,$45 ; 12,25$ e 12,17 g/100g de lipídios, 26,62; 25,07 e 27,17 g/100g de cinza, 8,03; 7,33 e $8,58 \mathrm{~g} / 100 \mathrm{~g}$ de cálcio e 4,71; 2,86 e 4,85 g/100g de fósforo. As maiores concentrações entre os aminoácidos totais foram encontradas para o ácido aspártico e o ácido glutâmico. De maneira geral, entre os aminoácidos essenciais (AAE), a leucina e a lisina apresentaram-se em maior concentração. Com base no escore químico, todas as silagens

apresentaram-se deficientes em triptofano quando comparadas ao padrão de AAE da FAO/WHO (1985) e às exigências em AAE para a tilápia do Nilo de acordo com o NRC (1993). Contudo, considerando-se como aminoácidos limitantes apenas os que estiverem $30 \%$ abaixo das exigências mínimas dos peixes em geral, esses produtos não são deficientes em nenhum AAE. Conclui-se, com base nos resultados obtidos, que todas as 
silagens testadas são potencialmente viáveis para a utilização em dietas balanceadas para peixes.

\subsection{Summary}

The objective of this study was the elaboration and the physical-chemical and nutritional characterization of the acid silage (AS), biological silage (BS) and enzymatic silage (ES) produced from discardings of the culture and processing residues of the Nile tilapia (Oreochromis niloticus). Except for the lipid content, which did not differ among the treatments, all the other analyzed parameters presented significant differences $(\mathrm{P}<0.01)$. The values found (dry matter basis) were: $25.21 ; 34.58$ and $25.01 \mathrm{~g}^{1} 100 \mathrm{~g}^{-1}$ for dry matter, $54.25 ; 33.00$ and 54.50 g. $100 \mathrm{~g}^{-1}$ for protein, $12.45 ; 12.25$ and 12.17 g. $100 \mathrm{~g}^{-1}$

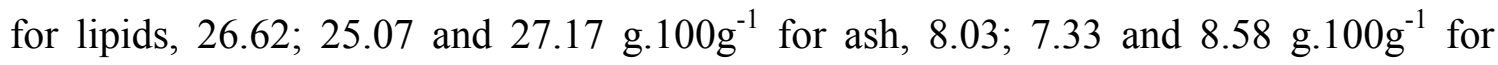
calcium and $4.71 ; 2.86$ and 4.85 g. $100 \mathrm{~g}^{-1}$ for phosphorus for AS, BS and ES, respectively. The highest concentrations among total amino acids were found for aspartic acid and glutamic acid. In general, among essential amino acids (EAA), leucine and lysine had the highest concentrations. Based on the chemical score, all the silages were triptophane-deficient when compared to the EAA standards of FAO/WHO (1985) and to the EAA requirements for the Nile tilapia, according to the NRC (1993). However, considering that limiting amino acids are only the ones $30 \%$ below the minimum requirements for fish in general, these products are not deficient in any EAA. We conclude, according to the results of this research, that all the tested silages are potentially viable for the use in balanced fish diets.

\subsection{Introdução}

As perdas pós-captura do pescado superam a $10 \%$ do total. Somando-se a isso as perdas que ocorrem durante o manejo, armazenamento, processamento e comercialização, estas podem superar $60 \%$ do total produzido (Parín \& Zugarramurdi, 1994; Raa \& Gilberg, 1982). 
O aproveitamento desse material, rico em proteína e lipídios, que seria desperdiçado é de extrema importância, pois além de diminuir os custos e aumentar a eficiência de produção, também minimiza os problemas de poluição ambiental que seriam gerados pela falta de destino adequado para este material (Dapkevicius et al., 1998, 2000; Honczaryk \& Maeda, 1998; Morales-Ulloa, 1994; Samuels et al., 1991; Valério, 1994).

Pesquisas têm sido conduzidas com esse objetivo e uma alternativa viável que se apresenta é a transformação desse resíduo em silagem de pescado. Esta é uma técnica simples, prática, o equipamento essencial é de baixo custo e a escala de produção é variável, sendo muito conveniente ecológica e financeiramente (Disney et al., 1977; Jackson et al., 1984a, 1984b; Ottati, 1990; Tatterson \& Windsor, 1974).

O produto final é estável com alto valor nutricional e biológico para a alimentação animal, conservando a qualidade protéica do produto, particularmente de aminoácidos como a lisina, metionina e cistina (Coello et al., 2000; Ristic et al., 2002; Vidotti et al., 2003).

A ensilagem de resíduos de pescado é uma técnica antiga de preservação da matéria orgânica (Hammoumi et al., 1998; Shirai et al., 2001), a qual pode ser elaborada quimicamente, através da acidificação direta utilizando ácidos orgânicos e/ou minerais (Espíndola Filho, 1997, 1999; Haard et al., 1985; Kompiang, 1981; Rivero \& Viana, 1996), biologicamente, quando a acidificação é realizada por microrganismos produtores de ácido lático (Hassan \& Heath, 1987; Vizcarra-Magaña et al., 1999; Zahar et al., 2002) ou pela combinação dos dois métodos (Morales-Ulloa, 1994; Morales-Ulloa \& Oetterer, 1995). Durante o processo de ensilagem, as proteínas são hidrolisadas pela ação das enzimas naturalmente presentes no pescado e/ou adicionadas (silagem enzimática), favorecidas pelo ajuste da acidez que também ajuda a inibir a ação microbiana, originando um produto liquefeito, rico em proteínas, peptídeos de cadeia curta e aminoácidos livres (Stone \& Hardy, 1986).

A composição da silagem é muito semelhante à matéria-prima que the deu origem, porém o valor nutricional da silagem pode ser afetado, negativamente, com o 
aumento do tempo de estocagem, devido a formação de grande quantidade de aminoácidos livres (Espe \& Lied, 1999; Kompiang, 1981; Viana et al., 1999).

Acredita-se que o grau de hidrólise pode ser usado como critério químico para avaliar a qualidade da silagem de pescado (Espe et al., 1989; Espe \& Lied, 1999). Segundo Stone et al. (1989), o valor nutricional da silagem pode ser significantemente aumentado, limitando a hidrólise das proteínas e polipeptídeos em aminoácidos livres. Os mesmos autores citam que, assim como em humanos, os peptídeos de cadeia curta (di e tripeptídeos) são melhor absorvidos, pelos peixes, que os aminoácidos livres.

$\mathrm{O}$ produto final do processo de ensilagem pode ser considerado como importante fonte alternativa de proteína na alimentação animal, principalmente em situações em que a produção da farinha de peixe não é viável e/ou o custo dessa fonte protéica é muito alto (Disney et al., 1977; Hussain \& Offer, 1987).

A utilização de resíduos de pescado para a produção da silagem pode contribuir para a redução da poluição ambiental, gerada pelo acúmulo desse material orgânico e para a redução do custo das rações (Guzmán \& Viana, 1998).

Segundo Espíndola Filho (1997), é de grande relevância o aproveitamento de resíduos na cadeia produtiva de pescado, com intuito de evitar desperdícios, reduzir os custos de produção do pescado e a poluição ambiental, pois com a criação de alternativas tecnológicas com valor agregado e com a utilização prática do gerenciamento dos resíduos, teremos como resultado a geração de empregos e o caminho para o desenvolvimento sustentável.

Este trabalho teve por objetivo a elaboração e a caracterização físico-química e nutricional das silagens ácida, biológica e enzimática de tilápia do Nilo (Oreochromis niloticus).

\subsection{Material e métodos}

\subsubsection{Matéria-prima}

A matéria-prima utilizada para a elaboração das silagens era formada de aproximadamente $20 \%$ de resíduos de tilápias do Nilo (Oreochromis niloticus) do 
processamento (filetagem) conduzido no Departamento de Agroindústria, Alimentos e Nutrição da ESALQ-USP, constituído de cabeças, vísceras, escamas, nadadeiras, coluna vertebral, pele e tecidos aderidos e de aproximadamente $80 \%$ de tilápias do Nilo inteiras (descarte), provenientes do Setor de Piscicultura do Departamento de Zootecnia da ESALQ-USP. Este material foi moído em equipamento elétrico, modelo ML-4.0/Weg$\mu$ line, transformando-se numa massa homogênea, totalizando $60 \mathrm{~kg}$.

\subsubsection{Silagem ácida}

A massa homogênea obtida como em 2.1, foi dividida igualmente em seis recipientes de plástico. Cada recipiente recebeu $10 \mathrm{~kg}$ da massa homogênea, $200 \mathrm{mg} / \mathrm{kg}$ de BHT (Butil Hidroxi Tolueno), dissolvido em álcool etílico e 3\% (volume/peso) de uma mistura de ácido fórmico a $88 \%$ e ácido propiônico a 100\%, na proporção de 1:1.

A massa foi revolvida manualmente, com o auxílio de uma espátula, visando acidificação homogênea; posteriormente, os recipientes foram fechados com tampas plásticas e mantidos ao ambiente.

Decorridos três dias foi removida a camada lipídica sobrenadante.

A silagem ácida constituiu-se em um pré-tratamento para a produção das demais silagens. Dos 6 recipientes, 2 foram mantidos como silagem ácida por 4 semanas e os demais foram destinados aos tratamentos biológico e enzimático (Figura 1).

\subsubsection{Silagem biológica}

A silagem biológica foi preparada a partir da silagem ácida, decorridos 3 dias do tempo inicial, quando foi removida a camada lipídica sobrenadante.

Foram utlizados 2 recipientes com $10 \mathrm{~kg}$ de silagem ácida cada (prétratamento) e em cada um, foram adicionados $0,014 \%(\mathrm{p} / \mathrm{p})$ de solução inóculo de Lactobacillus plantarum (descrito no item 2.4.) e 18\% (p/p) de melaço de cana, proveniente da Usina Santa Elisa, SP, na forma de pó com 4\% de umidade e diluído em água destilada até atingir aproximadamente $24 \%$ de umidade. A massa foi revolvida manualmente com espátula, os recipientes foram fechados com tampas plásticas e mantidos ao ambiente por 3 semanas. 


\subsubsection{Obtenção da solução inóculo}

Foi utilizada como inóculo o Lactobacillus plantarum, produtor de ácido lático.

Procedeu-se a multiplicação das células partindo-se de uma alíquota de $0,1 \mathrm{~mL}$ da cultura previamente ativada, inoculada em tubo de ensaio contendo $5 \mathrm{~mL}$ de meio de cultivo Mann Rugosa Sharp (MRS) Broth Lactobacili produzida pela DIFCO, sendo então incubado a $35^{\circ} \mathrm{C}$ por $24 \mathrm{~h}$.

Após 24 horas, alíquotas de $5 \mathrm{~mL}$ dos tubos de ensaio foram inoculadas em erlenmeyers contendo $500 \mathrm{~mL}$ do meio MRS, seguindo-se incubação a $35^{\circ} \mathrm{C}$ por $48 \mathrm{~h}$, para assim obter concentrações de pelo menos $10^{8}$ células $/ \mathrm{mL}$ (meio inóculo).

O material contendo os microrganismos foi centrifugado em uma centrífuga modelo BHG - Hermle/Z320 (4000xG), a $25^{\circ} \mathrm{C}$, por $15 \mathrm{~min}$, para a separação da massa de células. As massas centrifugadas foram suspensas em solução salina a $0,85 \%$ até completar $40 \mathrm{~mL}$ (solução inóculo).

\subsubsection{Silagem enzimática}

A silagem enzimática foi preparada a partir da silagem ácida, decorridos 3 dias do tempo inicial, quando foi removida a camada lipídica sobrenadante

Foram utlizados 2 recipientes com $10 \mathrm{~kg}$ de silagem ácida (pré-tratamento). A cada um dos recipientes foram adicionados $10 \mathrm{~g}$ da enzima protease, tipo II de Aspergillus oryzae, com 0,13 unidades/mg de sólidos, produzida pela Sigma Chemical Corporation, diluída em $100 \mathrm{~mL}$ de água destilada, segundo Valério (1994). A massa foi revolvida manualmente com espátula, os recipientes foram fechados com tampas plásticas e mantidos ao ambiente por uma semana.

\subsubsection{Determinação do $\mathrm{pH}$}

Para a determinação do pH utilizou-se o potênciometro digital, marca Digimed, expressando resultados em duas casas decimais. 


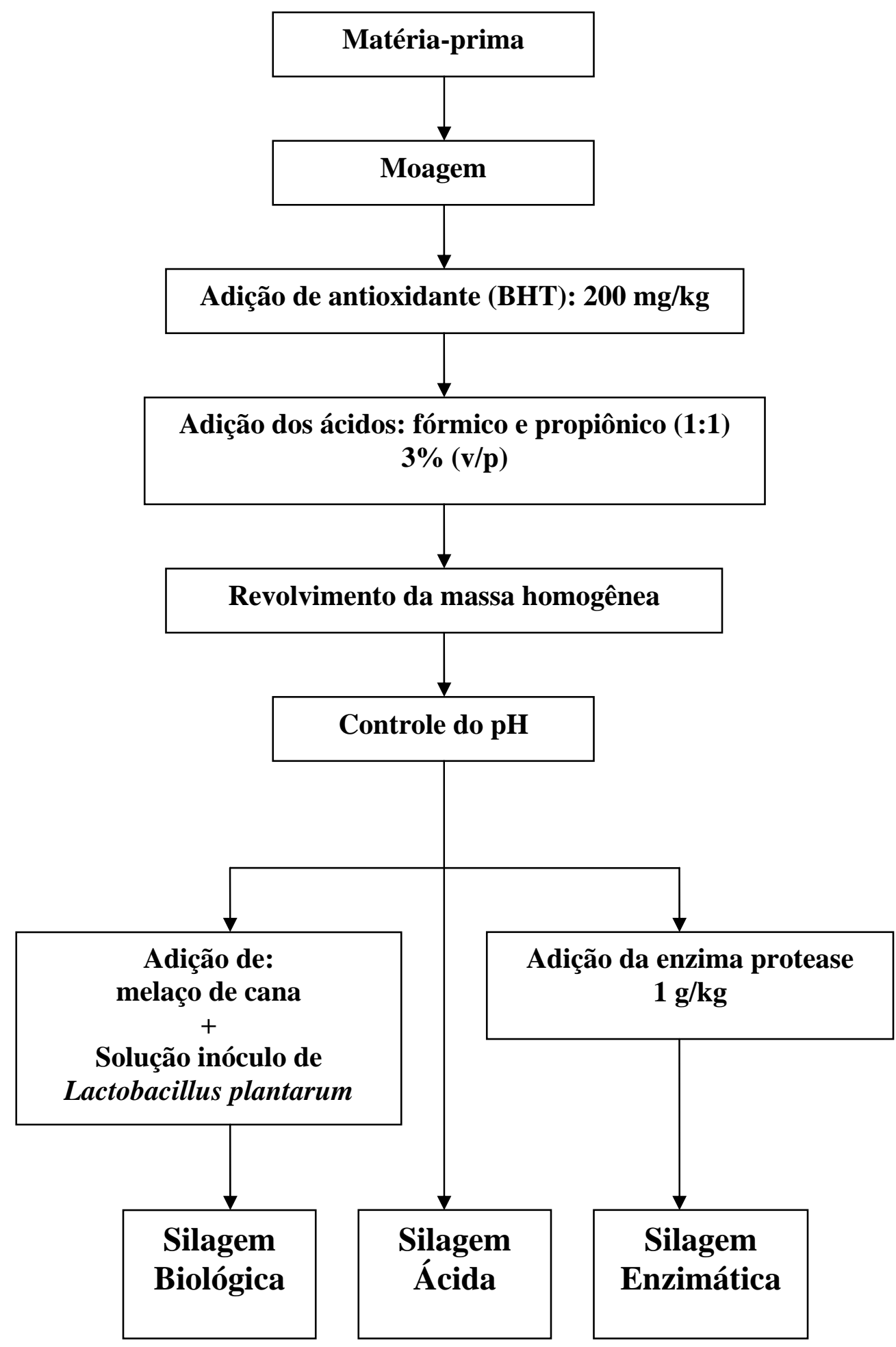

Figura 1 - Fluxograma de obtenção das silagens ácida, biológica e enzimática. 


\subsubsection{Análises químicas}

As análises químico-bromatológicas das silagens e da matéria-prima foram realizadas com base na matéria seca de acordo com os procedimentos da AOAC (1984), sob a padronização do Compêndio Brasileiro de Nutrição Animal (BRASIL, 1998). A umidade foi determinada através do método gravimétrico, em estufa a $105^{\circ} \mathrm{C}$ até peso constante. $\mathrm{O}$ teor de cinza foi determinado pelo método gravimétrico, em mufla a $550^{\circ} \mathrm{C}$ e incineração da matéria orgânica em bico de Bunsen. $O$ teor de proteína bruta foi determinado pelo método de micro-Kjedahl e o extrato etéreo foi determinado após extração com éter de petróleo pelo método de Soxhlet. Os minerais, cálcio e fósforo, foram quantificados por espectrofotometria de absorção atômica, após digestão ácida, pelo laboratório CBO Assessoria e Análises, localizado em Campinas, São Paulo.

\subsubsection{Análise dos aminoácidos}

As amostras foram analisadas por cromatografia líquida, em colunas de resinas de troca catiônica e derivação pós-coluna com ninhidrina, em auto analisador. Para a quantificação dos aminoácidos, as amostras foram hidrolisadas com $\mathrm{HCl} 6 \mathrm{~N}$, por 22 horas a $110^{\circ} \mathrm{C}$, de acordo com o método descrito por Moore \& Stein (1963).

$\mathrm{O}$ triptofano foi determinado após hidrólise enzimática com pronase a $40^{\circ} \mathrm{C}$ por 24 horas, seguido de reação colorimétrica com 4-Dimetil-Amino-Benzaldeído (DAB) em ácido sulfúrico $21,2 \mathrm{~N}$ e leitura a $590 \mathrm{~nm}$. O teor de triptofano foi calculado a partir de uma curva padrão, segundo Spies (1967).

As análises foram realizadas pelo laboratório CBO Assessoria \& Análise, localizado em Campinas, São Paulo.

\subsubsection{Determinação do escore químico de aminoácidos essenciais}

A determinação do escore químico foi feita segundo Sgarbieri (1987), através da relação entre o teor de cada aminoácido essencial $(\mathrm{g} / 100 \mathrm{~g}$ de proteína bruta) com o teor do aminoácido correspondente de uma proteína padrão ( $\mathrm{g} / 100 \mathrm{~g}$ de proteína bruta). Nesta pesquisa, o escore das silagens ácida, biológica e enzimática de tilápia foi calculado utilizando como padrão as exigências em aminoácidos essenciais para a tilápia 
do Nilo (Oreochromis niloticus) estabelecidos pelo National Research Council - NRC (1993).

\subsubsection{Análise do perfil de ácidos graxos}

Os ácidos graxos foram analisados por cromatografia gasosa de alta resolução (HRGC) após esterificação em metanol/ácido sulfúrico, segundo Hartman \& Lago (1973).

As análises foram realizadas pelo laboratório CBO Assessoria \& Análise, localizado em Campinas, São Paulo.

\subsubsection{Análises estatísticas}

Os dados obtidos foram submetidos à análise de variância (ANOVA) e depois submetidos ao teste de comparação de médias Tukey $(\mathrm{P}<0,05)$, pelo aplicativo SAS (1985).

\subsection{Resultados e discussão}

De acordo com Morales-Ulloa (1994) e Valério (1994) a adição de ácidos é uma etapa importante para a conservação da massa homogênea de pescado, constituindo-se em uma primeira etapa indispensável para a elaboração das silagens biológica e enzimática. Assim, no presente estudo utilizou-se a silagem ácida como prétratamento à elaboração das demais silagens.

Pelo exame visual das silagens, observou-se que a liquefação da massa homogênea iniciou-se entre o $2^{\circ}$ e $3^{\circ}$ dias e aumentou, gradativamente, até o final do experimento resultando num produto com característica líquido-pastosa, corroborando o observado por Hardy et al. (1983). Este aspecto é resultado da contínua hidrólise protéica que acontece na silagem devido à ação das enzimas proteolíticas naturalmente presentes no pescado, principalmente nas vísceras e/ou adicionadas (Haard et al., 1985; Kompiang, 1981). 
Quanto à coloração, as silagens ácida e enzimática apresentaram cor marrom claro, já a silagem biológica, apresentou coloração marrom escura, confirmando o relatado por Valério (1994) e Morales-Ulloa \& Oetterer (1995). Essa coloração pode ser resultado da reação de Maillard, em decorrência da presença do melaço como fonte de carboidrato e dos aminoácidos livres, propiciando a ocorrência dessa reação (Fagbenro 1994; Fagbenro \& Jauncey, 1998).

$\mathrm{O}$ aroma levemente ácido apresentado pela silagem ácida (SA) e silagem enzimática (SE) está associado ao emprego de ácidos orgânicos como o ácido fórmico e o ácido propiônico que propiciam a obtenção de silagens com odor ácido menos pronunciado, além de serem menos corrosivos e, portanto de mais fácil manipulação.

A silagem biológica (SB) apresentou aroma "doce-acidificado" devido à adição do melaço, que descaracteriza de certa forma o aroma ácido encontrado nas silagens ácida e enzimática estando de acordo com o relatado por Morales-Ulloa (1994).

Em função destes odores ácidos exalados pelas silagens, o produto não atraiu insetos, confirmando o que foi relatado por Nunes (1999) e Raa \& Gilberg (1982).

$\mathrm{O}$ pH das silagens está apresentado na Tabela 1. As silagens ácida, biológica e enzimática apresentaram valores finais de $\mathrm{pH}$ de 4,24, 4,30 e 4,26, respectivamente.

Tabela 1. Valores de pH da matéria-prima e das silagens ácida, biológica e enzimática.

\begin{tabular}{lcccccccc}
\hline & \multicolumn{8}{c}{ Dias } \\
\cline { 2 - 9 } & 0 & 1 & 3 & 5 & 10 & 14 & 21 & 28 \\
\hline Matéria-prima & 6,70 & - & - & - & - & - & - & - \\
Silagem ácida & - & 3,80 & 4,00 & 4,35 & 4,33 & 4,30 & 4,28 & 4,24 \\
Silagem biológica & - & - & 4,08 & 4,34 & 4,31 & 4,29 & 4,30 & - \\
Silagem enzimática & - & - & 3,99 & 4,30 & 4,26 & - & - & - \\
\hline
\end{tabular}

$\mathrm{O}$ pH ácido (abaixo de 4,5) aliado à ação bactericida do ácido propiônico garantiu a qualidade das silagens ácida e enzimática durante todo o período experimental, fato verificado por Valério (1994). 
A idéia é de que a preservação não dependa somente da acidez, mas também da escolha de um ácido que tenha ação bactericida, caso do ácido propiônico (Raa \& Gilberg, 1982).

$\mathrm{Na} \mathrm{SB}$, além destes dois fatores, há também a provável ação de substâncias antibióticas, denominadas bacteriocinas, produzidas pelas bactérias ácido-láticas que inibem o crescimento de microrganismos putrefativos e patogênicos que auxiliam na conservação do produto final (Morales-Ulloa, 1994; Raa \& Gilberg, 1982).

$\mathrm{Na}$ Tabela 2 estão apresentados os valores da composição químicobromatológica da matéria-prima e das silagens. Analisando apenas as silagens, com exceção do teor de lipídios, todos os demais parâmetros apresentaram diferença significativa $(\mathrm{P}<0,01)$.

A silagem enzimática apresentou valores maiores para os teores de cinza (C), nitrogênio não protéico $(\mathrm{NNP})$, cálcio $(\mathrm{Ca})$ e fósforo $(\mathrm{P})$. Por outro lado, a silagem ácida obteve maiores valores para a energia bruta $(\mathrm{EB})$.

Os maiores valores de proteína bruta $(\mathrm{PB})$ foram obtidos pelas silagens ácida $(54,25 \mathrm{~g} / 100 \mathrm{~g})$ e enzimática $(54,50 \mathrm{~g} / 100 \mathrm{~g})$. A menor quantidade de PB na silagem biológica $(33,00 \mathrm{~g} / 100 \mathrm{~g})$ ocorreu devido a adição do melaço, que levou a uma diluição do sistema, pela incorporação de umidade e sólidos (Morales-Ulloa \& Oetterer, 1995).

Como pode ser observado na Tabela 2, houve declínio da fração protéica, acompanhada de um aumento do teor de nitrogênio não protéico, nas silagens, quando comparadas à matéria-prima. Este declínio progressivo do teor de $\mathrm{PB}$ e aumento do teor de NNP é conseqüência da contínua hidrólise protéica decorrente da ação das enzimas proteolíticas, favorecidas pelo abaixamento do pH (Stone \& Hardy, 1986; Tatterson \& Windsor, 1974).

A composição da silagem se apresenta muito próxima à matéria-prima, portanto os teores de proteína bruta podem variar consideravelmente dependendo do material utilizado na sua elaboração. A metodologia também pode interferir na composição devido a diluição provocada pelos ácidos, soluções inoculo e melaço.

Hossain et al. (1997) elaboraram silagens ácidas com diferentes matériasprimas (peixes inteiros descartados) utilizando o ácido sulfúrico e o ácido fórmico. Estes 
autores obtiveram teores de proteína bruta de $56,50 \mathrm{~g} / 100 \mathrm{~g}$ para a silagem ácida produzida com 3,5\% (v/p) de ácido sulfúrico e de $56,45 \mathrm{~g} / 100 \mathrm{~g}$ para a silagem produzida com 3\% (v/p) de ácido fórmico. Tais valores são próximos aos encontrados nesta pesquisa, para as silagens ácida e enzimática.

Para a silagem biológica, os resultados de PB se aproximaram aos obtidos por Vidotti et al. (2003), da ordem de 35,84 g/100g, que trabalharam em silagem biológica de tilápia do Nilo e Johnson et al. (1985), d ordem de 32,30 g/100g, em silagem biológica produzida a partir de diferentes matérias-primas.

Oliveira (2003), trabalhando com a silagem ácida, elaborada com sardinhas (Sardinella brasiliensis) inteiras, utilizando 3,5\% (v/p) de uma mistura (3:1) de ácido sulfúrico:fórmico, obteve teor de PB de 58,71 g/100g. Valério (1994) elaborou silagem enzimática de sardinha (Sardinella brasiliensis), utilizando a enzima protease, e obteve valor de $\mathrm{PB}$ de $65,07 \mathrm{~g} / 100 \mathrm{~g}$. Estes teores foram superiores aos encontrados nesta pesquisa.

A diminuição do teor de lipídios das silagens com relação à matéria-prima foi devido à retirada da porção lipídica sobrenadante, após três dias de desenvolvimento das silagens.

Alguns autores citam que esta fração interfere na qualidade da silagem, pois como os ácidos graxos que constituem a fração lipídica do pescado são, predominantemente, insaturados, estes podem oxidar facilmente resultando em alterações de sabor, cor, textura, valor nutricional, além de serem considerados potenciais produtores de componentes tóxicos (FAO, 2003; Raa \& Gilberg, 1982; Sales, 1995). O processo oxidativo pode ser acelerado se a silagem de pescado estiver em contato com a luz e o ar (FAO, 2003).

De acordo com Nelson \& Cox (2001) a oxidação de lipídios pode causar a formação de peróxidos que podem complexar as proteínas através de ligações físicas e covalentes. Essas ligações covalentes entre produtos oxidados e proteínas podem destruir aminoácidos como o triptofano, oxidar metionina e ligar a lisina a outros compostos tornando estes aminoácidos indisponíveis (Sales, 1995). 
Tabela 2. Composição químico-bromatológica, energia e nutrientes da matéria-prima e das silagens biológica, ácida e enzimática, em g/100g na matéria seca.

\begin{tabular}{lcccccc}
\hline & $\begin{array}{c}\text { Matéria- } \\
\text { prima }\end{array}$ & $\begin{array}{c}\text { Silagem } \\
\text { biológica }\end{array}$ & $\begin{array}{c}\text { Silagem } \\
\text { ácida }\end{array}$ & $\begin{array}{c}\text { Silagem } \\
\text { enzimática }\end{array}$ & $\begin{array}{c}\text { Erro } \\
\text { padrão }\end{array}$ & $\begin{array}{c}\text { ANOVA } \\
\text { Pr }>\text { F }\end{array}$ \\
\hline Matéria seca & $36,89^{\mathrm{a}} \pm 0,10$ & $34,58^{\mathrm{b}} \pm 0,20$ & $25,21^{\mathrm{c}} \pm 0,17$ & $25,01^{\mathrm{c}} \pm 0,11$ & 0,0413 & 0,0001 \\
Proteína & $59,64^{\mathrm{a}} \pm 0,29$ & $33,00^{\mathrm{c}} \pm 0,26$ & $54,25^{\mathrm{b}} \pm 0,50$ & $54,50^{\mathrm{b}} \pm 0,30$ & 0,0754 & 0,0001 \\
Lipídeo & $18,41^{\mathrm{a}} \pm 0,41$ & $12,25^{\mathrm{b}} \pm 0,45$ & $12,45^{\mathrm{b}} \pm 0,45$ & $12,17^{\mathrm{b}} \pm 0,18$ & 0,1214 & 0,0001 \\
Cinza & $17,73^{\mathrm{c}} \pm 0,04$ & $25,07^{\mathrm{b}} \pm 0,49$ & $26,62^{\mathrm{a}} \pm 0,34$ & $27,17^{\mathrm{a}} \pm 0,28$ & 0,0682 & 0,0001 \\
NNP* & $0,52^{\mathrm{c}} \pm 0,16$ & $3,29^{\mathrm{b}} \pm 0,30$ & $5,87^{\mathrm{a}} \pm 0,17$ & $6,57^{\mathrm{a}} \pm 0,27$ & 0,0770 & 0,0001 \\
Energia** & - & $4334,50^{\mathrm{b}} \pm 34,30$ & $4678,00^{\mathrm{a}} \pm 28,00$ & $3809,85^{\mathrm{c}} \pm 29,85$ & 2305,0860 & 0,0002 \\
Cálcio & - & $7,33^{\mathrm{c}} \pm 0,04$ & $8,03^{\mathrm{b}} \pm 0,08$ & $8,58^{\mathrm{a}} \pm 0,05$ & 0,0044 & 0,0002 \\
Fósforo & - & $2,86^{\mathrm{b}} \pm 0,06$ & $4,71^{\mathrm{a}} \pm 0,03$ & $4,85^{\mathrm{a}} \pm 0,05$ & 0,0044 & 0,0001 \\
\hline
\end{tabular}

Nota: os valores se constituem em média de três repetições \pm erro padrão; letras iguais não diferem significativamente a $\mathrm{P}<0,01$.

*NNP $=$ Nitrogênio não protéico

**Energia bruta expressa em cal/g 
Portanto, devido a todos estes fatores existem autores (Disney et al., 1977; Kompiang, 1981; Raa \& Gilberg, 1982; Tatterson \& Windsor, 1974) que defendem a retirada da fração lipídica, durante a elaboração da silagem, para a obtenção de um produto uniforme e de maior estabilidade.

Os teores elevados de lipídios encontrados nas silagens produzidas nesta pesquisa, se devem à presença de vísceras e gordura cavitária na matéria-prima utilizada na elaboração das mesmas.

Os resultados obtidos para a fração lipídica por Fagbenro (1996) e Fagbenro \& Jauncey (1995a), trabalhando com a silagem biológica foram 10,86 e 10,63 g/100g, respectivamente. Ristic et al. (2002), Disney et al. (1977) e Sales (1995) analisando a silagem ácida encontraram os valores de 14,85; 12,20 e 14,29 g/100g, respectivamente. Dapkevicius et al. (1998) trabalhando com as silagens ácida e biológica verificaram valores de lipídios de 14,90 e 10,30 g/100g, respectivamente. Todos estes resultados estão próximos aos obtidos nesta pesquisa.

A composição final da silagem varia, consideravelmente, com o tipo de matéria-prima empregada, particularmente quanto ao teor de lipídios, que é variável com a estação da captura, espécie, tipo de resíduo utilizado (vísceras) e sexo (Brown \& Sumner, 1985; Disney et al., 1977; Haard et al., 1985).

Segundo Raa \& Gilberg (1982) para evitar problemas com “off flavor", quando a silagem for oferecida para suínos ou aves, o óleo proveniente do pescado não deve superar a $1 \%$ do total da ração.

Os teores elevados de cinza, observados nas silagens ácida, biológica e enzimática, estão diretamente relacionados com a presença de grande quantidade de escamas, cabeça, coluna vertebral, ossos e nadadeiras na matéria-prima utilizada para a elaboração das silagens.

Os teores de cinza das silagens analisadas nesta pesquisa estão próximos aos encontrados por Neethiselvan et al. (2001), Berenz (1994) e Hammoumi et al. (1998), a saber, 23,59, 22,21 e 21,90 g/100g, respectivamente, em silagens biológicas.

Em relação aos valores de cálcio e fósforo obtidos nesta pesquisa, podemos associar a riqueza destes elementos nas silagens à porção óssea e às escamas, que 
contêm teores relativamente elevados destes elementos na forma de fosfato tricálcico e carbonato de cálcio (Sales, 1995).

Os teores de $\mathrm{Ca}$ e $\mathrm{P}$ obtidos nesta pesquisa, ficaram acima dos apresentados por Espíndola Filho (1999), para a silagem ácida, cujos valores foram, 4,11 e 1,80\% para o Ca e P, respectivamente. Foram superiores também aos apresentados por Berenz (1994), que encontrou valores de 1,54\% para o $\mathrm{Ca}$ e 1,06\% para o $\mathrm{P}$; ficaram, no entanto, próximos aos obtidos por Sales (1995), que trabalhou com a silagem ácida de resíduo de tilápia do Nilo, utilizando ácido fórmico a $3 \%(\mathrm{v} / \mathrm{p})$. Este autor encontrou valores de $6,32 \%$ para o $\mathrm{Ca}$ e $4,33 \%$ para o $\mathrm{P}$.

Stone \& Hardy (1986) avaliaram os teores de cálcio e fósforo de algumas espécies de peixes e concluíram que estes são extremamente variáveis entre as espécies e porção analisada (carne, vísceras). Essas flutuações estão também associadas a fatores como idade, sexo e teor de cálcio na água.

De uma maneira geral, podemos observar que a composição centesimal é extremamente variável de uma espécie de pescado para outra e em uma mesma espécie dependendo da época do ano, do tipo de alimentação, do grau de maturação gonadal, sexo e, em um mesmo peixe, vai variar dependendo da parte analisada (Sales,1995). Como a composição da silagem é muito semelhante à matéria-prima, o valor nutricional da silagem também vai variar segundo os fatores supra citados.

Conforme pode ser observado na Tabela 3, os ácidos graxos presentes na fração lipídica das silagens são, predominantemente, os insaturados, sendo que o oléico apresentou-se em maior quantidade. Já entre os ácidos graxos saturados, o palmítico e o esteárico, ocorreram em maior quantidade. Estes resultados corroboram os apresentados por Maia et al. (1998), Sales (1995) e Valério (1994).

A composição em ácidos graxos da silagem de pescado é bastante variável, dependendo diretamente da matéria-prima utilizada na sua elaboração. Espíndola Filho (1999) avaliando a silagem ácida, produzida a partir de diferentes espécies de pescado, encontrou maior quantidade de ácidos graxos saturados que insaturados, fato associado à presença do camarão rosa (Farfantopenaeus brasiliensis) e do camarão sete barbas 
(Xiphopenaeus kroyeri) como componentes da matéria-prima utilizada para a elaboração da silagem ácida.

Tabela 3. Ácidos graxos das silagens ácida, biológica e enzimática (g/100g de lipídios).

\begin{tabular}{|c|c|c|c|c|}
\hline \multicolumn{2}{|l|}{ Ácidos Graxos } & $\begin{array}{l}\text { Silagem } \\
\text { Biológica }\end{array}$ & $\begin{array}{l}\text { Silagem } \\
\text { Ácida }\end{array}$ & $\begin{array}{c}\text { Silagem } \\
\text { Enzimática }\end{array}$ \\
\hline Dodecanóico & $\mathrm{C} 12$ & $<0,01$ & 0,11 & 0,23 \\
\hline Mirístico & $\mathrm{C} 14$ & 3,80 & 4,74 & 5,36 \\
\hline Pentadecanóico & $\mathrm{C} 15$ & 0,70 & 0,81 & 0,60 \\
\hline Palmítico & $\mathrm{C} 16$ & 28,50 & 33,19 & 35,19 \\
\hline Palmitoleico & C16:1 & 8,60 & 9,94 & 10,70 \\
\hline Margárico & $\mathrm{C} 17$ & 0,90 & 0,56 & 1,00 \\
\hline Esteárico & $\mathrm{C} 18$ & 6,08 & 5,60 & 5,70 \\
\hline Oléico & C18:1 & 30,49 & 28,60 & 30,60 \\
\hline Linoléico & C18:2 & 17,38 & 16,30 & 14,10 \\
\hline Linolênico & C18:3 & 3,10 & 3,10 & 3,20 \\
\hline Octadecatetraenóico & C18:4 & 1,52 & 1,50 & 1,20 \\
\hline Araquídico & $\mathrm{C} 20$ & 0,80 & 1,30 & 1,20 \\
\hline cis-11-Eicosenóico & C20:1 & 2,79 & 1,60 & 1,20 \\
\hline Eicosapentaenóico & $\mathrm{C} 20: 5$ & $<0,01$ & $<0,01$ & $<0,01$ \\
\hline Docosahexaenóico & $\mathrm{C} 22: 6$ & $<0,01$ & $<0,01$ & $<0,01$ \\
\hline
\end{tabular}

Nesta pesquisa foram encontrados apenas traços dos ácidos graxos eicosapentaenóico (EPA) e docosahexaenóico (DHA), diferindo dos resultados obtidos por Maia et al. (1998), que obtiveram valores de 2,3 e 9,7 g/100g de óleo, respectivamente, no óleo da silagem ácida de resíduo de tilápia. Espíndola Filho (1999) encontrou valores de $1,1 \mathrm{~g} / 100 \mathrm{~g}$ de óleo para o EPA e $1,1 \mathrm{~g} / 100 \mathrm{~g}$ de óleo para o DHA, estudando a silagem ácida, com 60 dias de armazenamento, e produzida a partir de diferentes matérias-primas. Os resultados obtidos por Maia et al. (1998) podem ser 
explicados pela grande quantidade de tecidos que fazem parte do sistema nervoso (cérebro, olhos) na matéria-prima, que segundo Tocher et al. (1997), são ricos em EPA e DHA.

Valério (1994) trabalhando com as silagens ácida e enzimática e Morales-Ulloa (1994) trabalhando com a silagem biológica, encontraram teores de EPA entre 7,01 e 7,92 g/100g de óleo e de DHA entre 17,99 e 18,21 g/100g de óleo. Estes teores elevados obtidos pelas autoras, estão relacionados com a matéria-prima utilizada para a confecção das silagens, a sardinha (Sardinella brasiliensis), peixe rico em ácidos graxos poliinsaturados.

De acordo com Sales (1995), os ácidos graxos insaturados são responsáveis por grande parte das alterações oxidativas nos alimentos, produzindo efeitos indesejáveis como a rancidez, a descoloração e a perda de nutrientes, daí a importância do uso adequado de um antioxidante.

$\mathrm{Na}$ Tabela 4 estão apresentados os teores de aminoácidos das silagens ácida, biológica e enzimática, produzidas neste experimento. Como pode ser observado, entre os aminoácidos essenciais, a leucina e a lisina se apresentam em maior concentração nas silagens elaboradas, confirmando os resultados apresentados para várias espécies de peixes por Hassan \& Heath (1987); Jackson et al. (1984a); Johnson et al. (1985); Morales-Ulloa \& Oetterer (1997); Vidotti et al. (2003).

Ainda entre os aminoácidos essenciais, o triptofano, apresentou-se em menor concentração nos três tipos de silagem, corroborando Strom \& Eggum (1981) e Espe et al. (1989). De acordo com Fagbenro \& Bello-Olusoji (1997), o triptofano é lábil em condições ácidas e nas silagens biológicas sua perda pode ser atribuída à sua interação com os açúcares não utilizados.

Raa \& Gilberg (1982) relatam que o triptofano é instável quando se apresenta na forma livre, porém é estável quando está ligado a uma proteína.

Entre os aminoácidos não essenciais o ácido glutâmico e o ácido aspártico apresentaram-se em maiores concentrações, confirmando os resultados obtidos por Espíndola Filho (1999). 
Tabela 4. Aminoácidos das silagens biológica, ácida e enzimática $(\mathrm{g} / 100 \mathrm{~g}$ de matéria seca).

\begin{tabular}{|c|c|c|c|}
\hline Aminoácidos & $\begin{array}{l}\text { Silagem } \\
\text { biológica }\end{array}$ & $\begin{array}{l}\text { Silagem } \\
\text { ácida }\end{array}$ & $\begin{array}{c}\text { Silagem } \\
\text { enzimática }\end{array}$ \\
\hline \multicolumn{4}{|l|}{ ESSENCIAIS } \\
\hline Valina & 1,42 & 2,70 & 2,98 \\
\hline Metionina & 1,86 & 2,17 & 2,21 \\
\hline Isoleucina & 1,20 & 3,23 & 2,21 \\
\hline Leucina & 2,41 & 3,50 & 3,31 \\
\hline Treonina & 1,64 & 2,04 & 2,10 \\
\hline Fenilalanina & 1,31 & 2,05 & 2,21 \\
\hline Lisina & 2,41 & 3,33 & 3,22 \\
\hline Histidina & 0,99 & 1,40 & 1,32 \\
\hline Arginina & 1,86 & 2,90 & 2,98 \\
\hline Triptofano & 0,24 & 0,36 & 0,40 \\
\hline \multicolumn{4}{|c|}{ NÃO ESSENCIAIS } \\
\hline Cistina & 0,66 & 0,77 & 0,78 \\
\hline Tirosina & 0,99 & 1,30 & 1,32 \\
\hline Ácido Aspártico & 4,05 & 5,46 & 5,51 \\
\hline Serina & 1,09 & 1,83 & 1,87 \\
\hline Ácido Glutâmico & 3,61 & 6,01 & 6,95 \\
\hline Prolina & 2,41 & 2,80 & 2,88 \\
\hline Glicina & 2,63 & 4,41 & 4,30 \\
\hline Alanina & 2,30 & 3,76 & 4,19 \\
\hline
\end{tabular}

$\mathrm{Na}$ Tabela 5, podemos comparar o perfil em AAE (g/100g de proteína bruta) das silagens produzidas nesta pesquisa com o perfil em AAE da farinha de peixe e farelo de soja determinado por Portz (2001). 
Tabela 5. Composição em aminoácidos essenciais (AAE) das silagens ácida, biológica e enzimática e da farinha de peixe e farelo de soja (resultados expressos em $\mathrm{g} / 100 \mathrm{~g}$ de proteína bruta).

\begin{tabular}{lccccc}
\hline $\begin{array}{c}\text { Aminoácidos } \\
\text { Essenciais }\end{array}$ & $\begin{array}{c}\text { Silagem } \\
\text { biológica }\end{array}$ & $\begin{array}{c}\text { Silagem } \\
\text { ácida }\end{array}$ & $\begin{array}{c}\text { Silagem } \\
\text { enzimática }\end{array}$ & $\begin{array}{c}\text { Peixe* } \\
\text { (farinha) }\end{array}$ & $\begin{array}{c}\text { Soja* } \\
\text { (farelo) }\end{array}$ \\
\hline Valina & 4,30 & 5,40 & 5,87 & 5,90 & 4,98 \\
Metionina & 5,62 & 4,34 & 4,35 & 2,43 & 1,09 \\
Isoleucina & 3,64 & 6,46 & 4,35 & 4,80 & 4,88 \\
Leucina & 7,28 & 7,00 & 6,52 & 7,22 & 7,62 \\
Treonina & 4,96 & 4,08 & 4,13 & 4,40 & 3,94 \\
Fenilalanina & 3,97 & 4,10 & 4,35 & 5,22 & 5,05 \\
Lisina & 7,28 & 6,65 & 6,35 & 8,69 & 6,31 \\
Histidina & 2,98 & 2,80 & 2,61 & 2,07 & 2,53 \\
Arginina & 5,62 & 5,80 & 5,87 & 6,59 & 8,12 \\
Triptofano & 0,73 & 0,72 & 0,78 & 0,63 & 1,41 \\
\hline
\end{tabular}

*Fonte: Portz (2001)

Com base nesta tabela verificamos que as silagens ácida, biológica e enzimática apresentaram maiores valores para metionina e histidina e menores valores para a fenilalanina e arginina com relação à farinha de peixe e farelo de soja. As silagens apresentaram maiores teores de triptofano que a farinha de peixe, porém estes foram menores que o apresentado pelo farelo de soja.

Podemos ainda observar que quando os teores de AAE foram expressos em $\mathrm{g} / 100 \mathrm{~g}$ de proteína bruta, os valores obtidos pela silagem biológica apresentaram-se em alguns casos, superiores aos obtidos pelas demais silagens, fato não observado na Tabela 4, na qual os resultados foram expressos em $\mathrm{g} / 100 \mathrm{~g}$ de matéria seca.

Os escores químicos das silagens foram determinados usando como padrão as exigências em AAE (g/100g de proteína bruta) para a tilápia do Nilo, estabelecidos pelo 
National Research Council - NRC (1993). Estes resultados estão apresentados na Tabela 6.

Tabela 6. Escore químico dos aminoácidos essenciais das silagens biológica, ácida e enzimática comparados com as exigências em aminoácidos essenciais para a tilápia do Nilo segundo NRC (1993).

\begin{tabular}{lcccc}
\hline \multirow{2}{*}{ Aminoácidos } & \multicolumn{3}{c}{ Silagem } & \\
\cline { 2 - 4 } Triptofano & Ácida & Biológica & Enzimática & NRC* \\
Lisina & 0,72 & 0,73 & 0,79 & 1,00 \\
Histidina & 1,30 & 1,42 & 1,24 & 5,12 \\
Arginina & 1,63 & 1,73 & 1,52 & 1,72 \\
Treonina & 1,38 & 1,34 & 1,40 & 4,20 \\
Valina & 1,09 & 1,32 & 1,10 & 3,75 \\
Metionina & 1,93 & 1,53 & 2,10 & 2,80 \\
Isoleucina & 1,62 & 2,10 & 1,62 & 2,68 \\
Leucina & 2,07 & 1,17 & 1,40 & 3,11 \\
Fenilalanina+Tirosina & 1,79 & 1,85 & 1,92 & 3,39 \\
\hline
\end{tabular}

*Fonte: National Research Council (1993)

Escore químico $=\underline{(\mathrm{g} \text { de aa/100g da proteína teste })}$ ( $\mathrm{g}$ de aa/100g da proteína padrão)

Podemos, com base nestes resultados (Tabela 6), verificar que todas as silagens apresentaram-se deficientes em triptofano quando comparadas às exigências em aminoácidos essenciais para a tilápia do Nilo, segundo o NRC (1993), corroborando os resultados obtidos por Vidotti et al. (2003) com as silagens ácida e biológica de tilápia. De acordo com Arason (1994) e Raa \& Gilberg (1982), há indicações de que o triptofano seja instável em condições ácidas quando se apresenta na forma livre, sendo 
assim, ele é aparentemente o primeiro aminoácido a se tornar limitante nas silagens de pescado.

Segundo Tacon (1994), considera-se como aminoácido limitante apenas os que estiverem 30\% abaixo das exigências mínimas. Tomando-se este fato como base, as silagens elaboradas neste estudo não apresentam deficiência em nenhum aminoácido essencial.

Porém, como a silagem é apenas um dos ingredientes que farão parte de uma dieta balanceada, essa "limitação" em triptofano não é tida como problema. Como podese observar na Tabela 5, o farelo de soja apresenta um valor elevado para este aminoácido.

Vários autores (Fagbenro, 1994, Fagbenro \& Jauncey, 1995a; Fagbenro \& Bello-Olusoji, 1997, Vidotti, 2001) realizaram em suas pesquisas uma secagem conjunta da silagem com alguns subprodutos agrícolas, normalmente empregados na alimentação animal, com os objetivos de diminuir o teor de umidade, facilitando sua inclusão em rações e de melhorar o perfil de aminoácidos da silagem. Entre os vários produtos utilizados nesta secagem conjunta, o farelo de soja, na proporção de 1:1, com a silagem de pescado é o que vem apresentando melhores resultados de desempenho e digestibilidade em experimentos com peixes.

Mesmo que diversos autores (Fagbenro, 1994; Fagbenro \& Jauncey, 1998; Goddard \& Al-Yahyai, 2001; Neethiselvan et al., 2001; Vidotti, 2001; Vidotti et al., 2003) tenham realizado pesquisas mostrando o potencial da silagem de pescado, como provável substituta parcial da farinha de peixe na alimentação de organismos aquáticos, devido a escassez e alto preço deste insumo no mercado mundial, ela não tem sido amplamente utilizada e um dos motivos é a falta de padronização. De acordo com Raa \& Gilberg (1982), para que a silagem seja efetivamente utilizada como ingrediente em rações animais é necessário que haja uma padronização na composição e na qualidade do produto final.

Esta exigência pode ser futuramente facilitada em decorrência do aumento da participação da aqüicultura, principalmente intensiva, na produção do pescado (Valenti, 2000), fornecendo um produto mais homogêneo quanto à composição, devido a 
padronização da alimentação com o uso de rações balanceadas e, quanto ao tamanho, facilitando o ajuste dos equipamentos pelas indústrias beneficiadoras.

\subsection{Conclusões}

As silagens preparadas nesta pesquisa apresentaram teores elevados de proteína bruta, semelhantes aos da matéria-prima utilizada para a elaboração das mesmas.

As silagens apresentaram todos os AAE com pequenas limitações para o triptofano, constatação que não compromete o valor nutricional das mesmas, já que a silagem é apenas um dos ingredientes que irá compor uma ração balanceada.

Os resultados obtidos pela SA e SE foram, de maneira geral, próximos e melhores que os obtidos pela SB. Recomendamos, com base nos resultados, o uso da SA pela facilidade na sua elaboração.

De uma forma geral podemos concluir que todas as silagens apresentam-se potencialmente viáveis para serem usadas em rações balanceadas para peixes.

\subsection{Referências bibliográficas}

ARASON, S. Production of fish silage. In: MARTIN, A.M. Fisheries processing. London: Chapman and Hall, 1994. p.245-245.

ASSOCIATION OF OFFICIAL ANALYTICAL CHEMISTS. Official methods of analysis. 14.ed. Washington, 1984. 1141p.

BACKHOFF, H.P. Some chemical changes in fish silage. Journal of Food Technology, v.11, n.4, p.353-363, 1976.

BERENZ, Z. Utilización del ensilado de residuos de pescado en pollos. http://www.fao.org/waicent/faoinfo/agricult/aga/agap/aph134/cap2.htm. 1994. 11p. (25 fev. 2003) 
BRASIL. Ministério da Agricultura e Abastecimento. Departamento de Fiscalização e Fomento Animal. Compêndio brasileiro de alimentação animal. Brasília, 1998. $120 \mathrm{p}$.

BROWN, N.; SUMMER, J. Fish silage. In: RELLY, A. Spoilage of tropical fish and products development. Roma: FAO, 1985. p.404-413.

COELLO, N.; BRITO, L.; NONUS, M. Biosynthesis of L-lysine by Corynebacterium glutamicum grown on fish silage. Bioresource Technology, v.73, p.221-225, 2000.

DAPKEVICIUS, M.L.E.; BAPTISTA, I.; NOUT, M.J.R. et al. Lipid and protein changes during the ensilage of blue whiting (Micromesistius poutassou Risso) by acid and biological methods. Food Chemistry, v.63, n.1, p.97-102, 1998.

DAPKEVICIUS, M.L.E.; NOUT, R.M.J.; ROMBOUTS, F.M. et al. Biogenic amine formation and degradation by potencial fish silage starter microorganisms. International Journal of Food Microbiology, v.57, p.107-114, 2000.

DISNEY, J.G.; TATTERSON, I.N.; OLLEY, J. Recent developments in fish silage. In: CONFERENCE ON THE HANDLING, PROCESSING AND MARKETING OF TROPICAL FISH, London, 1976. Proceedings. London: Ministry of Oversea Development, 1977. p.321- 340 .

ESPE, M.; LIED, E. Fish silage prepared from different cooked and uncooked raw materials: chemical changes during storage at different temperatures. Journal of the Science of Food and Agriculture, v.79, p.327-332, 1999.

ESPE, M.; RAA, J.; NJAA, L.R. Nutritional value of stored fish silage as a protein source for young rats. Journal of the Science of Food and Agriculture, v.49, p.259-270, 1989. 
ESPÍNDOLA FILHO, A. Aproveitamento de resíduos sólidos de pescado como fertilizante marinho. São Paulo, 1997. 98p. Dissertação (Mestrado) - Universidade Machenzie.

ESPÍNDOLA FILHO, A. Aproveitamento do resíduo sólido de peixe, camarão e bivalves como ingrediente de ração para aqüicultura. São Paulo, 1999. 224p. Tese (Doutorado) - Universidade Mackenzie.

FAGBENRO, O. Dried fermented fish silage in diets for Oreochromis niloticus. The Israeli Journal of Aquaculture, v.46, n.3, p.140-147, 1994.

FAGBENRO, O. Preparation, properties and preservation of lactic acid fermented shrimp heads. Food Research International, v.27, n.7, p.595-599, 1996.

FAGBENRO, O.; JAUNCEY, K. Water stability, nutrient leaching and nutritional properties of moist fermented fish silage diets. Aquacultural Engineering, v.14, p.143-153, 1995a.

FAGBENRO, O.; JAUNCEY, K. Physical and nutritional properties of moist fermented fish silage pellets as a protein supplement for tilapia (Oreochromis niloticus). Animal Feed Science and Technology, v.71, p.11-18, 1998.

FAGBENRO, O.; BELLO-OLUSOJI, O.A. Preparation, nutrient composition and digestibility of fermented shrimp head silage. Food Chemistry, v.60, p.489-493, 1997.

FAO. Feeding pigs in the tropics. FAO Animal Production and Health, n.132. http://www.fao.org (24 Jan. 2003) 
GODDARD, J.S.; AL-YAHYAI, D.S.S. Chemical and nutritional characteristics of dried sardine silage. Journal of Aquatic Food Product Technology, v.10, n.4, p.39-50, 2001.

GUZMÁN, J.M.; VIANA, M.T. Growth of abalone Haliotis fulgens fed diets with and without fish meal, compared to a commercial diet. Aquaculture, v.165, p.321-331, 1998.

HAARD, M.F.; KARIEL, N.; HERZBERG, G. et al. Stabilization of protein and oil fish in silage for use as a ruminant feed supplements. Journal of the Science of Food and Agriculture, v.36, n.4, p.229-241, 1985.

HAMMOUMI, A.; FAID, M.; EL-YACHIOUI, M.; AMAROUCH, H. Characterization of fermented fish waste used in feeding trials with broilers. Process Biochemistry, v.33, n.4, p.423-427, 1998.

HARDY, R.W.; SHEARER, K.P.; STONE, F.E. WIEG, D.H. Fish silage in aquaculture diets. Journal of World Mariculture Society, v.14, p.695-703, 1983.

HARTMAN, L.; LAGO, R.C.A. Rapid preparation of fatty acid methyl esters from lipids. Laboratory Practice, v.22, p.475-477, 1973.

HASSAN, T.E; HEATH, J.L. Chemical and nutritive characteristics of fish silage produced by biological fermentation. Biological Wastes, v.20, n.3, p.187-201, 1987.

HONCZARYK, A.; MAEDA, L.S. Crescimento do pirarucu, Arapaima gigas, utilizando dieta à base de ensilado biológico de pescado. In: SIMPÓSIO BRASILEIRO DE AQÜICULTURA, 10., Recife, 1998. Anais. Recife: Persona, 1998. v.2, p.93-100. 
HOSSAIN, M.A.; NAHAR, N.; KAMAL, M. Nutrient digestibility coefficients of some plant and animal proteins for rohu (Labeo rohita). Aquaculture, v.151, p.37-45, 1997.

HUSSAIN, R.A.K.; OFFER, N.W. Effect of folmaldehyde treatment on the degradation of acid-preserved fish silage protein in vitro. Animal Feed Science and Technology, v.16, p.297-304, 1987.

JACKSON, A.J.; KERR, A.K.; COWEY, C.B. Fish silage as a dietary ingredient for salmon. I. Nutritional and storage characteristics. Aquaculture, v.38, p.211-220, 1984a.

JACKSON, A.J.; KERR, A.K.; BULLOCK, A.M. Fish silage as a dietary ingredient for salmon. II. Preliminary growth findings and nutritional pathology. Aquaculture, v.40, p.283-291, $1984 b$.

JOHNSON, R.J.; BROWN, N.; EASON, P.; SUMMER, J. The nutritional quality of two types of fish silage for broiler chickens. Journal of the Science of Food and Agriculture, v.36, p.1051-1056, 1985.

KOMPIANG, I.P. Fish silage: its prospect and future in Indonesia. Indonesia Agriculture Research \& Development Journal, v.3, n.1, p.9-12, 1981.

MAIA, W.M.; NUNES, M.L.; FIGUEIREDO, M.J.; BRAGAGNOLO, N. Caracterização da fração lipídica de silagem de resíduos de tilápia para utilização em rações para a aqüicultura. In: SIMPÓSIO BRASILEIRO DE AQUICULTURA, 10., Recife, 1998. Anais. Recife: Persona, 1998.v.2, p.55-64.

MOORE, I; STEIN, W.H. Chromatographic determination of amino acids by use of automatic recording equipaments. Methods in Enzymology, v.6, p.919-931, 1963. 
MORALES-ULlOA, D.F. Bioconversão de resíduos da indústria pesqueira. Piracicaba, 1994. 127p. Dissertação (Mestrado) - Escola Superior de Agricultura "Luiz de Queiroz", Universidade de São Paulo.

MORALES-ULLOA, D.F.; OETTERER, M. Bioconversão de resíduos da indústria pesqueira. Ciência e Tecnologia de Alimentos, v.15, n.3, p.206-214, 1995.

MORALES-ULLOA, D.F.; OETTERER, M. Composição em aminoácidos de silagens químicas, biológicas e enzimáticas preparadas com resíduos de sardinha. Ciência e Tecnologia de Alimentos, v.17, n.3, p.252-258, 1997.

NATIONAL RESEARCH COUNCIL. Nutrient requirements of fish. Washington: National Academy Press, 1993. 115p.

NEETHISELVAN, N.; JASMINE, G.I.; MANIKANDAVELU, D.; VENKATARAMANI, V.K. Use of fermented fish ensilage in the diets of Etroplus suratensis (Bloch). Fishery Technology, v.38, n.1, p.43-47, 2001.

NELSON, D.L.; COX, M.M. Lehninger principles of biochemistry. New York: Worth Publication, 2000. 145p.

NUNES, M.L. Silagem de pescado. In: OGAWA, M.; MAIA, E.L. Manual de pesca. São Paulo: Livraria Varela, 1999. p.371-379.

OLIVEIRA, A.M.B.M.S. Substituição de fontes protéicas de origem animal por fontes protéicas de origem vegetal em rações para o "Black bass" Micropterus salmooides. Piracicaba, 2003. 103p. Tese (Doutorado) - Escola Superior de Agricultura "Luiz de Queiroz”, Universidade de São Paulo. 
OTTATI, M.; GUTIERREZ, M.; BELLO, R. Estudio sobre la elaboración de ensilado microbiano a partir de pescado proveniente de especies subutilizadas. Archivos Latinoamericanos de Nutrición, v.4, n.3, p.408-425, 1990.

PARÍN, M.A.; ZUGARRAMURDI, A. Aspectos económicos del procesamiento y uso de ensilado de pescado. http://www.fao.org/waicent/faoinfo/agricult/aga/cap4.htm. 1994. 16p. (25 fev. 2003)

PORTZ, L. Utilização de diferentes fontes protéicas em dietas formuladas pelo conceito de proteína ideal para o "black bass" (Micropterus salmoides). Piracicaba, 2001a. 111p. Tese (Doutorado) - Escola Superior de Agricultura "Luiz de Queiroz", Universidade de São Paulo.

RAA, J.; GILDBERG, A. Fish silage: a review. Journal of the Food Science and Nutrition, v.61, p.383-419, 1982.

RISTIC, M.D.; FILIPOVIC, S.S.; SAKAC, M.L.J. Liquid protein feedstuffs from freshwater fish by-products as a component of animal feed. Romanian Biotechnological Letters, v.7, n.3, p.729-736, 2002.

RIVERO, L.E.; VIANA, M.T. Effect of $\mathrm{pH}$, water stability and toughness of artificial diets on the palatability for juvenile abalone, Haliotis fulgens. Aquaculture, v.144, p.353-362, 1996.

SALES, R.O. Processamento, caracterização química e avaliação nutricional da silagem da despesca da tilápia do Nilo (Oreochromis niloticus) em dietas experimentais com ratos. Campinas, 1995. 174p. Tese (Doutorado) - Faculdade de Engenharia de Alimentos, Universidade Estadual de Campinas. 
SAMUELS, W.A.; FONTENOT, J.P.; ALLEN, V.G.; ABAZINGE, M.D.A. Seafood processing wastes ensiled with straw: utilization and intake by sheep. Journal of Animal Science, v.69, p.4983-4992, 1991.

SAS INSTITUTE. SAS user's guide: statistics. 5.ed. Cary, 1985. 365p.

SGARBIERI, V.C. Alimentação e nutrição: fator de saúde e desenvolvimento. Campinas: UNICAMP, 1987. 387p.

SHIRAI, K.; GUERRERO, I.; HUERTA, S. et al. Effect of initial glucose concentration and inoculation level of lactic acid bacteria in shrimp waste ensilation. Enzyme and Microbial Technology, v.28, p.446-452, 2001.

SPIES, J.R. Determination of tryptophan in proteins. Analytical Chemistry, v.39, p.1412-1415, 1967.

STONE, F.E.; HARDY, R.W. Nutritional value of acid stabilised silage and liquefied fish protein. Journal of the Science of Food and Agriculture, v.37, p.797-803, 1986.

STONE, F.E.; HARDY, R.W.; SHEARER, K.D.; SCOTT, T.M. Utilization of fish silage by rainbow trout (Salmo gairdineri). Aquaculture, v.76, p.109-118, 1989.

STROM, T.; EGGUM, R.W. Nutritional value of fish viscera silage. Journal of the Science of Food and Agriculture, v.32, p.115-120, 1981.

TACON, A.G.J. Feed ingredients for carnivorous fish species: alternatives to fish meal and other fisheries resources. Roma: FAO, 1994. (FAO Fisheries Circular, 881) 
TATTERSON, J.N.; WINDSOR, M.L. Fish silage. Journal of the Science of Food and Agriculture, v.25, n.4, p.369-379, 1974 .

TOCHER, D.R.; MOURENTE, G.; SARGENT, J.R. The use of silages prepared from fish neural tissues as enrichers for rotifers (Brachionus plicatilis) and Artemia in the nutrition of larval marine fish. Aquaculture, v.148, p.213-231, 1997.

VALENTI, W.C. Aquaculture for sustainable development. In: VALENTI, W.C.; POLI, C.R.; PEREIRA, J.A.; BORGHETTI, J.R. Aqüicultura no Brasil. Brasília: CNPq/Mistério da Ciência e Tecnologia, 2000. p.17-24.

VALÉRIO, A.C.R. Elaboração de silagem enzimática de pescado como alternativa ao processo tradicional. Piracicaba, 1994. 102p. Dissertação (Mestrado) - Escola Superior de Agricultura "Luiz de Queiroz", Universidade de São Paulo.

VIANA, M.T.; GUZMAN, J.M.; ESCOBAR, R. Effect of heated and unheated fish silage as a protein source in diets for abalone Haliotis fulgens. Journal of the World Aquaculture Society, v.30, n.4, p.481-489, 1999.

VIDOTTI, R.M. Produção e utilização de silagens de peixe na nutrição do pacu (Piaractus mesopotamicus). Jaboticabal, 2001. 65p. Tese (Doutorado) - Centro de Aqüicultura, Universidade Estadual Paulista “Júlio de Mesquita Filho”.

VIDOTTI, R.M.; VIEGAS, E.M.M.; CARNEIRO, D.J. Amino acid composition of processed fish silage using diferent raw materials. Animal Feed Science and Technology, v.105, p.199-204, 2003.

VIZCARRA-MAGAÑA, L.A.; AVILA, E.; SOTELO, A. Silage preparation from tuna fish wastes and its nutritional evaluation in broilers. Journal of the Science of Food and Agriculture, v.79, p.1915-1922, 1999. 
ZAHAR, M.; BENKERROUM, N.; GUEROUALI, A. et al. Effect of temperature, anaerobiosis, stirring and salt addition on natural fermentation silage of sardine and sardine wastes in sugarcane molasses. Bioresource Technology, v.82, p.171-176, 2002. 


\section{COEFICIENTE DE DIGESTIBILIDADE APARENTE DA ENERGIA E DOS NUTRIENTES DAS SILAGENS ÁCIDA, BIOLÓGICA E ENZIMÁTICA PELA TILÁPIA DO NILO (Oreochromis niloticus) = THE APPARENT DIGESTIBILITY COEFFICIENT OF THE ENERGY AND NUTRIENTS OF ACID, BIOLOGICAL AND ENZYMATIC SILAGE FOR NILE TILÁPIA (Oreochromis niloticus)}

\subsection{Resumo}

A utilização da silagem de pescado como substituto de ingredientes protéicos em rações para organismos aquáticos surge como alternativa para solucionar os problemas de ordem sanitária e ambiental causados pela falta de destino adequado dos resíduos gerados pela indústria do pescado, além de diminuir os custos com alimentação e conseqüentemente os custos de produção do pescado, já que os gastos com a alimentação correspondem a aproximadamente $60 \%$ do custo total. A digestibilidade aparente é uma das principais ferramentas para avaliar o potencial do ingrediente a ser utilizado em rações para peixes. Este trabalho teve por objetivo determinar os coeficientes de digestibilidade aparente (CDA) da energia, nutrientes e aminoácidos da silagem ácida (SA), silagem biológica (SB) e silagem enzimática (SE) pela tilápia do Nilo (Oreochromis niloticus) com peso médio de 94,54 \pm 12,66g. Foram encontrados valores de energia digestível de: 4041,32; 3663,95 e 3394,20 Kcal/kg para SA, SB e SE,

respectivamente. Foram obtidos valores de CDA de: 92,01; 89,09 e 93,66\% para proteína bruta, 89,$86 ; 87,61$ e 90,10\% para cinza, 82,52; 78,98 e 82,96\% para matéria seca, 81,$72 ; 73,99$ e $80,27 \%$ para cálcio e 77,$86 ; 79,21$ e $81,46 \%$ para o fósforo na SA, 
SB e SE, respectivamente. O CDA médio dos aminoácidos foi de: 91,83; 90,76 e $94,61 \%$ para SA, SB e SE, respectivamente. Os resultados obtidos demonstram a possibilidade da utilização da SA, SB e SE como ingrediente protéico em rações balanceadas para aqüicultura, como substituto parcial da farinha de peixe.

\subsection{Summary}

The use of the fish silage as substitute of protein ingredients in feed for aquatic organisms is an alternative to solve sanitary and environmental problems caused by the lack of an adequate destination for the residues generated by the fishing industry. It would also lower the costs with feed, and consequently the fish production costs, since the expenses with the feed account for approximately $60 \%$ of the total cost. Apparent digestibility is one of the main tools to evaluate the potential of an ingredient to be used in fish foods. Based on this, this work had the objective of determining the apparent digestibility coefficients (ADC) of the energy, nutrients and amino acids of acid silage (AS), biological silage (BS) and enzymatic silage (ES) for the Nile tilapia (Oreochromis niloticus) with average weight $94.54 \pm 12.66 \mathrm{~g}$. The digestible energy values found were: $4041.32 ; 3663.95$ and $3394.20 \mathrm{Kcal}_{\mathrm{Kg}}{ }^{-1}$ for AS, BS and ES, respectively. ADC values were: $92.01 ; 89.09$ and $93.66 \%$ for raw protein, $89.86 ; 87.61$ and $90.10 \%$ for ash, 82.52; 78.98 and $82.96 \%$ for dry matter, 81.72; 73.99 and $80.27 \%$ for calcium and 77.86; 79.21 and $81.46 \%$ for phosphor for AS, BS and ES, respectively. The average ADC of amino acids was: 91.83; 90.76 and $94.61 \%$ for AS, BS and ES, respectively.

The results demonstrate the possibility for the use of AS, BS and ES as a protein ingredient in balanced feed for the fishing industry as a partial substitute of fish meal.

\subsection{Introdução}

$\mathrm{Na}$ década de 90 a aqüicultura foi a única atividade relacionada com a produção de alimentos que cresceu em ritmo superior a $10 \%$ ao ano e por isso vem 
ganhando importância como produtora de proteína animal (Castagnolli, 1997; Giulietti et al., 1996). Esta atividade deverá assumir a responsabilidade pelo suprimento do déficit da demanda de pescado, uma vez que a pesca extrativa, tanto de mar quanto de águas interiores, situa-se abaixo da metade do potencial com tendência a estabilização ou queda (Valenti, 2000).

O crescimento da aqüicultura, associado ao aumento de práticas de cultivo cada vez mais intensivas, gerou aumento na procura por ingredientes de alta qualidade (Espe et al., 1999), que permitam formular dietas de alto valor nutricional, economicamente viáveis e ambientalmente corretas (Portz, 2001).

Como em qualquer criação zootécnica, na piscicultura, a prática da alimentação corresponde a um alto percentual dos custos operacionais, podendo atingir índices que variam em torno de 40 a $60 \%$, onde os ingredientes protéicos são responsáveis pela maior parte desse custo (El-Sayed, 1999; Cheng et al., 2003)

Devido ao seu alto valor biológico, equilíbrio em aminoácidos e ácidos graxos, altos níveis de cálcio e fósforo e vitaminas lipo e hidrossolúveis, a farinha de peixe é considerada a principal fonte de proteína dietética em rações para peixes que proporciona o máximo desempenho (Pezzato, 1995; Sales \& Britz, 2003).

Estudos mostram progressiva escassez da farinha de peixe no mercado mundial e, conseqüente, aumento relativo em seu preço. Com isso, a produção de ração comercial de qualidade para a aqüicultura dependerá, em um futuro próximo, da elaboração de produtos adequados para substituição da farinha de peixe, tanto no aspecto nutricional quanto de custo (Nogueira Júnior et al., 1997).

Assim sendo, nos últimos anos diversas pesquisas vêm sendo realizadas no sentido de identificar fontes protéicas alternativas, disponíveis nas regiões de criação, como substitutos parciais ou totais da farinha de peixe, permitindo assim a redução nos custos com alimentação (Espe et al., 1999; Fontaínhas-Fernandes et al., 1999; Furuya, 2000; Furuya et al., 2001; Portz, 2001; Stone et al., 2000).

O valor nutricional de um alimento não deve ser somente baseado na sua composição química, mas também na quantidade de nutrientes ou energia que o peixe pode absorver (Furuya, 2000). Portanto, a determinação do coeficiente de digestibilidade 
aparente, do ingrediente a ser utilizado numa dieta balanceada para peixes, é importante para a avaliação do potencial de utilização deste (Allan et al., 2000; Goddard \& McLean, 2001).

Os resíduos de origem animal representam vasta fonte de energia e de nutrientes, que podem ser convertidos em ingredientes para a indústria de alimentação animal. Uma alternativa de grande potencial é o aproveitamento das perdas na captura e resíduos do processamento do pescado na elaboração do ensilado de peixe, produto de alto valor biológico (Honczaryck \& Maeda, 1998; Parín \& Zugarramurdi, 1994; Vidotti et al., 2002).

A silagem de pescado se constitui em um produto líquido ou semi-líquido, produzido a partir do pescado inteiro ou partes dele, preservado pela adição de ácidos (silagem ácida) ou por fermentação microbiana induzida por carboidratos (silagem biológica) (Kompiang, 1981). No processo de ensilagem, as proteínas são hidrolisadas pelas enzimas naturalmente presentes e/ou adicionadas (silagem enzimática), processo favorecido pelo ajuste do $\mathrm{pH}$, originando um produto rico em proteínas, peptídeos de cadeia curta e aminoácidos livres (Stone \& Hardy, 1986; Valério, 1994).

O grau de hidrólise pode ser usado como critério químico para avaliar a qualidade da silagem de pescado (Espe et al., 1989; Espe \& Lied, 1999). Segundo Stone et al. (1989), o valor nutricional da silagem pode ser significantemente aumentado, limitando a hidrólise das proteínas e polipeptídeos em aminoácidos livres. Os mesmos autores citam que, assim como em humanos, os peptídeos de cadeia curta (di e tripeptídeos) são melhores e mais absorvidos, pelos peixes, que os aminoácidos livres.

Vários autores vêm ressaltando o alto coeficiente de digestibilidade da silagem de pescado em experimentos com diversas espécies de peixes, mostrando a viabilidade econômica do uso dessa fonte, além do benefício ambiental, pois o resíduo de pescado descartado resultaria em matéria poluente (Fagbenro, 1994; Fagbenro \& Jauncey, 1995a, 1995b; Goddard \& Al-Yahyai, 2001; Vidotti et al., 2002).

É de grande relevância a inserção do aproveitamento de resíduos na cadeia produtiva de pescado, com intuito de evitar desperdícios, reduzir os custos de produção do pescado e a poluição ambiental, pois com a criação de alternativas tecnológicas, 
teremos como resultado a geração de empregos e o caminho para o desenvolvimento sustentado (Espíndola Filho, 1997).

O presente trabalho teve por objetivo determinar os coeficientes de digestibilidade aparente (CDA) dos nutrientes, energia, cálcio, fósforo e aminoácidos das silagens ácida, biológica e enzimática, pela tilápia do Nilo (Oreochromis niloticus).

\subsection{Material e métodos}

\subsubsection{Matéria-prima}

A matéria-prima utilizada para a elaboração das silagens era formada de aproximadamente $20 \%$ de resíduos de tilápias do Nilo (Oreochromis niloticus) do processamento (filetagem) conduzido no Departamento de Agroindústria, Alimentos e Nutrição da ESALQ-USP, constituído de cabeças, vísceras, escamas, nadadeiras, coluna vertebral, pele e tecidos aderidos e de, aproximadamente, $80 \%$ de tilápias do Nilo inteiras (descarte), provenientes do Setor de Piscicultura do Departamento de Produção Animal da ESALQ-USP. Este material foi moído em equipamento elétrico modelo ML4.0/Weg- $\mu$ line, transformando-se numa massa homogênea, totalizando $60 \mathrm{~kg}$.

\subsubsection{Silagem ácida}

A massa homogênea obtida como em 2.1, foi dividida igualmente em seis recipientes de plástico. Cada recipiente recebeu $10 \mathrm{~kg}$ da massa homogênea, 200ppm de BHT (Butil Hidroxi Tolueno), dissolvido em álcool etílico e 3\% (volume/peso) de uma mistura de ácido fórmico a 88\% e ácido propiônico a 100\%, na proporção de 1:1.

A massa foi revolvida manualmente, com o auxílio de espátula, visando acidificação homogênea; posteriormente, os recipientes foram fechados com tampas plásticas e mantidos ao ambiente.

A silagem ácida constituiu-se num pré-tratamento para a produção das demais silagens. Dos 6 recipientes, 2 foram mantidos como silagem ácida por 4 semanas e os demais foram destinados aos tratamentos biológico e enzimático. 


\subsubsection{Silagem biológica}

A silagem biológica foi preparada a partir da silagem ácida, decorridos 3 dias do tempo inicial, quando foi removida a camada lipídica sobrenadante.

Foram utlizados 2 recipientes com $10 \mathrm{~kg}$ de silagem ácida cada (prétratamento) e em cada um, foram adicionados $0,014 \%(\mathrm{p} / \mathrm{p})$ de solução inóculo de Lactobacillus plantarum (descrito no item 2.4.) e 18\% (p/p) de melaço de cana, proveniente da Usina Santa Elisa, SP, na forma de pó com 4\% de umidade e diluído em água destilada até atingir aproximadamente $24 \%$ de umidade. A massa foi revolvida manualmente com espátula, os recipientes foram fechados com tampas plásticas e mantidos ao ambiente por 3 semanas.

\subsubsection{Obtenção da solução inóculo}

Erlenmeyers de $500 \mathrm{~mL}$ contendo o meio inoculo (obtido conforme item 3.4.4 do capítulo anterior), com concentrações de pelo menos $10^{8}$ células $/ \mathrm{ml}$ de Lactobacillus plantarum, foram utilizados para a obtenção da solução inóculo. Este material contendo os microrganismos foi centrifugado em uma centrífuga modelo BHG - Hermle/Z320 $(4000 \mathrm{xG})$ a $25^{\circ} \mathrm{C}$ por 15 minutos para a separação da massa de células.

As massas de células centrifugadas foram suspensas em solução salina a $0,85 \%$ até completar $40 \mathrm{~mL}$. O material obtido (células suspensas + solução salina) foi chamado de solução inóculo (Morales-Ulloa \& Oetterer, 1995).

\subsubsection{Silagem enzimática}

A silagem enzimática foi preparada a partir da silagem ácida, decorridos 3 dias do tempo inicial, quando foi removida a camada lipídica sobrenadante.

Foram utlizados 2 recipientes com $10 \mathrm{~kg}$ de silagem ácida (pré-tratamento). A cada um dos recipientes foram adicionados $10 \mathrm{~g}$ da enzima protease, tipo II de Aspergillus oryzae, com 0,13 unidades/mg de sólidos, produzida pela Sigma Chemical Corporation, diluída em $100 \mathrm{~mL}$ de água destilada, segundo Valério (1994). A massa foi revolvida manualmente com espátula, os recipientes foram fechados com tampas plásticas e mantidos ao ambiente por uma semana. 


\subsubsection{Análises químicas}

As análises químico-bromatológicas das silagens e da matéria-prima foram realizadas com base na matéria seca de acordo com os procedimentos da AOAC (1984), sob a padronização do Compêndio Brasileiro de Nutrição Animal (BRASIL, 1998). A umidade foi determinada através do método gravimétrico, em estufa a $105^{\circ} \mathrm{C}$ até peso constante. $\mathrm{O}$ teor de cinza foi determinado pelo método gravimétrico, em mufla a $550^{\circ} \mathrm{C}$ e incineração da matéria orgânica em bico de Bunsen. O teor de proteína bruta foi determinado pelo método de micro-Kjedahl e o extrato etéreo foi determinado após extração com éter de petróleo pelo método de Soxhlet. Os teores de cálcio, fósforo e óxido de cromo foram quantificados por espectrofotometria de absorção atômica, após digestão ácida pelo laboratório CBO Assessoria \& Análise, localizado em Campinas, São Paulo.

\subsubsection{Análise dos aminoácidos}

As amostras foram analisadas por cromatografia líquida, em colunas de resinas de troca catiônica e derivação pós-coluna com ninhidrina, em auto analisador. Para a quantificação dos aminoácidos, as amostras foram hidrolisadas com $\mathrm{HCl} 6 \mathrm{~N}$, por 22 horas a $110^{\circ} \mathrm{C}$, de acordo com método descrito por Moore \& Stein (1963).

$\mathrm{O}$ triptofano foi determinado após hidrólise enzimática com pronase a $40^{\circ} \mathrm{C}$ por 24 horas, seguido de reação colorimétrica com 4-Dimetil-Amino-Benzaldeído (DAB) em ácido sulfúrico $21,2 \mathrm{~N}$ e leitura a $590 \mathrm{~nm}$. O teor de triptofano foi calculado a partir de uma curva padrão, segundo Spies (1967).

As análises foram realizadas pelo laboratório CBO Assessoria \& Análise, localizado em Campinas, São Paulo.

\subsubsection{Determinação do coeficiente de digestibilidade aparente}

O estudo foi realizado no Laboratório de Nutrição de Organismos Aquáticos (AquaNutri) da FMVZ/UNESP- Câmpus de Botucatu- SP., unidade integrada ao Centro de Aqüicultura da UNESP (CAUNESP). 
A determinação do coeficiente de digestibilidade aparente (CDA) foi feita pelo método indireto, utilizando ração marcada com $0,1 \%$ de óxido de cromo III $\left(\mathrm{Cr}_{2} \mathrm{O}_{3}\right)$. Elaborou-se uma ração referência, purificada com base na proteína da albumina e gelatina (Tabela 1). As rações-teste foram formuladas de forma que cada um dos ingredientes estudados (silagem ácida, silagem biológica e silagem enzimática), substituiu $30 \%$ da ração referência (purificada).

Tabela 1. Composição da ração referência (\% com base na matéria úmida).

\begin{tabular}{|c|c|}
\hline Ingrediente & $\%$ \\
\hline Albumina & 32,00 \\
\hline Gelatina & 7,70 \\
\hline Amido & 44,13 \\
\hline Óleo de soja & 6,00 \\
\hline$\alpha$-celulose & 6,00 \\
\hline Fosfato bicálcico & 3,00 \\
\hline Suplemento mineral e vitamínico ${ }^{1}$ & 0,50 \\
\hline Vitamina $\mathrm{C}^{2}$ & 0,05 \\
\hline Sal comum & 0,50 \\
\hline $\mathrm{BHT}^{3}$ & 0,02 \\
\hline Óxido de cromo III & 0,10 \\
\hline Total & 100 \\
\hline
\end{tabular}

${ }^{1}$ Suplemento vitamínico e mineral (SupreMais): vitA 1200000 UI; vitD 200000 UI; vitE $12000 \mathrm{mg}$; vitK $2400 \mathrm{mg}$; vitB $4800 \mathrm{mg}$; vitB $4800 \mathrm{mg}$; vitB $648000 \mathrm{mg}$; $\mathrm{B}_{12}$ $4800 \mathrm{mg}$; ác. fólico $1200 \mathrm{mg}$; ác. pantotênico $12000 \mathrm{mg}$; vitC $48 \mathrm{mg}$; biotina $48 \mathrm{mg}$; colina 65 mg; niacina 24000 mg; Fe 10000 mg; Cu 600 mg; Mn 4000 mg; Zn 6000 mg; I $20 \mathrm{mg}$; Co $2 \mathrm{mg}$ e Se $20 \mathrm{mg}$;

${ }^{2}$ Vitamina C: sal cálcica 2-monofosfato de ácido ascórbico com $42 \%$ de princípio ativo;

${ }^{3} \mathrm{BHT}=$ Butil Hidroxi Tolueno.

Para a confecção das rações, as silagens estudadas foram secas em estufa a $50^{\circ} \mathrm{C}$ por $24 \mathrm{~h}$ e depois moídas em um moinho de facas. Após a pesagem e homogeneização dos ingredientes, foi acrescida água, a $45^{\circ} \mathrm{C}$, na proporção de $20 \%$ do peso total da ração. A mistura foi peletizada em equipamento modelo ML-4.0/Weg- 
$\mu$ line, e seca em estufa de ventilação forçada $\left(55^{\circ} \mathrm{C}\right)$. Depois de secas, as rações foram trituradas em peletes de 2 a $5 \mathrm{~mm}$ e mantidos em geladeira.

$\mathrm{O}$ experimento foi instalado em oito aquários de alimentação, de formato circular e capacidade de $250 \mathrm{~L}$ e quatro aquários de coleta de fezes, de formato cilindrocônico e capacidade de 300L, em sistema de recirculação. A vazão de abastecimento dos aquários de alimentação realizava uma troca completa a cada uma hora; os aquários de coleta de fezes possuíam sistema de recirculação individual.

A temperatura e o oxigênio dos aquários de digestibilidade e de alimentação foram mantidos através de aquecedores $\left(26^{\circ} \mathrm{C}\right)$ e pedra porosa, acoplada a um aerador central

Os peixes, tilápia do Nilo (Oreochromis niloticus), com peso médio de 94,54 \pm 12,66 g, foram alojados em oito gaiolas circulares, sendo 16 peixes/gaiola, confeccionadas com tela plástica (malha de 1,5 cm entre-nós), com o objetivo de facilitar o manejo e minimizar o estresse durante o processo de transferência entre os aquários.

Os peixes foram mantidos, durante o dia, nos aquários de alimentação, onde receberam refeições à vontade das 8:00 às 17:30 horas, através de arraçoamento manual. Após este período foram transferidos para os aquários de coleta de fezes onde permaneceram até a manhã seguinte.

As fezes foram coletadas, por gravidade, em coletores localizados no final do aquário de coleta, secas em estufa de ventilação forçada a $55^{\circ} \mathrm{C}$, moídas e acondicionadas em refrigeradores $\mathrm{a}-15^{\circ} \mathrm{C}$ para análise posterior.

Os CDA da energia, nutrientes e aminoácidos dos ingredientes testados e da ração referência foram calculados de acordo com a seguinte fórmula:

$$
\mathrm{CDA}(\%)=100-\left[100 \times\left(\frac{\% \mathrm{Cr}_{2} \mathrm{O}_{3} \text { ração }}{\% \mathrm{Cr}_{2} \mathrm{O}_{3} \text { fezes }}\right) \times\left(\frac{\% \text { nutriente ou energia nas fezes }}{\% \text { nutriente ou energia na ração }}\right)\right]
$$

Onde:

$\mathrm{CDA}=$ coeficiente de digestibilidade aparente $(\%)$;

$\% \mathrm{Cr}_{2} \mathrm{O}_{3}$ ração = porcentagem de óxido de cromo na ração;

$\% \mathrm{Cr}_{2} \mathrm{O}_{3}$ fezes $=$ porcentagem de óxido de cromo nas fezes. 
Como o ingrediente testado substituiu $30 \%$ da ração referência (purificada), a digestibilidade aparente, em separado da energia, nutrientes ou aminoácidos, dos ingredientes foi calculada de acordo com a seguinte fórmula:

$$
\mathrm{CDAn}=\frac{\mathrm{CDART}_{\mathrm{R}}-\mathrm{CDARR} \times \mathrm{y}}{\mathrm{z}}
$$

Onde:

CDAn = coeficiente de digestibilidade aparente da energia, nutrientes ou aminoácidos; $\mathrm{CDA}_{\mathrm{RT}}=$ coeficiente de digestibilidade aparente da energia, nutrientes ou aminoácidos na ração teste;

$\mathrm{CDA}_{\mathrm{rr}}=$ coeficiente de digestibilidade aparente da energia, nutrientes ou aminoácidos na ração referência;

$\mathrm{y}=$ proporção da ração referência;

$\mathrm{Z}=$ proporção da ração teste.

Os dados obtidos foram submetidos à análise de variância (ANOVA) e depois submetidos ao teste de comparação de médias Tukey $(\mathrm{P}<0,05)$, pelo aplicativo SAS (1985).

\subsection{Resultados e discussão}

Durante todo o período experimental não houve mortalidade e nem foram observadas alterações no consumo alimentar tanto da ração referência (purificada) quanto das demais que continham os ingredientes testados.

As rações contendo as silagens como ingredientes foram facilmente aceitas pelos peixes, confirmando que os produtos de origem animal, como ocorre com a farinha de peixe, além do valor nutricional, atuam também como atractantes (Furuya, 2001). Na silagem, os aminoácidos que são liberados no processo de hidrólise (aminoácidos livres) agem como atractantes (Berge \& Storebakken, 1996).

Os valores da composição químico-bromatológica e energia, da ração referência (RR), e dos ingredientes testados (base na matéria seca) apresentam-se na Tabela 2, enquanto na Tabela 3 encontram-se a composição em aminoácidos essenciais (AAE) e não essenciais (AANE) da ração referência e ingredientes. 
Tabela 2. Energia e nutrientes da ração referência e das silagens biológica, ácida e enzimática, em g/100g na matéria seca.

\begin{tabular}{lcccc}
\hline Nutriente & $\begin{array}{c}\text { Ração } \\
\text { referência }\end{array}$ & $\begin{array}{c}\text { Silagem } \\
\text { biológica }\end{array}$ & $\begin{array}{c}\text { Silagem } \\
\text { ácida }\end{array}$ & $\begin{array}{c}\text { Silagem } \\
\text { enzimática }\end{array}$ \\
\hline Matéria seca & $96,04 \pm 0,07$ & $34,58 \pm 0,20$ & $25,21 \pm 0,17$ & $25,01 \pm 0,11$ \\
Proteína & $37,70 \pm 0,22$ & $33,00 \pm 0,26$ & $54,25 \pm 0,50$ & $54,50 \pm 0,30$ \\
Lipídio & $6,76 \pm 0,31$ & $12,25 \pm 0,45$ & $12,45 \pm 0,45$ & $12,17 \pm 0,18$ \\
Cinza & $4,90 \pm 0,10$ & $25,07 \pm 0,49$ & $26,62 \pm 0,34$ & $27,17 \pm 0,28$ \\
Energia ${ }^{1}$ & $3641,20 \pm 31,0$ & $4334,50 \pm 34,30$ & $4678,00 \pm 28,00$ & $3809,85 \pm 29,85$ \\
Cálcio & $0,98 \pm 0,02$ & $7,33 \pm 0,04$ & $8,03 \pm 0,08$ & $8,58 \pm 0,05$ \\
Fósforo & $0,75 \pm 0,05$ & $2,86 \pm 0,06$ & $4,71 \pm 0,03$ & $4,85 \pm 0,05$ \\
\hline
\end{tabular}

Nota: média de três repetições \pm erro padrão.

${ }^{1}$ Energia expressa em kcal/kg

$\mathrm{Na}$ Tabela 4, estão apresentados os resultados do coeficiente de digestibilidade aparente $(\mathrm{CDA})$ da matéria seca $\left(\mathrm{CDA}_{\mathrm{MS}}\right)$, proteína bruta $\left(\mathrm{CDA}_{\mathrm{PB}}\right)$, energia bruta $\left(\mathrm{CDA}_{\mathrm{EB}}\right)$, cinza $\left(\mathrm{CDA}_{\mathrm{C}}\right)$, cálcio $\left(\mathrm{CDA}_{\mathrm{Ca}}\right)$ e fósforo $\left(\mathrm{CDA}_{\mathrm{P}}\right)$.

Os resultados da ANOVA revelam que todos os CDA dos nutrientes e energia bruta, da RR e dos ingredientes testados apresentaram diferença entre si $(\mathrm{P}<0,01)$. Os valores dos CDA obtidos nesta pesquisa foram elevados para todos os nutrientes e energia bruta dos ingredientes testados.

Entre os ingredientes testados, a silagem enzimática (SE) apresentou maiores valores para o $\mathrm{CDA}_{\mathrm{MS}}, \mathrm{CDA}_{\mathrm{PB}}, \mathrm{CDA}_{\mathrm{C}}$ e $\mathrm{CDA}_{\mathrm{P}}$. Já na silagem ácida, os maiores valores ocorreram para o $\mathrm{CDA}_{\mathrm{Ca}}$.

Os valores de $\mathrm{CDA}_{\mathrm{MS}}$ encontrados neste estudo, para os três tipos de silagem ficaram próximos aos obtidos por Goddard \& Al-Yahyai (2001), para a tilápia do Nilo (Oreochromis niloticus). Estes autores testaram a digestibilidade da silagem ácida, preparada com sardinha e 1,5\% (v/p) de uma mistura de ácido fórmico e propiônico (1:1), obtendo CDA $\mathrm{MS}_{\mathrm{MS}}$ de $81,90 \pm 0,37 \%$. 
Tabela 3. Aminoácidos da ração referência e das silagens biológica, ácida e enzimática $(\mathrm{g} / 100 \mathrm{~g}$ de matéria seca).

\begin{tabular}{lcccc}
\hline Aminoácidos & $\begin{array}{c}\text { Ração } \\
\text { referência }\end{array}$ & $\begin{array}{c}\text { Silagem } \\
\text { biológica }\end{array}$ & $\begin{array}{c}\text { Silagem } \\
\text { ácida }\end{array}$ & $\begin{array}{c}\text { Silagem } \\
\text { enzimática }\end{array}$ \\
\hline ESSENCIAIS & 1,87 & 1,42 & 2,70 & 2,98 \\
Valina & 1,56 & 1,86 & 2,17 & 2,21 \\
Metionina & 1,67 & 1,20 & 3,23 & 2,21 \\
Isoleucina & 2,60 & 2,41 & 3,50 & 3,31 \\
Leucina & 1,18 & 1,64 & 2,04 & 2,10 \\
Treonina & 1,56 & 1,31 & 2,05 & 2,21 \\
Fenilalanina & 2,19 & 2,41 & 3,33 & 3,22 \\
Lisina & 0,68 & 0,99 & 1,40 & 1,32 \\
Histidina & 1,98 & 1,86 & 2,90 & 2,98 \\
Arginina & 0,49 & 0,24 & 0,36 & 0,40 \\
Triptofano & & & & \\
NÃO ESSENCIAIS & 0,65 & 0,66 & 0,77 & 0,78 \\
Cistina & 0,83 & 0,99 & 1,30 & 1,32 \\
Tirosina & 2,95 & 4,05 & 5,46 & 5,51 \\
Ácido Aspártico & 1,92 & 1,09 & 1,83 & 1,87 \\
Serina & 6,21 & 3,61 & 6,01 & 6,95 \\
Ácido Glutâmico & 2,21 & 2,41 & 2,80 & 2,88 \\
Prolina & 2,33 & 2,63 & 4,41 & 4,30 \\
Glicina & 2,29 & 2,30 & 3,76 & 4,19 \\
Alanina & & & &
\end{tabular}

Vidotti et al. (2002), testando a digestibilidade de silagens ácidas e biológicas preparadas a partir de diferentes matérias-primas, na alimentação do pacu (Piaractus mesopotamicus), utilizando o método de extrusão manual para a coleta de fezes e o 
óxido de cromo como marcador, encontraram valores de $\mathrm{CDA}_{\mathrm{MS}}$ de 71,56 e $74,34 \%$ para $\mathrm{SA}$ e $\mathrm{SB}$, respectivamente, valores menores dos que os obtidos nesta pesquisa para as SA e SB.

Tabela 4. Coeficientes de digestibilidade aparente da energia e nutrientes da ração referência e das silagens biológica, ácida e enzimática.

\begin{tabular}{lcccccc}
\hline & $\begin{array}{c}\text { Ração } \\
\text { referência } \\
(\%)\end{array}$ & $\begin{array}{c}\text { Silagem } \\
\text { biológica } \\
(\%)\end{array}$ & $\begin{array}{c}\text { Silagem } \\
\text { ácida } \\
(\%)\end{array}$ & $\begin{array}{c}\text { Silagem } \\
\text { enzimática }\end{array}$ & $\begin{array}{c}\text { Erro } \\
\text { Padrão }\end{array}$ & $\begin{array}{c}\text { ANOVA } \\
\text { Pr>F }\end{array}$ \\
\hline Matéria seca & $85,07^{\mathrm{a}} \pm 1,74$ & $78,98^{\mathrm{c}} \pm 2,05$ & $82,52^{\mathrm{b}} \pm 0,77$ & $82,96^{\mathrm{ab}} \pm 0,46$ & 0,9099 & 0,0001 \\
Proteína & $96,67^{\mathrm{a}} \pm 0,36$ & $89,09^{\mathrm{d}} \pm 1,43$ & $92,01^{\mathrm{c}} \pm 0,54$ & $93,66^{\mathrm{b}} \pm 0,19$ & 0,3965 & 0,0001 \\
Cinza & $81,64^{\mathrm{b}} \pm 1,01$ & $87,61^{\mathrm{a}} \pm 1,27$ & $89,86^{\mathrm{a}} \pm 1,20$ & $90,10^{\mathrm{a}} \pm 2,27$ & 0,6948 & 0,0001 \\
Energia & $85,06^{\mathrm{b}} \pm 1,20$ & $84,53^{\mathrm{b}} \pm 1,15$ & $86,39^{\mathrm{b}} \pm 1,75$ & $89,09^{\mathrm{a}} \pm 0,36$ & 1,2003 & 0,0002 \\
Fósforo & $87,98^{\mathrm{a}} \pm 1,35$ & $79,21^{\mathrm{bc}} \pm 1,16$ & $77,86^{\mathrm{c}} \pm 1,56$ & $81,46^{\mathrm{b}} \pm 0,81$ & 0,8260 & 0,0001 \\
Cálcio & $86,12^{\mathrm{a}} \pm 1,10$ & $73,99^{\mathrm{c}} \pm 0,65$ & $81,72^{\mathrm{b}} \pm 0,61$ & $80,27^{\mathrm{b}} \pm 0,41$ & 0,5014 & 0,0001 \\
\hline
\end{tabular}

Nota: média de cinco repetições \pm erro padrão; letras iguais não diferem significativamente a $\mathrm{P}<0,01$.

$\mathrm{O} \mathrm{CDA}_{\mathrm{MS}}$ da SB foi semelhante ao obtido por Fagbenro \& Bello-Olusoji (1997), que obtiveram valores de 77,30 e 79,50\%, com a SB elaborada com cabeças de camarão adicionadas de farelo de soja ou farinha de penas hidrolisadas, respectivamente, na alimentação do bagre africano (Clarias gariepinus).

Estudando diferentes aglutinantes em dietas úmidas para a tilápia contendo $50 \%$ de SB, produzidas a partir de tilápias inteiras, Fagbenro \& Jauncey (1995a), com exceção da dieta que continha o goma guar, cujo $\mathrm{CDA}_{\mathrm{MS}}$ foi de $73,40 \%$, encontraram valores de $\mathrm{CDA}_{\mathrm{MS}}$ entre 82,80 e $84,30 \%$, resultados semelhantes aos obtidos na nesta pesquisa para SA e SE.

Fagbenro \& Jauncey (1998) estudaram a utilização de dietas úmidas para a tilápia do Nilo, usando a SB de tilápias (SBT) misturada com diferentes ingredientes protéicos (farinha de peixe (FP); farinha de penas hidrolisadas/farelo de soja (FPH/FS) 
ou farinha de subprodutos avícolas (FSAv)). Estes autores obtiveram valores de $\mathrm{CDA}_{\mathrm{MS}}$ de 85,90, 82,40 e 84,70\% para as dietas contendo SBT+FP, SBT+FPH/FS e SBT+FSAv, respectivamente. Estes valores foram superiores aos encontrados nesta pesquisa, com exceção da dieta $\mathrm{SBT}+\mathrm{FPH} / \mathrm{FS}$, que foi próximo ao $\mathrm{CDA}_{\mathrm{MS}}$ obtido pela $\mathrm{SA}$ e $\mathrm{SE}$.

Conforme pode ser observado na Tabela 4, todos os ingredientes testados resultaram em valores elevados para os CDA da proteína bruta e energia bruta.

Os resultados obtidos para o $\mathrm{CDA}_{\mathrm{PB}}$ nesta pesquisa, foram inferiores aos encontrados por Goddard \& Al-Yahyai (2001), com a SA para a tilápia do Nilo e Stone et al. (1989) também com a SA, para a truta arco-íris (Onchorynchus mykiss), que obtiveram valores de $\mathrm{CDA}_{\mathrm{PB}}$ de 95,10 e 94,00\%, respectivamente.

Por outro lado, os $\mathrm{CDA}_{\mathrm{PB}}$ encontrados nesta pesquisa foram superiores aos obtidos por Vidotti et al. (2002), na alimentação do pacu com a SA e SB (74,71 e $83,43 \%$, respectivamente) e por Hardy et al. (1984) com SA utilizada na alimentação da truta arco-íris $(80,10 \%)$.

Stone \& Hardy (1986), testando a digestibilidade da SA na alimentação da truta arco-íris, utlizando o método de extrusão manual para coleta de fezes, encontraram o valor de $88,70 \%$ para o $\mathrm{CDA}_{\mathrm{PB}}$, próximo ao encontrado para o $\mathrm{CDA}_{\mathrm{PB}}$ da $\mathrm{SB}$ na nossa pesquisa.

Fagbenro \& Bello-Olusoji (1997), encontraram valores de CDA $\mathrm{PB}_{\text {de }}$ 90,80\%, próximos aos obtidos neste trabalho para a SA e SB, quando utilizaram uma dieta contendo SB adicionada de farelo de soja na proporção de 1:1, para a alimentação do bagre africano. Para a coleta de fezes os autores utilizaram o método de dessecação e como marcador o óxido de cromo.

As diferenças entre os resultados obtidos pela nossa pesquisa e as demais, podem estar relacionadas com a qualidade da matéria-prima, processamento, quantidade de cinza, lipídeos, tempo de estocagem, entre outros. (Allan et al., 2000; Anderson et al., 1992; Lee, 2002, NRC, 1993). De acordo com o NRC (1993), as proteínas provenientes de tecidos conectivos e ossos são menos digeridas que as do músculo.

Os altos $\mathrm{CDA}_{\mathrm{PB}}$ e $\mathrm{CDA}_{\mathrm{EB}}$ confirmam a habilidade da tilápia do Nilo em digerir a proteína de fontes de origem animal, corroborando os resultados obtidos por Hanley 
(1987) e Masumoto et al. (1996). O CDA $\mathrm{EB}_{\text {, }}$ apresentado nesta pesquisa para a SE, ficou próximo ao apresentado por Goddad \& Al-Yahyai (2001) para a silagem ácida $(89,80 \%$ $\pm 0,94)$.

Os $\mathrm{CDA}_{\mathrm{EB}}$ da $\mathrm{SA}$ e $\mathrm{SB}$ ficaram próximos aos encontrados por Fagbenro (1994), para a SB na alimentação da tilápia do Nilo, Fagbenro \& Jauncey (1995b, 1998) com a tilápia do Nilo e bagre africano, respectivamente e Fagbenro \& Bello-Olusoji (1997) com o bagre africano. Fagbenro \& Bello-Olusoji (1997) encontraram valores de $\mathrm{CDA}_{\mathrm{EB}}$ de 84,90 e $86,40 \%$ para a SB misturadas com farelo de soja e subprodutos de aves, respectivamente.

Nossos resultados de $\mathrm{CDA}_{\mathrm{MS}} \mathrm{CDA}_{\mathrm{EB}}$, concordam com o relatado por Allan et al. (2000) e Lee (2002) onde, de maneira geral, ingredientes que possuem bons $\mathrm{CDA}_{\mathrm{MS}}$, terão também bons $\mathrm{CDA}_{\mathrm{EB}}$. Estes obtidos para o $\mathrm{CDA}_{\mathrm{EB}}$, podem ser explicados pela característica do óleo da silagem de pescado ser insaturado, sendo melhor absorvido que ingredientes que possuem maiores quantidades de lipídeos saturados, conforme observado por Allan et al. (2000) em farinhas de diferentes origens.

Furuya (2000) encontrou valores de $\mathrm{CDA}_{\mathrm{Ca}}$ de $86,30 \%$ e $\mathrm{CDA}_{\mathrm{P}}$ de $76,67 \%$, ao utilizar dieta purificada na alimentação da tilápia do Nilo. O $\mathrm{CDA}_{\mathrm{Ca}}$ ficou próximo ao obtido nessa pesquisa, utilizando a mesma dieta referência (purificada). Já o CDAP encontrado pelo autor foi inferior ao obtido nesta pesquisa com a mesma espécie.

Os valores encontrados neste trabalho para os três tipos de silagens, foram maiores do que o $\mathrm{CDA}_{\mathrm{Ca}}$ e CDA $\mathrm{CD}_{\mathrm{P}}$ apresentados por Portz (2001), de 62,81\% e 72,28\%, respectivamente, para a farinha de peixe na alimentação do "black bass" (Micropterus salmoides), utilizando o método de sedimentação para coleta de fezes e o óxido de cromo como marcador. Este mesmo autor testando a digestibilidade da farinha de vísceras, encontrou valores de $86,67 \%$ para o $\mathrm{CDA}_{\mathrm{Ca}}$ e de $93,93 \%$ para o $\mathrm{CDA}_{\mathrm{P}}$, sendo superiores aos obtidos pela SA, SB e SE.

Furuya et al. (2001) encontraram valores de $\mathrm{CDA}_{\mathrm{Ca}}$ de 90,62\% e 85,04\% e $\mathrm{CDA}_{P}$ de $49,78 \%$ e 47,14\% para a farinha de peixe e farelo de soja, respectivamente. Os valores de $\mathrm{CDA}_{\mathrm{Ca}}$ obtidos por estes autores foram superiores aos encontrados nesta 
pesquisa para as silagens testadas, porém os $\mathrm{CDA}_{P}$ das silagens foram superiores aos da farinha de peixe e farelo de soja.

A boa disponibilidade de cálcio e fósforo apresentada pelas silagens, pode estar relacionada com seu pH ácido, conforme demonstrado por Sugiura et al. (1998), que observaram melhor disponibilidade dos minerais da farinha de peixe quando adicionada de $5 \%$ de ácido cítrico.

Os resultados dos CDA dos aminoácidos das silagens e da RR estão apresentados na Tabela 5. Com exceção do CDA do triptofano, fenilalanina e ácido aspártico, todos os demais CDA dos aminoácidos apresentaram diferenças entre si $(\mathrm{P}<0,05)$.

Os valores médios do CDAaa foram de 90,76, 91,83 e 94,61\% para a SB, SA e SE, respectivamente. Como pode ser observado, os ingredientes testados, apresentaram valores elevados de CDAaa.

Neste estudo, entre os aminoácidos essenciais, o triptofano apresentou o maior CDA. Estes resultados contrapõem-se aos apresentados por Fagbenro \& Bello-Olusoji (1997), com a silagem para o bagre africano e Portz (2001) com o farelo de soja e farinha de peixe para o "black bass", nos quais o triptofano apresentou o menor CDA.

Por outro lado, nossos resultados concordam com os obtidos por Anderson et al. (1992) com o farelo de soja e farinha de peixe e Anderson et al. (1995) com a farinha de arenque e farinha de anchovas, ambos trabalhando com o salmão do Atlântico (Salmo salar).

Ainda entre os AAE, a arginina apresentou o menor valor de CDA. Estes resultados concordam com Hossain \& Jauncey (1989), para a farinha de peixe na alimentação da carpa comum (Cyprinus carpio). Porém, contrapõem-se aos apresentados por Furuya (2000), que testou ingredientes de origem animal e vegetal para a tilápia do Nilo e Anderson et al. (1992), para o farelo de canola, com o salmão do Atlântico.

Entre os AANE, o maior CDA foi o apresentado pela tirosina, concordando com os resultados obtidos por Portz (2001) para as farinhas de peixe e de vísceras com o "black bass". O menor CDA entre os AANE foi obtido pela glicina, este resultado concorda com Hossain \& Jauncey (1989) para a farinha de peixe, Anderson et al. (1992) 
para a farinha de peixe e farelo de soja e Allan et al. (2000) para a farinha de carne e OSSOS.

Tabela 5. Coeficientes de digestibilidade aparente dos aminoácidos essenciais e não essenciais da ração referência e das silagens biológica, ácida e enzimática.

\begin{tabular}{|c|c|c|c|c|c|c|}
\hline Aminoácidos & $\begin{array}{c}\text { Ração } \\
\text { referência }\end{array}$ & $\begin{array}{l}\text { Silagem } \\
\text { biológica }\end{array}$ & $\begin{array}{l}\text { Silagem } \\
\text { ácida }\end{array}$ & $\begin{array}{c}\text { Silagem } \\
\text { enzimática }\end{array}$ & $\begin{array}{c}\text { Erro } \\
\text { Padrão }\end{array}$ & $\begin{array}{c}\text { ANOVA } \\
\operatorname{Pr}>\mathrm{F}\end{array}$ \\
\hline \multicolumn{7}{|l|}{ ESSENCIAIS } \\
\hline Valina & $97,18^{\mathrm{a}} \pm 0,25$ & $88,99^{\mathrm{b}} \pm 2,54$ & $92,78^{\mathrm{ab}} \pm 1,01$ & $97,25^{\mathrm{a}} \pm 0,52$ & 2,2272 & 0,0035 \\
\hline Metionina & $96,98^{\mathrm{ab}} \pm 0,26$ & $96,04^{\mathrm{ab}} \pm 1,04$ & $94,84^{a} \pm 0,84$ & $98,25^{\mathrm{b}} \pm 2,01$ & 0,9122 & 0,0305 \\
\hline Isoleucina & $96,15^{\mathrm{ab}} \pm 0,90$ & $89,26^{\mathrm{b}} \pm 1,82$ & $97,17^{\mathrm{a}} \pm 2,30$ & $96,33^{\mathrm{ab}} \pm 1,97$ & 3,4484 & 0,0158 \\
\hline Leucina & $96,34^{\mathrm{a}} \pm 1,07$ & $91,52^{\mathrm{b}} \pm 1,11$ & $91,24^{\mathrm{b}} \pm 1,00$ & $95,60^{\mathrm{ab}} \pm 1,36$ & 1,2795 & 0,0057 \\
\hline Treonina & $95,07^{\mathrm{ab}} \pm 1,17$ & $94,33^{\mathrm{ab}} \pm 1,39$ & $91,71^{\mathrm{b}} \pm 0,71$ & $96,94^{\mathrm{a}} \pm 1,58$ & 1,5076 & 0,0227 \\
\hline Fenilalanina & $96,73^{\mathrm{a}} \pm 0,72$ & $90,97^{\mathrm{a}} \pm 2,92$ & $92,96^{\mathrm{a}} \pm 2,25$ & $95,98^{\mathrm{a}} \pm 1,29$ & 3,6513 & 0,0667 \\
\hline Lisina & $97,16^{\mathrm{a}} \pm 0,92$ & $94,37^{\mathrm{b}} \pm 0,37$ & $94,75^{\mathrm{ab}} \pm 0,57$ & $97,09^{\mathrm{a}} \pm 0,84$ & 0,4019 & 0,0062 \\
\hline Histidina & $97,58^{\mathrm{a}} \pm 0,58$ & $94,88^{\mathrm{b}} \pm 0,63$ & $96,17^{\mathrm{ab}} \pm 0,29$ & $97,39^{\mathrm{a}} \pm 0,92$ & 0,2785 & 0,0046 \\
\hline Arginina & $98,23^{\mathrm{a}} \pm 0,55$ & $88,90^{\mathrm{b}} \pm 1,73$ & $89,46^{\mathrm{b}} \pm 0,52$ & $93,33^{\mathrm{b}} \pm 0,58$ & 1,2801 & 0,0005 \\
\hline Triptofano & $97,92^{\mathrm{a}} \pm 0,86$ & $96,97^{\mathrm{a}} \pm 0,96$ & $97,88^{\mathrm{a}} \pm 0,88$ & $97,66^{\mathrm{a}} \pm 0,76$ & 0,3227 & 0,0939 \\
\hline \multicolumn{7}{|l|}{ NÃO } \\
\hline \multicolumn{7}{|l|}{ ESSENCIAIS } \\
\hline Cistina & $97,14^{\mathrm{a}} \pm 1,77$ & $93,72^{\mathrm{ab}} \pm 0,70$ & $92,06^{\mathrm{b}} \pm 0,77$ & $97,20^{\mathrm{a}} \pm 1,34$ & 1,7344 & 0,0167 \\
\hline Tirosina & $95,07^{\mathrm{b}} \pm 0,65$ & $94,67^{\mathrm{b}} \pm 1,65$ & $95,82^{\mathrm{ab}} \pm 0,70$ & $97,28^{\mathrm{a}} \pm 1,02$ & 0,0277 & 0,0036 \\
\hline Ácido Aspártico & $96,95^{\mathrm{a}} \pm 1,11$ & $93,84^{\mathrm{a}} \pm 1,25$ & $94,39^{\mathrm{a}} \pm 1,59$ & $95,73^{\mathrm{a}} \pm 2,47$ & 3,3335 & 0,3962 \\
\hline Serina & $96,52^{\mathrm{a}} \pm 2,28$ & $86,77^{\mathrm{b}} \pm 2,64$ & $90,42^{\mathrm{ab}} \pm 1,78$ & $90,68^{\mathrm{ab}} \pm 1,94$ & 5,2749 & 0,0258 \\
\hline Ácido Glutâmico & $97,84^{\mathrm{a}} \pm 1,48$ & $88,62^{\mathrm{b}} \pm 2,35$ & $89,46^{\mathrm{ab}} \pm 1,53$ & $93,45^{\mathrm{ab}} \pm 2,10$ & 4,5161 & 0,0164 \\
\hline Prolina & $97,62^{\mathrm{a}} \pm 0,64$ & $83,76^{\mathrm{b}} \pm 1,98$ & $84,51^{\mathrm{b}} \pm 1,84$ & $87,02^{\mathrm{b}} \pm 0,90$ & 2,2694 & 0,0003 \\
\hline Glicina & $96,69^{\mathrm{a}} \pm 1,43$ & $80,90^{\mathrm{b}} \pm 1,44$ & $80,96^{\mathrm{b}} \pm 1,74$ & $82,76^{b} \pm 1,39$ & 3,1116 & 0,0002 \\
\hline Alanina & $97,01^{\mathrm{a}} \pm 0,75$ & $85,14^{\mathrm{b}} \pm 2,98$ & $86,34^{b} \pm 2,75$ & $92,97^{\mathrm{ab}} \pm 1,74$ & 5,2045 & 0,0055 \\
\hline
\end{tabular}

Nota: média de três repetições \pm erro padrão; letras iguais não diferem significativamente a $\mathrm{P}<0,05$. 
No geral, o menor CDA dos nutrientes e aminoácidos da SB pode estar relacionado com a quantidade de melaço adicionada, pois durante o período de coleta de fezes, observou-se maior quantidade de fezes produzidas pelos peixes tratados com este ingrediente, além de coloração levemente "amarronzada" nos aquários de coleta de fezes e alimentação. Apesar da tilápia do Nilo utilizar eficientemente altos níveis de carboidratos (Tengjaroenkul et al., 2000), seu excesso pode afetar, negativamente, a digestibilidade de certos nutrientes (Storebakken et al., 1998).

Os CDAaa médios da SB, SA e SE, apresentados neste estudo, foram superiores aos encontrados por Furuya (2000) para a farinha de peixe, com a tilápia do Nilo e Portz (2001) também para a farinha de peixe, com o "black bass"e, inferiores, aos obtidos pelos mesmos autores quando trabalharam com o farelo de soja. A diferença na utilização dos aminoácidos de farinhas, produzidas a partir de diferentes origens, foi relatada por Allan et al. (2000), trabalhando com a perca prateada (Bydianus bydianus).

As diferenças nos resultados do CDA dos nutrientes, energia bruta e aminoácidos, podem estar relacionadas com a espécie utilizada e, portanto, com a habilidade desta em utilizar determinados nutrientes, metodologia de coleta de fezes, tipo de ração referência, marcador utilizado, composição química dos ingredientes e processamento a que esses ingredientes foram submetidos.

Os valores médios do $\mathrm{CDA}_{\mathrm{PB}}$ e CDAaa dos ingredientes analisados, foram bastante semelhantes, concordando com Portz (2001), Sales \& Britz (2003) e Hossain \& Jauncey (1989). Por outro lado, contrapõem-se aos apresentados por Anderson et al. (1992), que não encontraram valores próximos de CDA $\mathrm{PB}_{\mathrm{BB}}$ e CDAaa trabalhando com o salmão do Atlântico.

Mesmo existindo relação entre os valores médios do $\mathrm{CDA}_{\mathrm{PB}}$ e CDAaa, a determinação da digestibilidade individual dos aminoácidos é muito importante para a formulação de dietas completas e que proporcionem máximo desempenho, de forma a evitar a deficiência ou excesso de um determinado aminoácido, pois o CDA pode ser bastante variável para alguns aminoácidos (Anderson et al. 1992; Anderson et al., 1995; Furuya, 2000; Lee, 2002; Sales \& Britz, 2003; Stone et al., 2000). 
Na Tabela 6 encontram-se os valores de aminoácidos digestíveis em g/100g de matéria seca. Na Tabela 7 podemos comparar os valores dos AAE das silagens, em g de aminoácidos digestíveis/100g de proteína digestível, com as exigências em AAE da tilápia do Nilo, estabelecidos pelo NRC (1993).

Tabela 6. Valores de proteína e aminoácidos essenciais e não essenciais digestíveis da ração referência e das silagens biológica, ácida e enzimática $(\mathrm{g} / 100 \mathrm{~g}$ de matéria seca).

\begin{tabular}{lcccc}
\hline Aminoácidos & $\begin{array}{c}\text { Ração } \\
\text { referência }\end{array}$ & $\begin{array}{c}\text { Silagem } \\
\text { biológica }\end{array}$ & $\begin{array}{c}\text { Silagem } \\
\text { ácida }\end{array}$ & $\begin{array}{c}\text { Silagem } \\
\text { enzimática }\end{array}$ \\
\hline ESSENCIAIS & $1,82^{1}$ & 1,26 & 2,51 & 2,90 \\
Valina & 1,51 & 1,79 & 2,06 & 2,17 \\
Metionina & 1,61 & 1,07 & 3,14 & 2,13 \\
Isoleucina & 2,50 & 2,21 & 3,19 & 3,16 \\
Leucina & 1,12 & 1,55 & 1,87 & 2,04 \\
Treonina & 1,51 & 1,19 & 1,91 & 2,12 \\
Fenilalanina & 2,13 & 2,27 & 3,16 & 3,13 \\
Lisina & 0,66 & 0,94 & 1,35 & 1,29 \\
Histidina & 1,94 & 1,65 & 2,59 & 2,78 \\
Arginina & 0,48 & 0,23 & 0,35 & 0,39 \\
Triptofano & & & & \\
NÃO ESSENCIAIS & 0,63 & 0,62 & 0,71 & 0,76 \\
Cistina & 0,79 & 0,94 & 1,25 & 1,28 \\
Tírosina & 2,86 & 3,80 & 5,15 & 5,27 \\
Ácido Aspártico & 1,85 & 0,95 & 1,65 & 1,70 \\
Serina & 6,08 & 3,20 & 5,38 & 6,49 \\
Ácido Glutâmico & 2,16 & 2,02 & 2,37 & 2,51 \\
Prolina & 2,25 & 2,13 & 3,57 & 3,56 \\
Glicina & 2,22 & 1,96 & 3,25 & 3,90 \\
Alanina & 36,44 & 29,40 & 49,92 & 51,04 \\
Proteína digestível & & & & \\
\hline
\end{tabular}

${ }^{1}$ Valores calculados com base nas tabelas 3 e 5 .

${ }^{2}$ Valores calculados com base nas tabelas 2 e 4. 
Com base na Tabela 7 pode-se observar que os três tipos de silagens têm como aminoácido limitante o triptofano

Os resultados encontrados não comprometem o valor nutricional das silagens, já que estas seriam apenas um dos ingredientes a fazer parte de uma dieta balanceada.

A parcial desidratação da silagem ("co-secagem”) através da adição de outros produtos ou subprodutos é uma ferramenta que vem sendo utilizada, com sucesso, por diversos autores (Fagbenro, 1994, Fagbenro et al., 1995a; Fagbenro \& Bello-Olusoji, 1997, Vidotti, 2001). A mistura da silagem de pescado com o farelo de soja vem obtendo melhores resultados em experimentos de desempenho e digestibilidade com diversas espécies de peixes.

Tabela 7. Valores de aminoácidos essenciais (g de aminoácido digestível/100g de proteína digestível) das silagens e valores das exigências em aminoácidos essenciais pela tilápia do Nilo, segundo NRC (1993) (g de aminoácido/100g de proteína).

\begin{tabular}{lcccc}
\hline Aminoácidos & $\begin{array}{c}\text { Silagem } \\
\text { biológica }\end{array}$ & $\begin{array}{c}\text { Silagem } \\
\text { ácida }\end{array}$ & $\begin{array}{c}\text { Silagem } \\
\text { enzimática }\end{array}$ & $\begin{array}{c}\text { NRC } \\
(1993)\end{array}$ \\
\hline ESSENCIAIS & & & & \\
Valina & 4,29 & 5,03 & 5,68 & 2,80 \\
Metionina + Cistina & 8,20 & 5,55 & 5,74 & 2,68 \\
Isoleucina & 3,64 & 6,29 & 4,17 & 3,11 \\
Leucina & 7,52 & 6,39 & 6,19 & 3,39 \\
Treonina & 5,27 & 3,75 & 4,00 & 3,75 \\
Fenilalanina + Tirosina & 7,24 & 6,33 & 6,66 & 3,75 \\
Lisina & 7,72 & 6,33 & 6,13 & 5,12 \\
Histidina & 3,20 & 2,70 & 2,53 & 1,72 \\
Arginina & 5,61 & 5,19 & 5,45 & 4,20 \\
Triptofano & 0,78 & 0,70 & 0,76 & 1,00 \\
\hline
\end{tabular}

A "co-secagem" da silagem ajuda a diminuir o teor de umidade e melhorar as possíveis limitações no perfil de aminoácidos. Por exemplo, Portz (2001) encontrou para o farelo de soja um valor de $1,30 \mathrm{~g}$ de triptofano digestível/100g de proteína digestível, 
valor acima da exigência da tilápia do Nilo para este aminoácido, estabelecido pelo NRC (1993), portanto, a mistura deste ingrediente com a silagem de pescado melhoraria o perfil de aminoácidos e, conseqüentemente, o valor nutricional do produto final.

\subsection{Conclusões}

Pelos resultados do presente estudo podemos concluir que a SA, SB e SE, foram eficientemente utilizadas pela tilápia do Nilo, apresentando altos valores de CDA dos nutrientes, energia bruta e aminoácidos podendo, portanto, ser utilizadas como substitutos parciais da farinha de pescado em rações para peixes.

A limitação das silagens com relação ao triptofano, não é preocupante já que a silagem é apenas um dos ingredientes que farão parte de uma dieta balanceada. A mistura da silagem com outro produto, como o farelo de soja, por exemplo, também seria uma forma de melhorar essa limitação.

Em adição, ressalta-se a importância do conhecimento do CDA para avaliar, adequadamente, o potencial da utilização de fontes protéicas alternativas em dietas completas que permitam máximo desempenho, mínimo custo e minimizem os problemas de poluição em decorrência de nutrientes não aproveitados.

As silagens enzimática e ácida, de maneira geral, apresentaram melhores resultados que a silagem biológica. Como a elaboração da silagem ácida é mais simples que as demais, e os resultados obtidos demonstram que ela pode ser utilizada eficientemente em rações para a tilápia do Nilo (Oreochromis niloticus), recomenda-se a utilização desta em dietas para peixes.

\subsection{Referências bibliográficas}

ALLAN, G.L; PARKINSON, S.; BOOTH, M.A. et al. Replacement of fish meal in diets for Australian silver perch, Bidyanus bidyanus: I digestibility of alternative ingredients. Aquaculture, v.186, p.293-310, 2000. 
ANDERSON, J.S.; LALL, S.P.; ANDERSON, D.M.; CHANDRASOMA, J. Apparent and true availability of amino acids from common feed ingredients for Atlantic salmon (Salmo salar) reared in sea water. Aquaculture, v.108, p.111-114, 1992.

ANDERSON, J.S.; LALL, S.P.; ANDERSON, D.M.; MCNIVEN, M.A. Availability of amino acids from various fish meals fed to Atlantic salmon (Salmo salar). Aquaculture, v.138, p.291-301, 1995.

ASSOCIATION OF OFFICIAL ANALYTICAL CHEMISTS. Official methods of analysis. 14.ed. Washington, 1984. 1141p.

BERGE, G.M.; STOREBAKKEN, Y. Fish protein hydrolyzate in starters diets for Atlantic salmon (Salmo salar) fry. Aquaculture, v.145, p.205-212, 1996.

BRASIL. Ministério da Agricultura e Abastecimento. Departamento de Fiscalização e Fomento Animal. Compêndio brasileiro de alimentação animal. Brasília, 1998. $120 \mathrm{p}$.

CASTAGNOLLI, N. Piscicultura intensiva e sustentável de espécies nativas brasileiras. In: SIMPÓSIO SOBRE MANEJO E NUTRIÇÃO DE PEIXES. Piracicaba, 1997. Anais. Campinas: CBNA, 1997. p.117-130.

CHENG, Z.J.; HARDY, R.W.; USRY, J.L. Effects of lysine supplementation in plant protein-based diets on the performance of rainbow trout (Oncorhynchus mykiss) and apparent digestibility coefficients of nutrients. Aquaculture, v.215, p.255-265, 2003.

EL-SAYED, A.F.M. Alternative dietary protein sources for farmed tilapia, Oreochromis spp. Aquaculture, v.179, p.149-168, 1999. 
ESPE, M.; LIED, E. Fish silage prepared from different cooked and uncooked raw materials: chemical changes during storage at different temperatures. Journal of the Science of Food and Agriculture, v.79, p.327-332, 1999.

ESPE, M.; RAA, J.; NJAA, L.R. Nutritional value of stored fish silage as a protein source for young rats. Journal of the Science of Food and Agriculture, v.49, p.259-270, 1989.

ESPE, M.; SVEIER, H.; HOGOY, I.; LIED, E. Nutrient absorption and growth of Atlantic salmon (Salmo salar L.) fed fish protein concentrate. Aquaculture, v.174, p.119-137, 1999.

ESPÍNDOLA FILHO, A. Aproveitamento de resíduos sólidos de pescado como fertilizante marinho. São Paulo, 1997. 98p. Dissertação (Mestrado) - Universidade Machenzie.

FAGBENRO, O. Dried fermented fish silage in diets for Oreochromis niloticus. The Israeli Journal of Aquaculture, v.46, n.3, p.140-147, 1994.

FAGBENRO, O.; FASAKIN, E.A. Citric-acid-ensiled poultry viscera as protein supplement for catfish (Clarias gariepinus). Bioresource Technology, v.58, p.13$16,1996$.

FAGBENRO, O.; JAUNCEY, K. Water stability, nutrient leaching and nutritional properties of moist fermented fish silage diets. Aquacultural Engineering, v.14, p.143-153, 1995a.

FAGBENRO, O.; JAUNCEY, K. Growth and protein utilization by juvenile catfish (Clarias gariepinus) feed dry diets containing co-dried lactic-acid-fermented fishsilage and protein feedstuffs. Bioresource Technology, v.51, p.59-35, 1995b. 
FAGBENRO, O.; JAUNCEY, K. Physical and nutritional properties of moist fermented fish silage pellets as a protein supplement for tilapia (Oreochromis niloticus). Animal Feed Science and Technology, v.71, p.11-18, 1998.

FAGBENRO, O.; BELLO-OLUSOJI, O.A. Preparation, nutrient composition and digestibility of fermented shrimp head silage. Food Chemistry, v.60, p.489-493, 1997.

FONTAÍNHAS-FERNANDES， A.; GOMES， E.; REIS-HENRIQUES， M.A.; COIMBRA, J. Replacement of fish meal by plant proteins in the diet of Nile tilapia: digestibility and growth performance. Aquaculture International, v.7, p.57-67, 1999.

FURUYA, W.M. Alimentos ambientalmente corretos para piscicultura. In: REUNIÃO ANUAL DA SOCIEDADE BRASILEIRA DE ZOOTECNIA, 38., Piracicaba, 2001. A produção animal na visão dos brasileiros. Piracicaba: FEALQ, 2001. p.515527.

FURUYA, W.M. Digestibilidade aparente de aminoácidos e substituição da proteína da farinha de peixe pela do farelo de soja com base em proteína ideal em rações para a tilápia do Nilo (Oreochromis niloticus). Botucatu, 2000. 69p. Tese (Doutorado) Faculdade de Medicina Veterinária e Zootecnia, Universidade Estadual Paulista "Júlio de Mesquita Filho".

FURUYA, W.M.; PEZZATO, L.E.; MIRANDA, E.C. et al. Coeficiente de digestibilidade aparente da energia e nutrientes de alguns ingredientes pela tilápia do Nilo (Oreochromis niloticus). In: REUNIÃO ANUAL DA SOCIEDADE BRASILEIRA DE ZOOTECNIA, 38, Piracicaba, 2001. Anais. Piracicaba: FEALQ, 2001. p.1407-1408. 
GIUliETTI, N.; TEIXEIRA FILHO, A.R.; CARVAlHO FILHO, A.C. et al. Repensando a agricultura paulista: cadeia produtiva do pescado. São Paulo: Secretaria da Agricultura e Abastecimento, 1996. 57p.

GODDARD, J.S.; AL-YAHYAI, D.S.S. Chemical and nutritional characteristics of dried sardine silage. Journal of Aquatic Food Product Technology, v.10, n.4, p.39-50, 2001.

GODDARD, J.S.; MCLEAN, E. Acid-insoluble ash as an inert reference material for digestibility studies in tilapia, Oreochromis aureus. Aquaculture, v.194, p.93-98, 2001.

HANLEY, F. The digestibility of foodstuffs in the effects of feeding selectivity on digestibility determination in tilapia, Oreochromis niloticus (L.). Aquaculture, v.66, p.163-179, 1987.

HARDY, R.W.; SHEARER, K.D.; SPINELLI, J. The nutritional properties of co-dried fish silage in rainbow trout (Salmo gairdinieri) dry diets. Aquaculture, v.38, p.3544, 1984.

HONCZARYK, A.; MAEDA, L.S. Crescimento do pirarucu, Arapaima gigas, utilizando dieta à base de ensilado biológico de pescado. In: SIMPÓSIO BRASILEIRO DE AQÜICULTURA, 10., Recife, 1998. Anais. Recife: Persona, 1998. v.2, p.93-100.

HOSSAIN, M.A.; JAUNCEY, K. Studies on the protein, energy and amino acids digestibility of fish meal, mustard oilcake, linseed and sesame meal for common carp (Cyprinus carpio L.). Aquaculture, v.83, p.59-72, 1989. 
LEE, S.M. Apparent digestibility coefficients of various feed ingredients for juvenile and grower rockfish (Sebastes schlegeli). Aquaculture, v.207, p.79-95, 2002.

MASUMOTO, T; RUCHIMAT, T.; ITO, Y. et al. Amino acid availability values for several protein sources for yellowtail (Seriola quinqueradiata). Aquaculture, v.146, p.109-119, 1996.

MOORE, I.; STEIN, W.H. Chromatographic determination of amino acids by use of automatic recording equipments. Methods in Enzymology, v.6, p.919-931, 1963.

MORALES-ULLOA, D.F.; OETTERER, M. Bioconversão de resíduos da indústria pesqueira. Ciência e Tecnologia de Alimentos, v.15, n.3, p.206-214, 1995.

NOGUEIRA JUNIOR, S.; NEGRI NETO, A.; TSUNECHIRO, A. et al. Alimentação animal: realidade e perspectivas. São Paulo: Secretaria da Agricultura e Abastecimento, 1997. 95p. (Coleção cadeias de produção da aqüicultura)

NATIONAL RESEARCH COUNCIL. Nutrient requirements of fish. Washington: National Academy Press, 1993. 115p.

PARÍN, M.A.; ZUGARRAMURDI, A. Aspectos económicos del procesamiento y uso de ensilado de pescado. http://www.fao.org/waicent/faoinfo/agricult/aga/cap4.htm. 1994. 16p. (25 fev. 2003)

PEZZATO, L.E. Alimentos convencionais e não convencionais disponíveis para a indústria da nutrição de peixes e crustáceos. In: SIMPÓSIO INTERNACIONAL SOBRE NUTRIÇÃO DE PEIXES E CRUSTÁCEOS, 1., Campos do Jordão, 1995. Anais. Campinas: CBNA, 1995. p.34-52. 
PORTZ, L. Utilização de diferentes fontes protéicas em dietas formuladas pelo conceito de proteína ideal para o "black bass" (Micropterus salmoides). Piracicaba, 2001. 111p. Tese (Doutorado) - Escola Superior de Agricultura "Luiz de Queiroz", Universidade de São Paulo.

SALES, J.; BRITZ, P.J. Apparent and true availability of amino acids from common feed ingredients for South African abalone (Haliotis midae L.). Aquaculture Nutrition, v.9, p.55-64, 2003.

SAS INSTITUTE. SAS user's guide: statistics. 5.ed. Cary, 1985. 365p.

SPIES, J.R. Determination of tryptophan in proteins. Analytical Chemistry, v.39, p.1412-1415, 1967.

STONE, D.A.J.; ALLAN, G.L.; PARKINSON, S.; ROWLAND, S.J. Replacement of fish meal in diets for Australian silver perch, Bidyanus bidyanus. III. Digestibility and growth using meat meal products. Aquaculture, v.186, p.311-326, 2000.

STONE, F.E.; HARDY, R.W. Nutritional value of acid stabilised silage and liquefied fish protein. Journal of the Science of Food and Agriculture, v.37, p.797-803, 1986.

STONE, F.E.; HARDY, R.W.; SHEARER, K.D.; SCOTT, T.M. Utilization of fish silage by rainbow trout (Salmo gairdineri). Aquaculture, v.76, p.109-118, 1989.

STOREBAKKEN, T.; SHEARER, K.D.; ROEM, A.J. Availability of protein, phosphorus and other elements in fish meal, soy protein concentrate and phytatetreated soy protein concentrate based diets to Atlantic salmon, Salmo salar. Aquaculture, v.161, p.365-379, 1998. 
SUGIURA, S.H.; DONG, F.M.; HARDY, R.W. Effect of dietary supplements on the availability of mineral in fish meal: preliminary observation. Aquaculture, v.160, p.283-303, 1998.

TENGJAROENKUL, B.; SMITH, B.J.; CACECI, T; SMITH, S.A. Distribution of intestinal enzyme activities along the intestinal tract of cultured Nile tilapia, Oreochromis niloticus L. Aquaculture, v.182, p.317-327, 2000.

VALENTI, W.C. Aquaculture for sustainable development. In: VALENTI, W.C.; POLI, C.R.; PEREIRA, J.A.; BORGHETTI, J.R. Aqüicultura no Brasil. Brasília: CNPq/Mistério da Ciência e Tecnologia, 2000. p.17-24.

VALÉRIO, A.C.R. Elaboração de silagem enzimática de pescado como alternativa ao processo tradicional. Piracicaba, 1994. 102p. Dissertação (Mestrado) - Escola Superior de Agricultura "Luiz de Queiroz", Universidade de São Paulo.

VIDOTTI, R.M. Produção e utilização de silagens de peixe na nutrição do pacu (Piaractus mesopotamicus). Jaboticabal, 2001. 65p. Tese (Doutorado) - Centro de Aqüicultura, Universidade Estadual Paulista “Júlio de Mesquita Filho”.

VIDOTTI, R.M.; CARNEIRO, D.J; VIEGAS, E.M.M. Acid and fermented silage characterization and determination of apparent digestibility coefficient of crude protein for pacu Piaractus mesopotamicus. Journal of World Aquaculture Society, v.33, n.1, p.57-62, 2002. 


\section{CONCLUSÕES GERAIS}

O sucesso da produtividade na aqüicultura, principalmente a intensiva, depende em grande parte da elaboração e utilização de rações completas. Portanto, faz-se necessário a avaliação das características nutricionais dos ingredientes a serem utilizados na composição destas rações.

A farinha de peixe é a principal fonte protéica utilizada na elaboração de rações para organismos aquáticos. Porém, face à progressiva escassez e elevado custo desse insumo nos mercados mundial e nacional, a produção de rações comerciais completas com qualidade, dependerá da elaboração de um substituto adequado do ponto de vista nutricional e econômico.

Os resultados da composição centesimal e coeficientes de digestibilidade aparente das silagens produzidas nesta pesquisa levam a recomendação do seu uso como ingrediente protéico alternativo em dietas para a tilápia do Nilo (Oreochromis niloticus), considerando-se os seguintes aspectos:

1) Elevados teores de proteína bruta e presença de todos os aminoácidos essenciais, com pequena limitação para o triptofano, com relação às exigências em aminoácidos essenciais para tilápia do Nilo, segundo o NRC (1993), o que não representa um problema já que a silagem entraria como um dos ingredientes da ração. Outra forma de solucionar o problema é a adição de outro produto ou subproduto, desidratando parcialmente a silagem (silagem co-seca), que ajudaria a melhorar o perfil de aminoácidos

e diminuir o teor de umidade da silagem. Uma alternativa é a "cosecagem" com o farelo de soja, na proporção de 1:1;

2) A fração lipídica das silagens apresentou maiores teores de ácidos graxos insaturados, importantes na alimentação dos peixes e na característica do 
filé, já que os lipídeos incorporados nos tecidos dependem do ingerido, ou seja, espelham o conteúdo do alimento consumido;

3) As silagens apresentaram valores elevados dos coeficientes de digestibilidade aparente da proteína e dos aminoácidos, o que permite concluir que a tilápia do Nilo utilizou eficientemente a proteína e os aminoácidos das silagens produzidas nesta pesquisa;

4) De uma forma geral, as silagens ácida e enzimática obtiveram desempenho bastante semelhantes nos dois experimentos. Recomenda-se o uso da silagem ácida pela facilidade de produção e possibilidade de utilização de diferentes combinações de ácidos, com bons resultados conforme descritos na literatura. 


\section{REFERÊNCIAS BIBLIOGRÁFICAS}

ALLAN, G.L; PARKINSON, S.; BOOTH, M.A.; STONE, D.A.J.; ROWLAND, S.J.; FRANCES, J.; WARNES-SMITH, R. Replacement of fish meal in diets for Australian silver perch, Bidyanus bidyanus: I digestibility of alternative ingredients. Aquaculture, v.186, p.293-310, 2000.

Alliot, E.; PASTOREAUDT, A.; PELAEZ HUDLET, J.; MÉTAILlER, R. Utilisation des farines végetales et des levedures cultivées sur alcanes pour l'alimentation du bar (Dicentrarchus labrax). In: WORLD SYMPOSIUM FINFISH NUTRITION FISHFEED TECHNOLOGY, Hambur, 1978. Proceedings. Berlin: Heenemann, 1978. v.2, p.229-238.

ANDRIGUETO, J.M.; PERLY, L.; MINARDI, I.; GEMAEL, A.; FLEMING, J.S.; SOUZA, G.A.; BONA-FILHO, A. Nutrição animal. Curitiba: Nobel, 1982. v.1.

AUSTRENG, E. Digestibility determination in fish using chromic oxide marking and analysis of contents from different segments of gastrointestinal tract. Aquaculture, v.13, p.265-272, 1978.

BATTERHAM, E.S.; GORMAN, T.B.S. Fish silage for growing pigs. In: FARRELL, D.J. Recents advances in animal nutrition. Armidale: University of New England, 1980. p.111-115. 
BERENZ, Z. Utilización del ensilado de residuos de pescado en pollos. http://www.fao.org/waicent/faoinfo/agricult/aga/agap/frg/aph134/cap2.htm. 1994. 11p. (25 fev. 2003)

BORRENSEN, T. Biotechnology, by products and aquaculture. In: BLIGH, E.G. Seafood science and technology. Surrey: Fishing News Books, 1990. p.278-287.

BRASIL. Ministério da Agricultura e do Abastecimento. Setor pesqueiro. http://www.setorpesqueiro.com.br/ministerios/ministerio_da_agricultura_e_do_abas tecimento/dpa/cadeias_produtivas/tilapia/prod_brasileira.shtm (26 fev. 2002)

BUREAU, D.P.; HARRIS, A.M.; CHO, C.Y. Apparent digestibility of rendered animal protein ingredients for rainbow trout (Oncorhynchus mykiss). Aquaculture, v.180, p.345-358, 1999.

CHAMBERS IV, E.; ROBEL, A. Sensory characteristics of selected species of freshwater fish in retail distribution Journal of Food Science, v.58, n.3, p.508-561, 1993.

CHONG, A.S.C.; HASHIM, R.; ALI, A.B. Assesment of dry matter and protein digestibilities of selected raw ingredients by discus fish (Symphysodon aequifasciata) using in vivo and in vitro methods. Aquaculture Nutrition, v.8, p.229-238, 2002.

CHOUBERT, G.; NOUE, J. de la; LUQUET, P. Digestibility in fish: improved device for the automatic collection of feces. Aquaculture, v.29, p.185-189, 1982.

COELLO, N.; BRITO, L.; NONUS, M. Biosynthesis of L-lysine by Corynebacterium glutamicum grown on fish silage. Bioresource Technology, v.73, p.221-225, 2000. 
CYRINO, J.E.P. Condicionamento alimentar e exigências nutricionais de espécies carnívoras: desenvolvimento de uma linha de pesquisa. Piracicaba, 2000. 200p. Tese (Livre-Docência) - Escola Superior de Agricultura "Luiz de Queiroz", Universidade de São Paulo.

DAPKEVICIUS， M.L.E.; BAPTISTA， I.; NOUT， M.J.R.; ROMBOUTS，F.M.; HOUBEN, J.H. Lipid and protein changes during the ensilage of blue whiting (Micromesistius poutassou Risso) by acid and biological methods. Food Chemistry, v.63, n.1, p.97-102, 1998.

DAPKEVICIUS, M.L.E.; NOUT, R.M.J.; ROMBOUTS, F.M.; HOUBEN, J.H.; WYMENGA, W. Biogenic amine formation and degradation by potencial fish silage starter microorganisms. Internacional Journal of Food Microbiology, v.57, p.107-114, 2000.

DAS, H.K.; HATTULA, M.T.; MYLLYMÄKI, O.M.; MÄLKKI, Y. Effects of formulation and processing variables on dry fish feed pellets containing fish waste. Journal of the Science of Food and Agriculture, v.61, p.181-187, 1993.

DE SILVA, S.S.; ANDERSON, T.A. Fish nutrition in aquaculture. 1.ed. London: Chapman \& Hall, 1995. 319p.

DE SILVA, S.S.; GUNASEKERA, R.M.; GOOLEY, G. Digetibility and amino acid availability of three protein-rich ingredient-incorporated diets by Murray cod, maccullochella peelii (Mitchell) and the Australian shortfin eel Anguilla australis Richardson. Aquaculture Research, v.31, p.195-205, 2000. 
DISNEY, J.G.; TATTERSON, I.N.; OLLEY, J. Recent developments in fish silage. In: CONFERENCE ON THE HANDLING, PROCESSING AND MARKETING OF TROPICAL FISH, London, 1976. Proceedings. London: Ministry of Oversea Development, 1977. p.321- 340.

EL-SAYED, A.F.M. Alternative dietary protein sources for farmed tilapia, Oreochromis spp. Aquaculture, v.179, p.149-168, 1999.

ESPE, M.; RAA, J.; NJAA, L.R. Nutritional value of stored fish silage as a protein source for young rats. Journal of the Science of Food and Agriculture, v.49, p.259-270, 1989.

ESPÍNDOLA FILHO, A. Aproveitamento do resíduo sólido de peixe, camarão e bivalves como ingrediente de ração para aqüicultura. São Paulo, 1999. 224p. Tese (Doutorado) - Universidade Mackenzie.

ESPÍNDOLA FILHO, A.; PINHEIRO, C.R.; OKUMURA, M.P.M. Aproveitamento do resíduo sólido de peixe, camarão e bivalves como ingrediente para a ração animal. In: SIMPÓSIO BRASILEIRO DE AQUICULTURA, 10., Recife, 1998. Resumos. Recife: Persona, 1998. p.41.

FAGBENRO, O. Dried fermented fish silage in diets for Oreochromis niloticus. The Israeli Journal of Aquaculture, v.46, n.3, p.140-147, 1994.

FAGBENRO, O.; JAUNCEY, K.; HAYLOR, G. Nutritive value of diets containing dried lactic acid fermented fish silage and soybean meal for juvenile Oreochromis niloticus and Clarias gariepinus. Aquatic Living Resource, v.7, p.79-85, 1994. 
FAGBENRO, O.; JAUNCEY, K. Water stability, nutrient leaching and nutritional properties of moist fermented fish silage diets. Aquacultural Engineering, v.14, p.143-153, 1995a.

FAGBENRO, O.; JAUNCEY, K. Growth and protein utilization by juvenile catfish (Clarias gariepinus) feed dry diets containing co-dried lactic-acid-fermented fishsilage and protein feedstuffs. Bioresource Technology, v.51, p.59-35, 1995 b.

FAGBENRO, O.; JAUNCEY, K. Physical and nutritional properties of moist fermented fish silage pellets as a protein supplement for tilapia (Oreochromis niloticus). Animal Feed Science Technology, v.71, p.11-18, 1998.

FAGBENRO, O.; BELLO-OLUSOJI, O.A. Preparation, nutrient composition and digestibility of fermented shrimp head silage. Food Chemistry, v.60, p.489-493, 1997.

FAO. Animal feed resources information system. http://www.fao.org. (23 Jan. 2003a)

FAO. World aquaculture production of fish, crustacea, molluscus, etc. by principal species in 2000. http://www.fao.org. (23 Jan. 2003)

FONTAÍNHAS-FERNANDES, A.; GOMES， E; REIS-HENRIQUES， M.A.; COIMBRA, J. Replacement of fish meal by plant proteins in the diet of Nile tilápia: digestibility and growth performance. Aquaculture International, v.7, p.57-67, 1999. 
FURUYA, W.M. Alimentos ambientalmente corretos para piscicultura. In: REUNIÃO ANUAL DA SOCIEDADE BRASILEIRA DE ZOOTECNIA, 38., Piracicaba, 2001. A produção animal na visão dos brasileiros. Piracicaba: FEALQ, 2001. p.515527.

FURUYA, W.M. Digestibilidade aparente de aminoácidos e substituição da proteína da farinha de peixe pela do farelo de soja com base em proteína ideal em rações para a tilápia do Nilo (Oreochromis niloticus). Botucatu, 2000. 69p. Tese (Doutorado) Faculdade de Medicina Veterinária e Zootecnia, Universidade Estadual Paulista "Júlio de Mesquita Filho".

FURUYA, W.M.; PEZZATO, L.E.; MIRANDA, E.C.; BARROS, M.M.; PEZZATO, A.C.; FURUYA, V.B. Coeficiente de digestibilidade aparente da energia e nutrientes de alguns ingredientes pela tilápia do Nilo (Oreochromis niloticus). In: REUNIÃO ANUAL DA SOCIEDADE BRASILEIRA DE ZOOTECNIA, 38., Piracicaba, 2001. Anais. Piracicaba: FEALQ, 2001. p.1407-1408.

GODDARD, J.S.; AL-YAHYAI, D.S.S. Chemical and nutritional characteristics of dried sardine silage. Journal of Aquatic Food Product Technology, v.10, n.4, p.39-50, 2001.

GONÇALVES, J.F.; SANTOS, S.; PEREIRA, I.B.; COIMBRE, J. The use of fish silage as an ingredient for eel fingerling nutrition. Aquaculture, v.80, p.135-146, 1989.

GREEN, S. The use of fish silage in pig nutrition. Nottingham, 1984. 230p. Thesis (Ph.D.) - University of Nottingham. 
GREEN, S.; WISEMAN, J.; COLE, D.J.A. Examination of stability, and is effect on nutritive value, of fish silage in diets for growing pigs. Animal Feed Science and Technology, v.21, p.43-56, 1988.

GUZMÁN, J.M.; VIANA, M.T. Growth of abalone Haliotis fulgens fed diets with and without fish meal, compared to a commercial diet. Aquaculture, v.165, p.321-331, 1998.

HAARD, M.F.; KARIEL, N.; HERZBERG, G.; FELTHAM, L.A.W.; WINTER, K. Stabilization of protein and oil fish in silage for use as a ruminant feed supplements. Journal of the Science of Food and Agriculture, v.36, n.4, p.229-241, 1985.

HAJEN, W.E.; HIGGS, D.A.; BEAMES, R.M.; DOSANJH, B.S. Digestibility of various feedstuffs by post-juvenile Chinook salmon (Oncorhynchus tshawytscha) in sea water. 1. Validation of technique. Aquaculture, v.112, p.321-332, 1993a.

HAJEN, W.E.; HIGGS, D.A.; BEAMES, R.M.; DOSANJH, B.S. Digestibility of various feedstuffs by post-juvenile Chinook salmon (Oncorhynchus tshawytscha) in sea water. 2. Measurement of digestibility. Aquaculture, v.112, p.333-348, 1993 b.

HAMMOUMI, A.; FAID, M.; EL-YACHIOUI, M.; AMAROUCH, H. Characterization of fermented fish waste used in feeding trials with broilers. Process Biochemistry, v.33, n.4, p.423-427, 1998.

HERAS, H.; MCLEOD, C.A.; ACKMAN, R.G. Atlantic dogfish silage vs. herring silage in diets for Atlantic salmon (Salmo salar): growth and sensory evaluation of fillets. Aquaculture, v.125, p.93-103, 1994. 
HIGUERA, M. de la. Diseños y métodos experimentales de evaluación de dietas. In: MONTEROS, J.A.E. de los; LABARTA, M. (Ed.). II Nutrición en acuicultura. Madrid: Comisión Asesora de Investigación Científica y Técnica, 1987. p.291-318.

HILDSORF, A.W.S. Genética e cultivo de tilápias vermelhas, uma revisão. Boletim do Instituto de Pesca, v.22, p.73-87, 1995.

HONCZARYK, A.; MAEDA, L.S. Crescimento do pirarucu, Arapaima gigas, utilizando dieta à base de ensilado biológico de pescado. In: SIMPÓSIO BRASILEIRO DE AQÜICULTURA, 10., Recife, 1998, Anais. Recife: Persona, 1998. v.2, p.93-100.

HOSSAIN, M.A., JAUNCEY, K. Studies on the protein, energy and amino acids digestibility of fish meal, mustard oilcake, linseed and sesame meal for commom carp (Cyprinus carpio). Aquaculture, v.83, p.59-72, 1989.

HOSSAIN, M.A.; NAHAR, N.; KAMAL, M. Nutrient digestibility coefficients of some plant and animal proteins for rohu (Labeo rohita). Aquaculture, v.151, p.37-45, 1997.

HUSSAIN, R.A.K.; OFFER, N.W. Effect of folmaldehyde treatment on the degradation of acid-preserved fish silage protein in vitro. Animal Feed Science and Technology, v.16, p.297-304, 1987.

JACKSON, A.J.; KERR, A.K.; COWEY, C.B. Fish silage as a dietary ingredient for salmon. I. Nutritional and storage characteristics. Aquaculture, v.38, p.211-220, 1984a. 
JACKSON, A.J.; KERR, A.K.; BULLOCK, A.M. Fish silage as a dietary ingredient for salmon. II. Preliminary growth findings and nutritional pathology. Aquaculture, v.40, p.283-291, $1984 b$.

JOHNSON, R.J.; BROWN, N.; EASON, P.; SUMMER, J. The nutritional quality of two types of fish silage for broiler chickens. Journal of the Science of Food and Agriculture, v.36, p.1051-1056, 1985.

KOMPIANG, I.P. Fish silage: its prospect and future in Indonesia. Indonesia Agricultura Research \& Development Journal, v.3, n.1, p.9-12, 1981.

KUBITZA, F. Tilápia: tecnologia e planejamento na produção comercial. São Paulo: Degaspari, 2000. 285p.

LINDGREN, S.; PLEJE, M. Silage fermentation of fish or fish waste products with lactic acid bacteria. Journal of the Science of Food and Agriculture, v.34, p.1057$1067,1983$.

LOVSHIN, L.L. Red tilapia or Nile tilapia: which is the best culture fish? In: SIMPÓSIO SOBRE MANEJO E NUTRIÇÃO DE PEIXES, 2., Piracicaba, 1998. Anais. Campinas: CBNA, 1998. p.179-198.

LOVSHIN, L.L.; CYRINO, P.E.P. Status of commercial fresh water fish culture in Brazil. In: SIMPÓSIO SOBRE MANEJO E NUTRIÇÃO DE PEIXES, 2., Piracicaba, 1998. Anais. Campinas: CBNA, 1998. p.1-20.

MAIA, W.M.; NUNES, M.L.; FIGUEIREDO, M.J.; BRAGAGNOLO, N. Caracterização da fração lipídica de silagem de resíduos de tilápia para utilização em rações para a aqüicultura. In: SIMPÓSIO BRASILEIRO DE AQUICULTURA, 10., Recife, 1998. Anais. Recife: Persona, 1998. v.2, p.55-64. 
MAINA, J.G.; BEAMES, R.M.; HIGGS, D.; MBUGUA, P.N.; IWAMA, G.; KISIS, S.M. Digestibility and feeding value of some feed ingredients fed to tilápia Oreochomis niloticus (L.). Aquaculture Research, v.33, p.853-862, 2002.

MAINARDES-PINTO, C.S.R.; VERANI, J.R.; ANTONIUTTI, D.M. Estudo comparativo do crescimento de machos de Oreochromis niloticus em diferentes períodos de cultivo. Boletim do Instituto de Pesca, v.22, p.73-87, 1995.

MARTIN, A.M.; BEMISTER, P.L. Use of peat extract in the ensiling of fisheries wastes. Waste Management and Research, v.12, p.467-479, 1994.

MORAIS, C.; MARTINS, J.F.P. Considerações sobre o aproveitamento de sobras da industrialização de pescado na elaboração de produtos alimentícios. Campinas: ITAL, 1981. 300p. (Boletim ITAL, 3)

MORALES-ULlOA, D.F. Bioconversão de resíduos da indústria pesqueira. Piracicaba, 1994. 127p. Dissertação (Mestrado) - Escola Superior de Agricultura "Luiz de Queiroz", Universidade de São Paulo.

MORALES-ULlOA, D.F.; OETTERER, M. Bioconversão de resíduos da indústria pesqueira. Ciência e Tecnologia de Alimentos, v.15, n.3, p.206-214, 1995.

MORALES-ULlOA, D.F.; OETTERER, M. Composição em aminoácidos de silagens químicas, biológicas e enzimáticas preparadas com resíduos de sardinha. Ciência e Tecnologia de Alimentos, v.17, n.3, p.252-258, 1997.

NATIONAL RESEARCH COUNCIL. Nutrient requirements of fish. Washington: National Academy Press, 1993. 115p. 
NEETHISELVAN, N.; JASMINE， G.I.; MANIKANDAVELU, D.; VENKATARAMANI, V.K. Use of fermented fish ensilage in the diets of Etroplus suratensis (Bloch). Fishery Technology, v.38, n.1, p.43-47, 2001.

NELSON, D.L.; COX, M.M. Lehninger principles of biochemistry. New York: Worth Publishing, 2000. 145p.

NEW, M.; CSAVAS, I. Will there be enough fish meal for fish meals? Aquaculture Europe, v.19, n.3, p.6-13, 1995.

NUNES, M.L. Silagem de pescado. In: OGAWA, M.; MAIA, E.L. Manual de pesca. São Paulo: Livraria Varela, 1999. p.371-379.

OETTERER, M. Agroindústrias beneficiadoras de pescado cultivado: unidades modulares e polivalentes para implantação, com enfoque nos pontos críticos higiênicos e nutricionais. Piracicaba, 1999. 196p. Tese (Livre-Docência) - Escola Superior de Agricultura "Luiz de Queiroz", Universidade de São Paulo.

OETTERER, M. Industrialização do pescado cultivado. Guaíba: Agropecuária, 2002. $200 p$.

OETTERER, M. Produção de silagem a partir da biomassa residual de pescado. Alimentos e Nutrição, v.5, p.119-134, 1994.

OTTATI, M.; GUTIERREZ, M.; BELLO, R. Estudio sobre la elaboración de ensilado microbiano a partir de pescado proveniente de especies subutilizadas. Archivos Latinoamericanos de Nutrición, v.4, n.3, p.408-425, 1990. 
POPMA, T.; LOVSHIN L.L. Worldwide prospects for comercial production of tilapia. Auburn: Internatinal Center for Aquaculture and Aquatic Environments, 1996. 23p. (Research and Development Series, 41)

POPMA, T.; MASSER, M. Tilápia: life history and biology. Auburn: Southern Regional Aquaculture Center, 1999. 4p. (SRAC, 283)

PORTZ, L. Recentes avanços na determinação das exigências e digestibilidade da proteína e aminoácidos em peixes. In: REUNIÃO ANUAL DA SOCIEDADE BRASILEIRA DE ZOOTECNIA, 38., Piracicaba, 2001. A produção animal na visão dos brasileiros. Piracicaba: FEALQ, 2001b. p.528-542.

PORTZ, L. Utilização de diferentes fontes protéicas em dietas formuladas pelo conceito de proteína ideal para o "black bass" (Micropterus salmoides). Piracicaba, 2001a. 111p. Tese (Doutorado) - Escola Superior de Agricultura "Luiz de Queiroz", Universidade de São Paulo.

RAA, J.; GILDBERG, A. Fish silage: a review. Journal of the Food Science and Nutrition, v.61, p.383-419, 1982.

RAA, M.E.J.; NJAA, L.R. Nutritional value of stored fish silage as a protein source for young rats. Journal of the Science of Food and Agriculture, v.49, p.259-270, 1989.

RISTIC, M.D.; FILIPOVIC, S.S.; SAKAC, M.L.J. Liquid protein feedstuffs from freshwater fish by-products as a component of animal feed. Romanian Biotechnological Letters, v.7, n.3, p.729-736, 2002. 
RIVERO, L.E.; VIANA, M.T. Effect of $\mathrm{pH}$, water stability and toughness of artificial diets on the palatability for juvenile abalone, Haliotis fulgens. Aquaculture, v.144, p.353-362, 1996.

SALES, R.O. Processamento, caracterização química e avaliação nutricional da silagem da despesca da tilápia do Nilo (Oreochromis niloticus) em dietas experimentais com ratos. Campinas, 1995. 174p. Tese (Doutorado) - Faculdade de Engenharia de Alimentos, Universidade Estadual de Campinas.

SAMUELS, W.A.; FONTENOT, J.P.; ALLEN, V.G.; ABAZINGE, M.D.A. Seafood processing wastes ensiled with straw: utilization and intake by sheep. Journal of Animal Science, v.69, p.4983-4992, 1991.

SALES, J., BRITZ, P.J. Apparent and true availability of amino acids from common feed ingredients for South African abalone (Haliotis midae L.). Aquaculture Nutrition, v.9, p.55-64, 2003.

SMITH, R.R.; PETERSON, M.C.; ALEED, A.C. Effect of leaching on apparent digestion coefficients of feedstuffs for salmonids. The Progressive Fish Culturist, v.42, p.195-199, 1980.

SPYRIDAKIS, R.; METAILLER, R.; GABAUDAN, J.; RIAZA, A. Studies on nutrient digestibility in European sea bass (Dicentrarchus labrax). I. Methodological aspects concerning faeces collection. Aquaculture, v.77, p.61-70, 1989.

STONE, D.A.J.; ALLAN, G.L.; PARKINSON, S.; ROWLAND, S.J. Replacement of fish meal in diets for Australian silver perch, Bidyanus bidyanus, III. Digestibility and growth using meat meal products. Aquaculture, v.186, p.311-326, 2000. 
STONE, F.E.; HARDY, R.W. Nutritional value of acid stabilised silage and liquefied fish protein. Journal of the Science of Food and Agriculture, v.37, p.797-803, 1986.

STONE, F.E.; HARDY, R.W.; SHEARER, K.D.; SCOTT, T.M. Utilization of fish silage by rainbow trout (Salmo gairdineri). Aquaculture, v.76, p.109-118, 1989.

STOREBAKKEN, T.; SHEARER, K.D.; ROEM, A.J. Availability of protein, phosphorus and other elements in fish meal, soy protein concentrate and phytatetreated soy protein concentrate based diets to Atlantic salmon, Salmo salar. Aquaculture, v.161, p.365-379, 1998.

TACHIBANA, L. Desempenho inicial e digestibilidade aparente de nutrientes de diferentes linhagens de tilápia do Nilo (Oreochromis niloticus). Jaboticabal, 2002. 46p. Dissertação (Mestrado) - Centro de Aqüicultura, Universidade Estadual Paulista "Júlio de Mesquita Filho".

TATTERSON, J.N.; WINDSOR, M.L. Fish silage. Journal of the Science of Food and Agriculture, v.25, n.4, p.369-379, 1974 .

TOCHER, D.R.; MOURENTE, G.; SARGENT, J.R. The use of silages prepared from fish neural tissues as enrichers for rotifers (Brachionus plicatilis) and Artemia in the nutrition of larval marine fish. Aquaculture, v.148, p.213-231, 1997.

VALÉRIO, A.C.R. Elaboração de silagem enzimática de pescado como alternativa ao processo tradicional. Piracicaba, 1994. 102p. Dissertação (Mestrado) - Escola Superior de Agricultura "Luiz de Queiroz", Universidade de São Paulo. 
VANDENBERG, G.W.; DE LA NOÜE, J. Apparent digestibility comparison in rainbow trout (Oncorhynchus mykiss) assessed using three methods of faeces collection and three digestibility markers. Aquaculture Nutrition, v.7, p.237-245, 2001.

VARADARAJ, K.; KUMARI, S.; PADIANT, J. Comparisons of conditions for hormonal sex reversal of mozambique tilapias. The Progressive Fish-Culturist, v.56, n.2, p.81-90, 1994.

VIANA, M.T.; CERVANTES-TRUJANO, M.; SOLANA-SANSORES, R. Attraction and palatability activies in juvenile abalone (Haliotis fulgens): nine ingredients used in artificial diets. Aquaculture, v.127, p.19-28, 1994.

VIANA, M.T.; GUZMAN, J.M.; ESCOBAR, R. Effect of heated and unheated fish silage as a protein source in diets for abalone Haliotis fulgens. Journal of the World Aquaculture Society, v.30, n.4, p.481-489, 1999.

VIANA, M.T.; LOPEZ, L.M.; GARCIA-ESQUIVEL, Z.; MENDEZ, E. The use of silage made from fish and abalone viscera as an ingredient in abalone feed. Aquaculture, v.140, p.87-98, 1996.

VIDOTTI, R.M. Produção e utilização de silagens de peixe na nutrição do pacu (Piaractus mesopotamicus). Jaboticabal, 2001. 65p. Tese (doutorado) - Centro de Aqüicultura, Universidade Estadual Paulista.

VIDOTTI, R.M.; VIEGAS, E.M.M.; CARNEIRO, D.J. Amino acid composition of processed fish silage using diferent raw materials. Animal Feed Science and Technology, v.105, p.199-204, 2003. 
VIZCARRA-MAGAÑA, L.A.; AVILA, E.; SOTELO, A. Silage preparation from tuna fish wastes and its nutritional evaluation in broilers. Journal of the Science Food and Agriculture, v.79, p.1915-1922, 1999.

WINDELL, J.R.; FOLITZ, J.W.; SAROKON, J.P. Methods of fecal collection and nutrient leaching in digestibility studies. The Progressive Fish Culturist, v.40, p.51-55, 1978.

WOLFARTH, G.H., HULATA, G.I. Applied genetics of tilapia. Manila: International Center for Living Aquatic Resource Management. 1981. 26p.

WYK, H.J.; HEYNDENRYCH, C.M.S. The production of naturally fermented fish silage using various Lactobacilli and diferent carbohydrate sources. Journal of the Science Food and Agriculture, v.36, n.11, p.1093-1103, 1985.

XIMENES CARNEIRO, A.R. Elaboração e uso de ensilado biológico de pescado na alimentação de alevinos de tambaqui (Colossoma macropomum). Manaus, 1991. 81p. Tese (Mestrado) - Instituto Nacional de Pesquisas da Amazônia, Universidade Federal do Amazonas.

ZAHAR, M.; BENKERROUM, N.; GUEROUALI, A.; LARAKI, Y.; EL YAKOUBI, K. Effect of temperature, anaerobiosis, stirring and salt addition on natural fermentation silage of sardine and sardine wastes in sugarcane molasses. Bioresource Technology, v.82, p.171-176, 2002. 